Portland State University

PDXScholar

Summer 1-1-2012

\title{
Essex under Cromwell: Security and Local Governance in the Interregnum
}

James Robert McConnell

Portland State University

Follow this and additional works at: https://pdxscholar.library.pdx.edu/open_access_etds

Part of the European History Commons, Military History Commons, and the Political History Commons

Let us know how access to this document benefits you.

\section{Recommended Citation}

McConnell, James Robert, "Essex under Cromwell: Security and Local Governance in the Interregnum" (2012). Dissertations and Theses. Paper 686.

https://doi.org/10.15760/etd.686

This Thesis is brought to you for free and open access. It has been accepted for inclusion in Dissertations and Theses by an authorized administrator of PDXScholar. Please contact us if we can make this document more accessible: pdxscholar@pdx.edu. 


\title{
Essex under Cromwell:
}

Security and Local Governance in the Interregnum

$$
\text { by }
$$

James Robert McConnell

A thesis submitted in partial fulfillment of the requirements for the degree of

\author{
Master of Arts \\ In \\ History
}

Thesis Committee:

Caroline Litzenberger, Chair

Thomas Luckett

David A. Johnson

Jesse Locker

Portland State University

(C)2012 


\begin{abstract}
In 1655, Lord Protector Oliver Cromwell's Council of State commissioned a group of army officers for the purpose of "securing the peace of the commonwealth." Under the authority of the Instrument of Government, a written constitution not sanctioned by Parliament, the Council sent army major-generals into the counties to raise new horse militias and to support them financially with a tax on Royalists which the army officers would also collect. In counties such as Essex-the focus of this study-the major-generals were assisted in their work by small groups of commissioners, mostly local men "well-affected" to the Interregnum government. In addition to their militia and tax duties, the men were instructed to see to the implementation and furtherance of a variety of central government policies. Barely a year after its inception, a bill sanctioning the scheme was voted down in January 1657 by a Parliament unconvinced that the work done by the major-generals was in the best interests of the nation.

This thesis examines the development and inception of the major-generals initiative by the Council of State, the work the major-generals and their commissioners engaged in, and the nature and cause of the reaction to their efforts in the shires. In the years and centuries following the Stuart Restoration, the major-generals were frequently portrayed as agents of Cromwellian tyranny, and more recently scholars have argued that the officers were primarily concerned with the promulgation of a godly reformation. This study looks at the aims and work of the major-generals largely through an analysis of
\end{abstract}


state papers and Essex administrative records, and it concludes that the Council and officers were preoccupied more with threats to order and stability than with morals. Additionally, by examining the court records and work of the justices of the peace in Essex, this study shows that in regard to improving order the major-generals' work was unremarkable for its efficacy and but little different than previous law- and statuteenforcement activity traditionally carried out by local administrators. Based on this assessment of the major-generals' efforts to improve order as both limited and completely un-revolutionary, this thesis argues that the strongly negative reaction to the majorgenerals by the parliamentary class was due more to the officers' and government's encroachment on gentry power and local privilege than either the abrogation of the liberties of the people or any modest efforts to foist godliness on the shires. Religion was a major issue during the English Civil Wars, but the demise of one of the Interregnum government's most ambitious attempts to improve security in the localities was rooted not in sectarian distempers but rather in the gentry's preoccupation with keeping central government from meddling in local matters or taxing anyone in their class without parliamentary approval. 


\section{Dedication}

For Emma, in thanks for her support and her many hours of work while I produced this work of many hours.

For Sammy, who often watched sadly, holding a little book in his hand, as his father went to the library to research and write. May he one day proudly hold this one.

For Jack, who though but in kindergarten can see a painting of the man who was the defender and savior of our rights and liberties, as well as Lord of England, Ireland, Scotland, and all the dominions belonging thereunto, and say, "It's Oliver Cromwell!" 


\section{Acknowledgements}

Though produced by an individual author, each academic work is the result of the accumulated efforts of many minds. My this work has built upon the efforts of the many scholars who have dedicated their working lives to the better understanding of our past and therefore ourselves, and I hope that this work is a useful contribution to that study. First and foremost I would like to thank Dr. Caroline Litzenberger for her efforts in guiding a novice and his work through the trepidatious shoals of academic production, and for her endless support, advice, and patient listening regarding the various academic and personal trials which nearly all graduate students—including this one-seem destined to confront during their studies. One could hardly hope for a better mentor and advisor, and her retirement and departure are a great loss to the university. Thanks are due to Dr. Thomas Luckett for his illumination on a variety of issues and topics regarding early modern political and intellectual revolutions, and also to Drs. David Johnson and Jesse Locker for their participation as members of the thesis committee. It would also be remiss not to mention Drs. Barbara Traver, Rodney Koeneke, and George Armantrout who have served as excellent examples of conscientious and committed instruction who have enhanced my understanding of the various and valuable ways of engaging students in historical enquiry. I can say without reservation that thanks to these professors and the many other students and staff I have encountered over the two years that my experience as a graduate student at Portland State University has been life-changing and life- 
enhancing to a degree which is impossible to put into words. It is by walking among and studying with the many fine members of the Department of History that I have learned so much about civilization and civility. Additionally, I would also like to express my appreciation to the staff at Millar Library, without whose efforts this study of persons and places far away would have been unimaginable. All these persons together have proved beyond any doubt that higher education is an endeavor of immeasurable worth which exemplifies and perpetuates what is best in humankind. 


\section{Table of Contents}

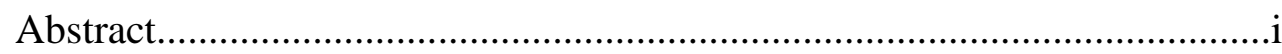

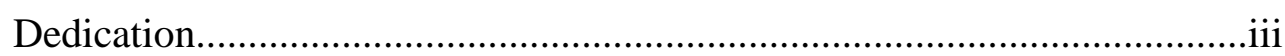

Acknowledgements.....................................................................

Abbreviations...................................................................................

Introduction........................................................................

Chapter One: Rebellion, Reversal and Reaction.................................25

Chapter Two: Into the Counties: Soldiers and Decimators......................63

Chapter Three: Order, Major-generals and the Justices of Essex...............90

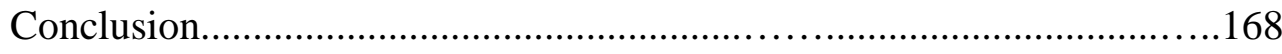

Works Cited................................................................... 181 


\section{Abbreviations}

$A$ and $O$

Abbott

CSPD

ERO, Q/SR

Josselin

Lomas

Maldon $S B$

$Q S O B$

TSP
Firth, C. H. and Robert S. Rait, eds. Acts and Ordinances of the Interregnum, 1642-1660. London: HMSO, 1911.

Cromwell, Oliver. The Writings and Speeches of Oliver Cromwell. Edited by Wilbur Cortez Abbott. Vol. 4. London: Oxford University Press, 1947.

Green, Mary Anne Everett, ed. Calendars of State Papers, Domestic Series, 1649-1660. 13 vols. London: Longmans, 1881.

Essex Record Office. Quarter Sessions Rolls, Q/SR 264-386. Seax: Essex Archives Online.

Josselin, Ralph and Alan Macfarlane. The Diary of Ralph Josselin, 1616-1683. London: Oxford University Press, 1976.

Cromwell, Oliver and Thomas Carlyle. The Letters and Speeches of Oliver Cromwell. Edited by S. C. Lomas. 3 vols. London: Methuen \& Co, 1904.

Essex Record Office. Maldon Sessions Book, 1631-1664. D/B $3 / 1 / 20$.

Essex Record Office. Quarter Sessions Rolls, Q/SR 264-386. Seax: Essex Archives Online.

Thurloe, John. A Collection of the State Papers of John Thurloe. Edited by Thomas Birch. 7 vols. London: printed for the executor of the late Mr. Fletcher Gyles; Thomas Woodward; and Charles Davis, 1742.

\section{Conventions}

The calendar year in seventeenth-century England was taken to begin on March $25^{\text {th }}$, but here it will be considered as beginning on January $1^{\text {st }}$. Thus, Charles I was executed on January 30, 1648 according to most of his contemporaries, but as referred to here he lost his head and his life on the block at the end of the first month of 1649. 


\section{Introduction}

And it is as reasonable, that as they, who by their restless designs endeavour continually to interrupt and undermine all their dearly bought liberties, which the divine hand of God hath wrought out for us, should be made instrumental (though against their wills) to conserve that they so labour to destroy. ${ }^{1}$

Commissioners for the county of Essex to the Protector, December 14, 1655

The roots of this Queen's speech really belong with Cromwell's majorgenerals. There lies the root of the Government's puritanism...I warn the Government that the British public's tolerance of puritanism runs out quite quickly. ${ }^{2}$

Andrew Rowe MP, House of Commons, May 19, 1997

In 1655, the cold winds of late autumn brought the English counties some unexpected guests: soldiers. Those soldiers were sent to the shires not to fight a pitched battle against an open enemy but for other reasons, primarily, they said, to follow the instructions of Oliver Cromwell's Council of State. In 1657, they were recalled from their posts-posts

\footnotetext{
${ }^{1}$ Commissioners for the county of Essex to the Protector, December 14, 1655, as quoted in John Thurloe, A Collection of the State Papers of John Thurloe [hereafter TSP], Thomas Birch, ed. (London: printed for the executor of the late Mr. Fletcher Gyles; Thomas Woodward; and Charles Davis, 1742), 4:317.

${ }^{2}$ Andrew Rowe MP, speech to the House of Commons, May 19, 1997, as quoted in Christopher Durston, Cromwell's Major Generals: Godly Government During the English Revolution (Manchester: Manchester University Press, 2001), vi.
} 
which would never be filled again. For centuries after they departed, those officers were said to have been tyrants sent to effect a tyranny, or arbitrary government, in the localities which abrogated the rights and liberties of Englishmen. Their presence, critics claimed, also exemplified the dictatorial and autocratic nature of government in the English Interregnum (1649-1660). ${ }^{3}$ Others have argued that the officers were sent to the counties for the purpose of godly reformation. ${ }^{4}$ But these explanations do not take into account the full scope of their work. The overwhelming drive behind the introduction of the major-generals and their assisting commissioners into the shires was the security of the nation, and they were, in fact, called the commissioners for "securing the peace of the commonwealth." to protecting what they felt were the rights and just liberties of the nation. But to understand how they came to be sent there, and why there was even an army in England at the time, one has to go back a few years before those officers arrived: the fateful year of 1642 .

A hurricane struck England. A wind began to blow which shook to its roots the very foundations of society and government. The king fled the capital. The queen fled the country. Parliament divided. The episcopacy shattered: the church split from the state. The king raised his standard; Parliament theirs. Civil War enveloped the nation and its surrounding kingdoms. On hillock, glen, and pasture father fought son and

\footnotetext{
${ }^{3}$ Durston, 3-8; Peter Gaunt, “'The single person's confidants and dependents'?: Oliver Cromwell and his Protectoral Councillors," Smith, David L., ed., in Cromwell and the Interregnum: The Essential Readings (Malden, MA: Blackwell Pub, 2003), 94-96; Anthony Fletcher, "Oliver Cromwell and the Localities," in Smith, Oliver Cromwell and the Interregnum, 136."

${ }^{4}$ Durson, 231.

${ }^{5}$ A Declaration of his Highness...for Securing the Peace of the Commonwealth (London, 1655) 1. Wing C7082.
} 
brother fought brother as castles burned, houses were pillaged, towns destroyed. Tens of thousands fell in the field. Siege after siege, and battle after battle was fought: 1642, 1643, and then: 1644. On a summer afternoon in a battle of 40,000 men on the Yorkshire moors, a cavalry commander of the wilting parliamentary side turned his "Ironsides" and smashed the Royalist rear. Oliver Cromwell would go from victory to victory until the nation—and the king—were safely in Parliament's hands. ${ }^{6}$

In 1646 the war ended, the country was whole again, and a modicum of normalcy returned. Yet Parliament was still divided. Religious and political factions within the victorious representative body wrestled for control of the monarch's person and the reins of government, and the king played the sides against one another. The environment of political let the bloody-minded into another bloody struggle. Again, war erupted throughout the nation. Again, Parliament's New Model Army carried the day in the Second Civil War. And again, the Presbyterian faction in Parliament threatened to side deal with the king without the consent of the Independents. This time, however, the army-backed Independents had had enough. New Model Army troops purged the Parliament of Presbyterians; the Rump Parliament was born. Blame for the continued factionalism and threat of war was laid on the person of the king. For sewing division he received the ultimate penalty in an act of justice and retribution that was felt in every court in Europe and truly heard around the world. King Charles I put his head on the executioner's block, January 30,1649 . That day he died, and on that day the

\footnotetext{
${ }^{6}$ For a more thorough discussion and narrative of the English and British Civil Wars, see Mark Kishlansky, A Monarchy Transformed: Britain 1603-1714 (London: Penguin, 1996); Austin Woolrych, Britain in Revolution, 1625-1660 (Oxford: Oxford University Press, 2002); Blair Worden, The English Civil Wars, 1640-1660 [hereafter ECW] (London: Weidenfeld \& Nicolson, 2009).
} 
Commonwealth was born. To much rejoicing was the republic begun, but before long, the rejoicing—and the republic—was done.

Once the chief Royalist—-the king—was dispatched and Parliament purged of Presbyterians, the army and the Independents led by Oliver Cromwell might have felt that the path to peace and settlement was all downhill. If so, they were wrong. Over the next eleven years until the restoration of the monarchy, the nation was constantly under arms and regularly under threat of either invasion or rebellion. After dispatching the king, the army turned to deal with pro-Royalist and anti-Parliament rebels in the other British nations. The New Model Army, formed as a cohesive unit in 1645 from the pieces of Parliament's other armies, defeated Royalists in Ireland (1649-50) and Scotland (1650). Cromwell and the New Model would then defeat a combined Scots-English army at Worcester on September 3, 1651, the last pitched battle in the English—and British— Civil Wars. Subsequently, various actions in the West Indies (1655) and Flanders (1658) would again occupy elements of the army. After the Battle of Worcester, the troops in the British kingdoms were primarily kept to ensure peace. With its string of victories, the army-supported government lapsed into a feeling of safety. Yet later in the decade the government and nation would be rudely awakened from its confident stupor by another sort of enemy: one which came from not afar, but nearby and inside the country.

External enemies were one thing to defeat; internal enemies another. Military victory had not eliminated many of Parliament's opponents; they were merely pushed underground. A significant portion of those who had fought for the king retired to a quiet life in the shires, and many others-perhaps the majority of those who did not support the 
government—went about their daily business without too much thought of who ruled.

But many opponents of Oliver Cromwell and the Independents wished to carry on the struggle. One way was through publishing, and from the presses flowed a great variety of seditious and critical books and pamphlets calling for resistance, including restoration of the monarchy. Some publications openly called for the assassination of the hero of Parliament's battlefield cause, Oliver Cromwell, who had taken on increasingly executive-style authority in the face of repeated failures by Parliament to function agreeably or govern effectively. Rather than being content with printed appeals for change, other opponents took measures which were more dangerous and treasonous: the fomenting of plots.

\section{Cromwell's "little invention"}

One of these rebellious schemes, planned and poorly executed by an organization called the "Sealed Knot," exploded with a pathetic fizz in March $1655 .^{7}$ Few were killed, but Cromwell, as Lord Protector, and the Council of State became very concerned about what might have been and what future, better planned attempts might do. ${ }^{8}$ To deal with the threat, they came up with what Oliver called "a poor little invention:" the majorgenerals. ${ }^{9}$ The major-generals were army officers elevated to a rank which was roughly equivalent to that of the lord-lieutenants, who had traditionally commanded the militias

\footnotetext{
${ }^{7}$ David Underdown, Royalist Conspiracy in England, 1649-1660 (Hamden, CT: Archon Books, 1971), 153.

${ }^{8}$ Barry Coward, The Cromwellian Protectorate (Manchester, UK: Manchester University Press, 2002), 5457.

${ }^{9}$ Oliver Cromwell and Thomas Carlyle, The Letters and Speeches of Oliver Cromwell, S. C. Lomas, ed. [hereafter Lomas] (London: Methuen \& Co, 1904), 2:530.
} 
and the trained bands in the counties. ${ }^{10}$ England and Wales were divided into twelve districts, and a major-general was assigned as the "commander-in-chief" in each of those sections. The work of the major-generals consisted of raising a new armed force to deal with rebellion or invasion, applying a new tax to government opponents, and seeing to a variety of ancillary tasks which largely consisted of implementing Council policies which had not previously been given much attention due to lack of manpower or laxity on the part of local authorities. One of those ancillary tasks was to assist—or perhaps direct— local government officials in reducing various types of social disorder. The majorgenerals were joined in their efforts by teams of "commissioners," local men from each county (rather than district) appointed to assist the major-generals in their various tasks. Though the major-generals had begun with great purpose and optimism, in 1657 Cromwell and his Council's "little invention" was consigned to the scrap heap after little more than a year.

Thomas Hobbes wrote, "If in time as in place, there were degrees of high and low, I verily believe the highest time would be that which passed betwixt 1640 and $1660 ., 11$ Exploring Cromwell's "little invention"-which was actually the Interregnum government's most ambitious attempt at administrative innovation-reveals much about the political and social world of that "highest time." The work of the major-generals touched on nearly every aspect of governance in the period: administration, jurisdiction, legal practice, constitutionality, social order, military power, morality, and religion

\footnotetext{
${ }^{10}$ Anthony Fletcher, Reform in the Provinces: The Government of Stuart England (New Haven, CT: Yale University Press, 1986), 282-283.

${ }^{11}$ Thomas Hobbes, The English Works of Thomas Hobbes, M. Molesworth, ed. (London: J. Bohn, 18391845), 6:165
} 
among others. Examining that work and the reactions to it reveals a good deal about the various political forces at play in the center and the countryside: the priorities, powers, and society of England in the 1650s. Writers and scholars have written on and debated the nature and impact of the major-generals" "rule" for centuries, and this study intends to contribute to that historiographical discussion.

\section{Essex: first for Parliament}

Because the major-generals were commissioned to work in the shires, to understand fully the proceedings for "securing the peace of the commonwealth" it is necessary to look closely at how the work progressed in the countryside. The focus of such a detailed examination must be fairly narrow. This study concentrates on Essex, which was and has always been one of the most influential counties in England. ${ }^{12}$ The county was bordered by London to the southwest, and as London's backyard whatever happened in London was felt in Essex and what was done in Essex was quickly heard of in London. As the seventeenth century progressed, the western part of the county became one of the first London suburbs and many of the commercial elite had homes or estates there. In some ways Essex was a sort of London annex: a spill-over area for the activities and properties of the powerful. The Earl of Essex was traditionally one of the most powerful Lords in the country, and he led Parliament's forces during the early years of the First Civil War. Robert Rich, Earl of Warwick, who was the most important and powerful patron of Oliver Cromwell, not only had significant holdings in the county but

\footnotetext{
${ }^{12}$ William Hunt, The Puritan Moment: The Coming of Revolution in an English County (Cambridge, MA: Harvard University Press, 1983), x, 87, 111-112.
} 
was listed as the primary lord on the assizes during the Interregnum. ${ }^{13}$ Various other important persons during the period were from Essex, such as republican firebrand Henry Vane and Henry Mildmay, who sat as a judge during the king's trial.

The county was prosperous and populous, counting some 100,000 to 120,000 as residents in the seventeenth century. ${ }^{14}$ The agricultural areas of the county produced mainly wheat and livestock, much of which went to supply the capital and its agriculture was largely geared toward supplying the lucrative London food market. The county was also an important area of textile production, particularly in the northwest part of the county around Colchester. Originally a Roman settlement, Colchester was both the center of the textile industry and the county's largest town, with 10,000 inhabitants. It was also the site of an eleventh-century Norman castle which contained the county's gaol, or house of correction. County administration, however, was conducted in Chelmsford. Though smaller than Colchester, Chelmsford was more centrally located in the county at the hub of the road network, which included the Great Essex Road, and it was close to London. Via the Great Essex Road, Londoners could reach the rest of East Anglia and the coast.

Maritime industry and trade were also important to the county. Some 130 harbors dotted the shoreline, with the two main ports being Maldon and Harwich. Maldon had traditionally been involved with exporting foodstuffs down the Thames to London, but that trade was in decline by the late seventeenth century. Harwich was a major port and

\footnotetext{
${ }^{13}$ N. McNeil O'Farrell, ed., Calendar of Essex Assize Files in the Public Record Office [hereafter assize files] vol. 3, 35/87-35/98. The assizes were circuit courts and will be explained in detail in the following pages.

${ }^{14}$ J. A. Sharpe, Crime in Seventeenth-Century England: A County Study (Cambridge: Cambridge University Press, 1983), 15.
} 
point of embarkation for traffic to the Netherlands. The town and its harbor were also of strategic importance during the Dutch wars and were a potential point of entry for antiCommonwealth troops during the Interregnum. ${ }^{15}$

Additionally, Essex was "first for Parliament."16 The county was a major source of financial support and troops during the Civil War, and it had long been known as strongly Puritan. ${ }^{17}$ However, in spite of its long-standing support for Parliament, much of the county strongly contested the presence of the major-generals. Analyzing the political and social conditions in Essex and the effects of the major-generals on that historically pro-Parliament and pro-Puritan county, a locality one might expect to have supported their presence and any puritanizing measures, sheds light on some of the reasons for opposition to the officers' work. Such an analysis also reveals some of the deeper social and political issues which led to the restoration of the monarchy just three years after the major-generals departed.

\section{Historiography}

Historical writing on the major-generals is usually included in works covering the years 1655-7, but there are relatively few published monographs or articles which have focused on the major-generals themselves. A recent exception is Christopher Durston's Cromwell's Major-generals: Godly Government during the English Revolution, ${ }^{18}$ which is a thorough and measured study of the program—-primarily on the national level. It leaves a variety of questions open to debate, though its overall approach can be

\footnotetext{
${ }^{15}$ Sharpe, 15-19.

${ }^{16}$ Hunt, $x$.

${ }^{17}$ Hunt, 3-5.

${ }^{18}$ Durston, Cromwell's Major-Generals.
} 
reasonably said to counter the commonplace that the negative reaction to the insertion of military commanders into the shires was the crucial factor in the growing dissatisfaction with the army-backed Commonwealth and thus largely responsible for the restoration of the monarchy. Earlier important studies of the major-generals are found in S.R. Gardiner and C.H. Firth's comprehensive multi-volume work on the Civil Wars and Interregnum, ${ }^{19}$ and a further, more detailed article written by David Wilson Rannie under Gardiner's supervision in 1895 contains the fairly standard, center-based account of the majorgenerals and their activities. $^{20}$

The Interregnum is a period relatively neglected by the historiography. Overall, the literature on the Civil War and Interregnum is severely weighted to the causes and progression of the actual armed conflict which began in 1642, often ignoring the period of the Interregnum (1649-1660) as nothing more than the sad tale of a failing dictatorial regime. The production of books on the outbreak of the "Great Rebellion" is counted by the cartload, but those on its poor stepchild, the Interregnum, tend to come in fits and spurts, and monographs are fairly rare. Single-volume studies of the Interregnum period tend to focus on specific national or religious issues, and local studies usually cover the entire rebellion period, 1640-1660, for a single county. Monographs on the localities usually include at least a cursory mention of the major-generals.

Lately, the Interregnum period has received significantly greater coverage in regard to religious history, following on from the work of John Morrill. Early in his

\footnotetext{
${ }^{19}$ S. R. Gardiner, History of the Commonwealth and Protectorate, 1649-1656, 4 vols. (New York: AMS Press, 1965); C.H. Firth and Samuel Rawson Gardiner, The Last Years of the Protectorate, 1656-1658, 2 vols. (New York: Russell \& Russell, 1964).

${ }^{20}$ David Watson Rannie, "Cromwell's Major-Generals," English Historical Review 39 (July 1895): 471506.
} 
career, Morrill challenged the prevailing — and declining — Whig and Marxist interpretations of the causes of the Civil $\mathrm{Wars}^{21}$ and has continued to do so throughout his career. His revisionist article "Religious Context of the English Civil War" redefined and reinvigorated the debates about the war's causes by famously claiming in its closing sentence, "The English Civil War was not the first European revolution: it was the last of the Wars of Religion." ${ }^{22}$ Morrill has penned several important studies on the Civil War period, including one examining the effect of the war on Cheshire up to the Restoration of $1660 .^{23}$ His overall assessment of the Interregnum is that the period was not characterized by rampant disorder, Cromwell was not a tyrant, and religious belief and religiously-based factionalism were central to governance. Morrill and Blair Worden, both now entering the later stages of their academic careers, have consistently contributed to the literature of the Interregnum, usually lending their revisionist sensibilities to countering common misconceptions about Oliver Cromwell and his governing coreligionists. $^{24}$

But there is more to revolutionary England than major-generals and religion, and there is more to its historiography as well. David Underdown has produced a study of Somerset from the Short Parliament to the Restoration (1640-1660), focused on the issue

\footnotetext{
${ }^{21}$ J. S. Morrill, The Revolt of the Provinces: Conservatives and Radicals in the English Civil War, 16301650 (London: Longman, 1987).

${ }^{22}$ John Morrill, "Religious Context of the English Civil War," Transactions of the Royal Historical Society, Fifth Series, vol. 34 (1984): 155-178.

${ }^{23}$ J. S. Morrill, Cheshire 1630-1660: County Government and Society During the English Revolution (London: Oxford University Press, 1974).

${ }^{24}$ The list of books and collections of articles edited or contributed to by Morrill and Worden are prohibitively long. Some of those most pertinent to this study are J. S. Morrill and J. S. A. Adamson, Oliver Cromwell and the English Revolution (London: Longman, 1990); J. S. Morrill, The Nature of the English Revolution: Essays (London: Longman, 1993); J. S. Morrill, Revolution and Restoration: England in the 1650s (London: Collins \& Brown, 1992); Blair Worden, ECW; Blair Worden, The Rump Parliament, 1648-1653 (Cambridge: Cambridge University Press, 1974).
} 
of the maintenance of order in early-modern England, and his work has also revealed much about Royalists during the period. ${ }^{25}$ There have been other county studies of the Civil War-Interregnum period, such as that by Anne Hughes, but as in many cases, hers focuses almost entirely on the period before $1650 .{ }^{26}$ Respected early modern scholar Austin Woolrych focused much of his work on the Interregnum, in addition to producing an 800-page survey covering the reigns of Charles I, the Civil Wars, and the Interregnum: Britain in Revolution. ${ }^{27}$ Woolrych also contributed to an important early revisionist set of essays edited by G.E. Aylmer. ${ }^{28}$ Meanwhile, David L. Smith edited a book of essays that discuss and reveal much about important religious and central government issues in the period. Smith has also written extensively on seventeenth-century Parliaments, and he and David Little produced an in-depth study of Parliaments of 1653-1658. ${ }^{29}$

A close study of the major-generals' rule in any single locality is lacking, though their work and the reaction it is said to have engendered invariably receives some mention in any study of the mid-to-late Interregnum. Many historians have written of the

\footnotetext{
${ }^{25}$ David Underdown, Revel, Riot, and Rebellion: Popular Politics and Culture in England, 1603-1660 (Oxford: Clarendon Press, 1985); David Underdown, Royalist Conspiracy in England, 1649-1660 (Hamden, CT: Archon Books, 1971); David Underdown, Somerset in the Civil War and Interregnum (Newton Abbot [UK]: David \& Charles, 1973).

${ }^{26}$ Ann Hughes, Politics, Society, and Civil War in Warwickshire, 1620-1660 (Cambridge: Cambridge University Press, 1987).

${ }^{27}$ Austin Woolrych, Britain in Revolution; Austin Woolrych, Commonwealth to Protectorate (Oxford: Clarendon Press, 1982).

${ }_{28}^{28}$ G. E. Aylmer, The Interregnum: The Quest for Settlement, 1646-1660 (London: Macmillan, 1972).

${ }^{29}$ Patrick Little and David L. Smith, Parliaments and Politics During the Cromwellian Protectorate (Cambridge: Cambridge University Press, 2007); David L. Smith, The Stuart Parliaments, 1603-1689. (London: Arnold, 1999).
} 
fall of the Protectorate as it closes or precedes their period of interest, but few have done important first-hand research, the exceptions being Woolrych and Derek Hirst. ${ }^{30}$

In the 1980s the functioning of local government and its courts in early modern times began to receive a fair degree of attention, with Cynthia Herrup writing on the workings of the administrative and judicial machinery in the shires. ${ }^{31}$ Anthony Fletcher has studied local government in the Stuart period extensively, focusing on the growing power of the gentry. ${ }^{32}$ Unlike other counties such as Kent, which is the subject of several studies, a major study of Essex in the Interregnum period is lacking. But J. A. Sharpe focused closely on Essex for his social history of crime in the seventeenth century, which includes the period of the Interregnum, as did Keith Wrightson, whose work has focused in great detail on aspects of social history in Essex. ${ }^{33}$ Essex Record Office historian Hilda Grieve contributed to the literature on Essex through the history of Chelmsford, the county seat, though much of her work applies to the rest of the county's history. ${ }^{34}$ One of the aims of this study is to add to the historiography on both the major-generals and their impact on the localities in the period, as well as examining the functioning of local government in Essex during the Interregnum. Part of the examination includes a

\footnotetext{
${ }^{30}$ Derek Hirst, England in Conflict, 1603-1660: Kingdom, Community, Commonwealth (London: Arnold, 1999); Austin Woolrych, "Last Quests for a Settlement, 1657-1660," in Aylmer, The Interregnum. 183204.

${ }^{31}$ Cynthia B. Herrup, The Common Peace: Participation and the Criminal Law in Seventeenth-Century England (Cambridge: Cambridge University Press, 1987).

${ }^{32}$ Fletcher, Reform; Anthony Fletcher, Sussex 1600-1660: A County Community in Peace and War (Chichester, Sussex: Phillimore, 1980).

${ }^{33}$ J. A. Sharpe, passim; K. E. Wrightson, The Puritan Reformation of Manners With Special Reference to the Counties of Lancashire and Essex, 1640-1660 (unpublished PhD thesis, Cambridge, 1973); Keith Wrightson "Two Concepts of Order: Justices, Constables and Jurymen in Seventeenth-Century England," in John Brewer and John A. Styles, eds., An Ungovernable People: The English and Their Law in the Seventeenth and Eighteenth Centuries (London: Hutchinson, 1980), 21-46.

${ }^{34}$ Hilda E. P. Grieve, The Sleepers and the Shadows: Chelmsford, a Town--Its People and Its Past, 2 vols. (Chelmsford: Published by the Essex County Council in association with the Chelmsford Borough Council, 1988).
} 
discussion of the close connection between morality and order, and this thesis argues that the major-generals and those who sent them into the localities were more concerned with security—or social order-than morality.

\section{Sources}

The primary sources for this study are divided into two categories: those of central government and those created by local government in Essex. The sources related to central government show the progress of and attitudes surrounding the Major-generals initiative, the measures taken from the center to direct matters in the localities, and the interactions between central and local government. The local documents show the workings and priorities of JPs in the county of Essex prior to and during the tenure of the major-generals in the county. The essential central government records for this study are the Calendars of State Papers, Domestic Series and the papers of John Thurloe, Cromwell's Secretary of State and intelligence chief. Particularly as there are no council minutes during the period, these sources are the best available that reveal the ideas, attitudes, and actions of Oliver Cromwell and the Council of State. Also used are various printed declarations of the Council of State, which announced and disseminated news of government policy. Additionally, Acts and Ordinances of the Interregnum, Statutes of the Realm, and the printed handbook for JPs, Countrey Justice, allow an examination of the development and priorities of government policy through the law. The Writings and Speeches of Oliver Cromwell show what the great general and eventual Lord Protector said and to some degree thought, though because he was no diarist there is limited evidence of his private feelings and opinions. A variety of commentaries of national 
figures such as Edmund Ludlow and Lucy Hutcheson are useful as well, though their anti-Protectorate bias means they require careful interpretation. Also, the Parliamentary Diaries of Thomas Burton reveals the debates in Parliament regarding the major-generals. One important local source, which includes commentary on national issues, is the Diary of Ralph Josselin, written by a Puritan clergyman of Earls Colne, Essex who lived through and commented on the Civil Wars, Interregnum, and even the post-Restoration world. The bibliography and footnotes in the subsequent chapters of this thesis provide detailed references to the above- and below-mentioned works.

Beyond Josselin's work, the best available sources about what happened in the localities are the proceedings of the local judicial and administrative courts. The records available and used here are: the Quarter Sessions Order Book for the quarterly general meeting of Essex justices, which records much of the business of the justices but only rarely includes judicial punishments; the Essex Quarter Sessions Rolls, which give numerically greater though often very cursory details of crimes or order violations brought before the justices, and are available on-line via the Essex County Council's website; the General Sessions Book for the town of Maldon, an entirely hand-written, untranscribed source in which much of the town's administrative business and some judicial actions were recorded; and the typescripts of the Essex sessions of the assizes, biyearly circuit courts where the most serious cases were tried-though less serious matters could be addressed in those sessions as well. ${ }^{35}$

Local government records require a somewhat different approach to that used in reading state papers. At the national level, Cromwell and the Council of State frequently

\footnotetext{
${ }^{35}$ Information regarding the primary sources can be found in the notes below and the bibliography.
} 
explained what they were doing and why, and commentary sources assist in

understanding the context and impact of their actions. But in the localities-again, specifically Essex_little commentary on or explanation of the practices and actions of local authorities has survived. Thus, a different approach to reading_or reading intothese sources is required. The methodology in this study is modeled on the work of a variety of other scholars, most notably Cynthia Herrup and J.A. Sharpe. ${ }^{36}$ Both social historians applied quantitative and qualitative methods, and both methods will be applied here-through with an emphasis on the latter. Rather than concentrating on observing and analyzing statistical patterns, for this study it is more realistic, interesting, and telling to examine specific cases. The analysis derived from using those methods will provide insight into social disorder in the 1650s and how authorities (local JPs or major-generals) addressed it.

The court records reveal levels, as well as types, of crime and disorder. Those records must be used with significant qualifications so that unwarranted assessments are avoided. John Morrill and John Walter have commented that "Measuring disorder is at the best times a difficult (and even questionable) exercise," 37 and looking at the court records does not provide an absolute look into the dangerousness or lawlessness of a society for a variety of reasons. Not only are records spotty, difficult to decode, inefficiently kept, and somewhat prone to error, but they show only the matters brought to court. The records of any particular county sessions or assize actually only detail a

\footnotetext{
${ }^{36}$ Herrup, 7-10, 25-66; Sharpe, 3-14; particularly for discussion regarding the difficulty in measuring levels of disorder also see Anthony Fletcher and John Stevenson, eds., Order and Disorder in Early Modern England (Cambridge: Cambridge University Press, 1985), 27-30.

${ }^{37}$ John Morrill and John Walter, "Order and Disorder in the English Revolution," in Fletcher and Stevenson, 137.
} 
small number of cases for theft, for example, when there must have been hundreds or perhaps thousands of thefts per year per county, many of which, whether reported to a local constable or not, were impossible to prosecute or thought not worth the effort to pursue. $^{38}$

Additionally, it is important to note that justices of the peace certainly did not hunt out crimes, instead usually just responding when matters were brought to their attention by members of the community. Thus, crimes with no accuser or no victim do not appear in the court records. Thus, almost all offenses which were reported required someone interested enough to produce a perpetrator and evidence of the crime. That interested person could be a victim, a bystander, or in some cases, a lower-level administrative appointee, such as a constable, church warden, or bailiff. In any case it was invariably an amateur, since those involved in the justice system were either volunteers or those "pressed" into duty on a rotating basis. It is also difficult to determine relative levels of different crimes. Some offenses, such as homicide, were much more likely to be investigated and prosecuted, as were bastard births which produced children who become wards of the parish. Therefore, based on a few dozen or even a few hundred court cases, we cannot reasonably proceed to make vast or exacting statistical assessments of the level of criminality or disorder in a culture.

For all of those reasons, the information found in court records must be carefully handled. But if properly qualified, a variety of evaluations can be made based on the information they provide. For example, where appropriate we can connect changes in

\footnotetext{
${ }^{38}$ D. H. Allen, Essex Quarter Sessions Order Book, 1652-1661 [hereafter QSOB] (The Essex County Council, 1974), xx; Essex Record Office [hereafter ERO], Quarter Sessions Rolls, Q/SR 361-381 (Seax: Essex Archives Online).
} 
matters brought before the courts to changes in the wider society. One possible cause for an increase in the reporting of a particular offence — such as highway robbery—could be an increase in that behavior in the society at large. But there could be other reasons as well. Particularly regarding sudden or short-term changes, changes reflected in the court records could also be the result of changes in enforcement practices. Thus an increase in prosecutions of highwaymen could be the result of increased governmental concern for or intolerance of that offence, leading to greater enforcement, rather than a real increase the incidence of that crime. In any case, determining the causes of changes in the court records requires careful examination.

\section{Courts and Elites: Justices of the Peace}

Court records have a kind of simple beauty when compared to commentary sources. In the latter, facts are often obfuscated or put in doubt by the highly biased opinions of the commentator, who has often selected the information he provides because of his personal agenda or point of view. Because of these biases, using commentary sources always entails separating distorted opinion from fact. Court records, on the other hand, reveal in a fairly economical manner what men and women did, and any opinion is not usually that of an individual scribe or recorder but rather a reflection of the views and mores of society. So rather than providing the view of an individual, these records represent a collective "opinion" or judgment by members of society by that society itself.

It bears remembering, however, that who is judged and how they are judged is not determined by all members of society. Those in authority determined what offenses came to the attention of the courts and how they were resolved. "The reaction of the first 
tiers of local authority, constables, clergymen, JPs ... might be critical in determining whether 'disorderly' offences were proceeded against or recorded at all." ${ }^{\text {"39 }}$ Thus, an offence was only an offence if so determined by the judges' discretion. And in the seventeenth century those judges — the justices of the peace, or JPs—came from not from the common people but rather the local social elite. ${ }^{40}$

The JPs were the leaders and masters of the counties. It was the responsibility of the justices to "keep the peace," or keep the county in good order, using the judicial powers bestowed upon them. They were also responsible for enforcing parliamentary statutes and Council directives. Members of Parliament, or MPs, were usually taken from this group and were generally the primary figures on the bench. This was certainly the case in Essex in the 1650s, where MPs Sir Richard Everard, Sir Thomas Honywood, Sir Henry Mildmay of Graces, and Sir Thomas Bowes presided when they were not sitting in Parliament. They were joined by ten to twenty-five other JPs, who the crown appointed by central government from the ranks of the most prominent citizens and landowners in the county. ${ }^{41}$ They met at the county quarter sessions of the peace: quarterly meetings of the justices. Unofficially called the "parliaments of the shires," which were social as well as political occasions, it was largely at these meetings that the justices administered the counties and judged those who violated the "common peace."

\footnotetext{
${ }^{39}$ Fletcher and Stevenson, 30.

${ }^{40}$ Herrup, 7-8, 42-66, 59-85; Fletcher, Reform, 5-19, 87-115; Fletcher and Stevenson, 16-17; Sharpe, 1936. The discussions in this section regarding the workings of local justice are informed by these works, and further information on the nature of local justice and administration can be found within those works and subsequently in this one.

${ }^{41} Q S O B$, xxxii-xli.
} 
In their judgments, the justices expressed the collective conscience and consciousness of the ruling "order" of a particular county—and to some extent the nation. That collective opinion is reflected in their decisions and actions as members of the various courts over which they presided. JPs' manner of enforcing those statutes and directives reflects the attitudes of the local gentry class toward central government and its policies, and how the attended to business reflected not only changes in the social and political environment but changes in the justices' attitudes and concerns over time. Therefore, court records are valuable to this study not only because they reveal much about what was worrisome or dangerous for the common people of the nation or a particular county, but they also indicate even more strongly the priorities and preoccupations of the governing authorities. If a matter was thought important by a county's elites, its JPs judged accordingly at the sessions.

\section{Chapter summaries}

Chapter one discusses Cromwell's "little invention," which was conceived at the center in reaction to trouble in the localities. During a year of great difficulty for a government which ruled during a period of great instability, the plan to use army officers to improve the security of the Commonwealth was hatched. That idea consisted initially of adding horse militias to the defensive capability of the nation. But as the plan progressed, other tasks were assigned to the major-generals until their remit became a plethora of mostly civil government matters, including a tax on those who were thought to constitute a threat to the state. Finally, in October of 1655, the Council issued a 
declaration explaining its reasons for asking army officers to improve security in the countryside, after which the men assumed their posts and began to carry out their orders.

Chapter two focuses on that work and how it progressed. A close reading of the major-generals' and commissioners' correspondence with central government reveals their priorities and attitudes toward their work, as well as their feelings about local officeholders. The major-generals commenced their tasks with some degree of trepidation, largely because they were inexperienced in local government administration, though enthusiasm was not lacking. Once they had arrived in the counties, they immediately began setting up the new militias. Troops, however, are rarely free, and to pay for the part-timers the government would resort to a decimation tax which took a tenth of the income from land held by the wealthiest members of the Royalist "party." This work was often found to be quite difficult and the major-generals' efforts met with varying degrees of success. Collecting the tax and their other tasks aimed at improving order in the towns and counties also brought them into contact with local officials.

The local authorities with whom they had contact were sometimes members of the town councils, but in pursuing a more orderly nation the major-generals would also be required to work with the Justices of the Peace, or JPs, who were local notables of the gentlemanly, or gentry class (or social order) that ruled the shires and from whose ranks the members of Parliament were chosen. How the major-generals interacted with those local officeholders reveals a good deal whether they were there to cooperate with local authorities or brush them aside in the name of establishing absolutist-style arbitrary government. 
No action is without a reaction, and no effect is without a cause. Chapter three examines the actions of, and reactions to, the major-generals and their commissioners by looking at their impact on local justice and administration. Social order was a constant preoccupation for those in power during the early modern period, and following a decade of open war it seems that concern about disorder-if not disorder itself-was fairly prevalent. The major-generals were sent to make the counties safer, and part of their remit to improve security dealt with reducing disorder. The major-generals worked to reduce the general level of disorder by confronting those engaging in disorderly behavior and bringing them to account, which was done through the local courts which were presided over by the local JPs. Examining local records of the county of Essex reveals the type and extent of social disorder as well as various means exercised to control it.

Some writers have argued that one of the main aims of the major-generals' initiative was to effect a moral or "godly" reformation on the localities. Chapter three also examines the extent to which the officers focused on such a reformation. Those who felt the effects of the attempt to improve social order were the common people, and the cases in the court records paint a fascinating picture of what life was like for the country people of the Essex. County life included elections, and the chapter concludes by discussing the connection between the results of the parliamentary elections of 1656 and the presence of the major-generals. It was those members returned to Parliament in 1656 who would be responsible for bringing the work of the major-generals in the localities to a clear end. Yet the nature of the officers' rule - whether arbitrary or "godly" - has been 
debated ever since they left the localities in 1656. Analyzing and clarifying the purposes and work of the major-generals is focus of this thesis.

\section{Clarification of terms}

The subsequent discussions will benefit from a brief attempt to clarify terms regarding the different offices, initiatives, and even periods addressed in this thesis, many of which are very similar and sometimes overlapping. Therefore, some introductory explanation seems advisable. As is probably obvious, the Civil War period refers to the two decades spanning 1640-1660. The Interregnum (1649-1660) refers to the years between the death of Charles I (1649) and the return of Charles II, known as the Restoration (1660). The Commonwealth refers to the English, or nominally British, state during the Interregnum, which was republican in theory at least. The Protectorate (16531658) is a term used by historians for the period when Lord Protector Oliver Crowell or his son Richard wielded a power not unlike that of a monarch based on the authority of the Instrument of Government (1653), England's first written constitution, and then the Humble Petition and Advice (1657). The Council of State was the primary Interregnum governmental council of around fifteen members by which most non-Parliamentary government decisions were made, and through the Instrument it acted as if it legitimately possessed Parliament-like powers when Parliament was not in session. The Council's seat was at Whitehall, whereas Parliament sat at Westminster.

"Major-generals" refers to the high-ranking officers sent by the Council of State and Lord Protector into the localities. They were assisted in each county by some "commissioners for securing the peace of the Commonwealth," who will be referred to as 
"commissioners." "Major-generals" will often be used to refer collectively to the two groups, according to historiographical convention and the desire to eliminate unnecessary verbiage, although the terms, "commissioners" and "officers" will substitute for "majorgenerals" when appropriate and clear from context to avoid irritating verbal redundancy.

There were actually many types of commissioners during the Civil Wars (such as for the excise tax, compounding, etc.), and if mentioned they will be mentioned with their full titles (e.g. commissioners for the excise) or special names (e.g. excise men, compounders, etc.). "Commissions" generally refers to the offices the major-generals and commissioners held or to the specific document which gave them their power. This is different from the "commissions of the peace," which refers to the quarterly list by which central government installed local officials in their offices, such as Justices of the Peace, or JPs. When the "commission of the peace" is discussed it will be referred to by its full name, and the Justices of the Peace will usually be referred to as "JPs," according to historiographical convention. Others who worked in local administration and justice will be referred to by their title: mayor, sheriff, bailiff, burgess, alderman, JP, constable, etc., or referred to collectively as "local officials." Councils other than the Council of State, such as the Coventry or Maldon Town Councils, will be referred to by name or an appropriate abbreviation. The term "councilmen" only ever applies to the members of town councils. 


\section{Chapter One}

\section{Rebellion, Reversal and Reaction}

That which plainly seeks the destruction of the Being of this nation, is out of doubt the endeavor and design of all the common enemies of it, I think truly it will not be hard to find out who those enemies are. ${ }^{42}$

Lord Protector Oliver Cromwell, Speech at the opening of Parliament, September 17, 1656.

At the beginning of 1655, following the dissolution of the First Protectorate Parliament, there was uncertainty regarding the direction of governmental power. But there was none regarding the power of the New Model Army. In England, Ireland, and Scotland, its force had swept all before it and united the British realms as no monarch ever had. On the basis of the army's might, kings on the continent and captains on the sea trembled at the power of England and its Lord Protector. The exiled Stuart court's secretary wrote "foreign Princes and States...basely crouch and creep to such an upstart fellow and rebel as Cromwell, who keeps them all in awe, and makes them, at a distance, and even in their

${ }^{42}$ Oliver Cromwell, The Writings and Speeches of Oliver Cromwell, Wilbur Cortez Abbott, ed. [hereafter Abbott] (London: Oxford University Press, 1937), 4:261. 
own kingdoms, to tremble with fear of his power and displeasure." ${ }^{, 3}$ Yet all was not well. Over the course of the next year a variety of enemies and events would threaten the security of the nation and bring about an alteration in the government's perception of what was required to safeguard itself and its people. These concerns would lead to important policy changes — experiments, really_designed to secure the land. The most "revolutionary" one, which is the subject of this thesis, was the "commission for securing the peace of the Commonwealth," referred to by Cromwell as a "poor little invention" and by others as the "rule" of the major-generals. This chapter discusses the political and administrative background of the mid-to-late Interregnum, the events and circumstances that led the government to reevaluate its attitude toward security in the localities, and the progression and implementation of a new set of policies - to be implemented by majorgenerals-designed to ensure the security of the nation by preventing rebellion and decreasing disorder in English counties and towns.

\section{Parliamentary failure and the establishment of the Protectorate}

The English government in early 1655 was the heir to the Parliamentary cause which had defeated Royalist forces in the Civil Wars and established a republic under the name of Commonwealth following the execution of Stuart king Charles I in 1649. Yet the government of 1655 was but the shattered remains of many parliamentarians' hopes. Crippling factionalism within the Long Parliament during and after the Civil Warswhich had worsened dramatically in the years before the king's trial and execution-and the resulting inability to obtain workable consensus within the Long, "Rump," and

\footnotetext{
${ }^{43}$ Mary Anne Everett Green, ed., Calendars of State Papers, Domestic Series, 1649-1660 [Hereafter CSPD] (London: Longmans, 1881), 8: 221.
} 
Barebones Parliaments brought the republican experiment an end. ${ }^{44}$ In each case, without foreign enemies to unite it Parliament turned to devour itself. Government was left in the hands of the last man standing, Oliver Cromwell, Lord General of the New Model Army and hero of the non-Presbyterian Puritan cause. Following the parliamentary discord and disorder which threatened to spread to the entire nation, it fell to Oliver Cromwell, his remaining parliamentary supporters, and the officers of the New Model Army to make non-monarchical government function for the good of the nation and the "saints" whose sacrifice in blood had secured the rights and liberties of Englishmen after years of successive wars against the supporters of a "popish" king. ${ }^{45}$ Before Cromwell took control, the English revolution was disintegrating into the sort of disorder which might have threatened to reignite the Civil Wars. And though he had no desire to rule as a dictator, the task fell to him and his fellows to bring the nation together for the sake of safety and security. ${ }^{46}$ The process by which that authority fell to Cromwell determined his relationship with parliament during his years at the helm of state.

Oliver had won his power and prestige as a battlefield commander first in the Civil Wars and then by bringing Scotland and Ireland to heel by force of arms. Following the battle of Worcester in 1651—-the Lord General's last in the fieldCromwell felt secure in the Lord's blessing, saying that he had received his "crowning mercy" ${ }^{47}$ from God in this final defeat of his opponents and Charles Stuart, heir of

\footnotetext{
${ }^{44}$ Kishlansky, Monarchy Transformed, 171-185; Worden, ECW, 521-527, 555-557.

${ }^{45}$ Austin Woolrych, "Cromwellian Protectorate: A Military Dictatorship?" in Smith, Cromwell and the Interregnum, 88.

${ }^{46}$ Woolrych, "Cromwellian Protectorate, 65.

${ }^{47}$ Hirst, England in Conflict, 267.
} 
Charles I. ${ }^{48}$ Cromwell believed that God had allowed him to definitively crush his enemies so he could get on with the business of returning to Englishmen their rights and liberties, and governing with the support of Parliament. ${ }^{49}$ A commonwealth had been established. Unfortunately, the commonwealth Parliaments would show themselves unable to function productively. Men brought together in the name of good governance and reform turned against one another, arguing over religion and endangering the security and stability of the state with their negligence, concern for trivialities, and backbiting. After the members of the Rump Parliament turned on each other and reneged on their promise to dissolve after sitting for fourteen years, Cromwell turned on them. He entered the chamber, shouting "you are no Parliament," called the speaker a "whoremaster," and dissolved the dangerously querulous body. ${ }^{50}$ Two months later a nominated Parliament, later called "Barebones" after one of its members Praise-God Barbon, had the same flaws as previous parliaments, though its members had been hand-picked for Godliness and loyalty to the Puritan cause. ${ }^{51}$ Too fractious to function, a group of its members handed authority back to Cromwell in an unprecedented Parliamentary self-dissolution on December 13, $1653 .^{52}$ Parliament could not operate even as a Parliament, much less an executive Council of State.

Without a Parliament for legislation or to approve taxation, Oliver Cromwell and the council set about ruling by other means. A debate evolved around whether rule by

\footnotetext{
48 The monarchy had been abolished by act of Parliament in 1649, so Charles Stuart, who would eventually become Charles II, was officially no more than a private citizen at the time.

${ }^{49}$ David L. Smith, "Introduction," in Cromwell and the Interregnum, 2-3.

50 The anecdote of the expulsion of the Rump Parliament is repeated in numerous works including Francios Guizon, The Life of Oliver Cromwell (London: Macmillan, 1899) 211; also in Kishlansky, 187-189.

${ }^{51}$ Hirst, England in Conflict, 279-282.

${ }^{52}$ Hirst, England in Conflict, 258, 272-278.
} 
representative body or single person would be best. A compromise emerged. The government's authority would thenceforth be based on The Instrument of Government, a written constitution created by thirty-four-year-old Major-general John Lambert, which allowed the Council and Protector to act much the same way that monarchs had acted between Parliaments. Two days after the Barebones was dissolved, the Instrument was adopted by the fifteen-member council and Cromwell was installed on its authority as Lord Protector for life. ${ }^{53}$ The council-plus-Protector attended to crucial, previouslyneglected matters, and under the combined authority of the Instrument, plus prior statute, and ordinances, which had been used by Parliament when it was at war with the king, the government began to run smoothly for the first time in years. ${ }^{54}$ Yet triennial, five-monthlong parliaments were guaranteed by the new constitution, and Cromwell himself strongly believed that elected Parliaments were essential. ${ }^{55}$ But when the first Protectorate Parliament was called, it proved as unable as the preceding Commonwealth parliaments to attend to its business. The fractious bunch immediately challenged the Instrument and again seemed likely to undermine the legitimacy of the government, which in turn might lead—as it had in 1648 following Parliamentary squabbles—to further Civil War and bloodshed. After five months, the minimum sitting time required by the Instrument, the Parliament was dissolved in January 1655 without passing a single bill. ${ }^{56}$ The business of government was again left to Oliver and his council, which

\footnotetext{
${ }^{53}$ C. H. Firth and Robert S. Rait, eds., Acts and Ordinances of the Interregnum, 1642-1660 [hereafter $A$ and O] (London: HMSO, 1911), 2:813.

${ }^{54}$ Gaunt, 100-104.

${ }^{55}$ Gaunt, 101-102.

${ }^{56}$ Coward, 41-47.
} 
propagated healing policies rather than attempting to function under the unworkable parliamentary system.

\section{Pax Cromwell}

Despite discord at Westminster, during the early 1650s the countryside was largely free of armed conflict. After the defeat at Worcester in 1651, organized military resistance in the British Isles ended. ${ }^{57}$ Large concentrations of English troops in Scotland and Ireland, 23,000 and 19,000 respectively, kept order. In England and Wales, where 11,000 troops of the New Model Army were still under arms, the state stood without serious opposition. The largest concentration of forces, some 3000, was in London, with the rest in regiments spread throughout the relatively complaisant countryside. ${ }^{58}$ The nation had had its final opportunity to fight for the king by joining Charles Stuart and the Scots at Worcester, but few Englishmen had joined the fight. ${ }^{59}$ In the counties, order was maintained by the normal apparatus of local justice administered by the traditional elites, minus those who had chosen exile or been excluded for their factional politics. ${ }^{60}$ And however they were affected toward the Protector, most Englishmen generally seemed happy to enjoy the return of peace and liberty (after the wars fought against the preceding “popish tyranny” of Charles I, Archbishop William Laud, and the Earl of Strafford), or at least to retire to a life of private affairs. This was a period of "healing and settling" in the localities, during which the communities divided by the Civil War were allowed and encouraged to put their differences aside, heal their wounds, and settle back to their pre-

\footnotetext{
${ }^{57}$ Blair Worden, "Oliver Cromwell and the Sin of Achan," in Smith, Cromwell and the Interregnum, 40.

${ }^{58}$ Durston, 3.

${ }^{59}$ Woorlych, England in Revolution, 497-8.

${ }^{60}$ Hirst, England in Conflict, 282.
} 
war ways. ${ }^{61}$ Legally and officially, this policy was supported by the Rump Parliament's

1652 Act of General Pardon and Oblivion, which established

a just Setling of the Peace and Freedom of this Commonwealth; and being most desirous that the Mindes, Persons and Estates of all the People of this Nation, might be Composed, Setled and Secured, and that all Rancour and Evil Will occasioned by the late Differences may be buried in perpetual Oblivion, that so the Government now established in the way of a Free State might be complied with, and all the Members of it enjoy their Just and Ancient Rights and Liberties, and the former Commotions and Troubles end in a quiet calm and comfortable Peace. ${ }^{62}$

Whatever the disturbances at Westminster, the people seemed to prefer peace and stability, something the Protector-but not Parliament-was able to provide. ${ }^{63}$ Although religious opinion regarding the proper settlement of the national church was still divided, most traditional and mainstream religious bodies-Anglicans, Presbyterians, Baptists, Independents, and even Catholics—were content to practice quietly. ${ }^{64}$ The more radical sects were growing, but the troublesome Quakers, Anabaptists, Diggers, and Fifth Monarchists as yet presented little actual threat to government. ${ }^{65}$ The spirit of reconciliation and settling seemed to prevail even in the ordinances of central government itself: relief of poor prisoners; surveying of highways; indemnity, pardon and grace; settling of estates; prohibition of duels and cockfights; regulation of hackney coaches; and prices of wines were the domestic matters to which the council set itself in $1654 .{ }^{66}$

\footnotetext{
${ }^{61}$ David Underdown, "Settlement in the Counties, 1653-1658," in Aylmer, The Interregnum, 165-182.

${ }^{62} \mathrm{~A}$ and $O, 2: 565-577$.

${ }^{63}$ As noted above, the Rump Parliament had passed the Act of Oblivion in 1652. But considering Parliaments' failure to govern or come to productive accord, Council and Protector were left to ensure that its provisions were enforced.

${ }^{64}$ Christopher Durston and Judith D. Maltby, Religion in Revolutionary England (Manchester: Manchester University Press, 2006), 9-10.

${ }^{65}$ Durston and Maltby, 12-13; TSP, 4:151.

${ }^{66} A$ and $O, 3: \mathrm{xcv}-\mathrm{c}$.
} 
Soldiers stood on guard to support the state, but military preparedness around the country fell significantly, with a plethora of reports in 1654-5 recording the dilapidated state of fortifications and garrisons. ${ }^{67}$ Whatever active enemies England fought were fought at sea, and the Protectorate's powerful navy guarded the nation and England's mercantile interests upon the waves. The navy was a source of both power and penury, for finding ways to fund the combined forces was one of the most pressing concerns of the government during the period. ${ }^{68}$ However, those concerns did not include the expectation of armed insurrection.

\section{Rising in revolt}

It is one thing to offer healing, settling, and forgiveness to one's enemies; it is another for them to accept. During the latter part of 1654 and early 1655 , intimations of rebellion started to appear. Not enough information surfaced to raise serious concernsparticularly considering the sense of security provided by the New Model Army's record of victories $^{69}$ - but there were certainly warnings. Secretary of State John Thurloe's spy network began to register the signs of some sort of plot. The state papers record "the enemies of the peace are still restless in their designs." ${ }^{, 70}$ A report came in at the same time that enemies were moving treasure and collecting powder. ${ }^{71}$ It was thought necessary to make the regiments in the counties aware of possible danger, and in the first week of March 1655 letters were sent out informing them that something might be afoot. Ralph Josselin, Puritan clergyman and diarist of Earls Colne, Essex reported that

\footnotetext{
67 TSP, 3: passim.

${ }^{68}$ Worden, ECW, 120-1.

${ }^{69}$ Underdown, Royalist Conspiracy, 127-149.

${ }^{70}$ CSPD, 8:43.

${ }^{71}$ CSPD, 8:38.
} 
regimental commander Major Hezekiah Haynes had received letters from the council advising caution and urging wariness. Josselin was uncertain of the level of danger, but was certainly concerned. ${ }^{72}$ That week the government took extra measures to make sure troops were supplied with munitions in case something of consequence developed. ${ }^{73}$

The ensuing rebellion came to be known as Penruddock's rising. In the early morning of March 11, 1655, Sir John Penruddock led a troop of horse to the Somerset assizes, where he arrested the judges in their beds. His force was later met and quickly defeated by New Model troops from Exeter. In the North and West, other cells of the "Sealed Knot," as the conspiracy was called, rose as well. For a variety of reasons, some likely relating to the vigilance of Thurloe's intelligence network and others due to the disorganization and lack of resolve of the forces marshaled against the Commonwealth both abroad and in the country, the various episodes of rebellious disorder were dealt with easily and the rising failed completely in a few days. ${ }^{74}$ Despite various reports of further stirrings over the following weeks, no significant danger arose and there was no further skirmishing with rebels. ${ }^{75}$

The ease with which the rising was quashed seems to have at first reassured central government that the existing forces had matters well in hand. The initial reaction in the army and government was one of relief and proud triumph over their enemies. Charles Fleetwood, Lord Deputy of Ireland, wrote to Secretary Thurloe, "This signall and

\footnotetext{
72 Ralph Josselin and Alan Macfarlane, The Diary of Ralph Josselin 1616-1683 (London: Oxford University Press, 1976), 340.

${ }^{73}$ CSPD, 8:72. Militia commissioners of London were directed to raise three regiments of foot, "and as many horse as are necessary for the safety of the city."

${ }^{74}$ Underdown, Royalist Conspiracy, 151-6.

${ }^{75}$ CSPD, 8:75-114; Underdown, Royalist Conspiracy, 153-158.
} 
eminent appearance of the Lord, in so strangely scattering our enemies in England, is no other then his doings alone, and it ought to be marvellous in our eyes."76 The Council of State also expressed itself pleased that the people of the country had shown themselves so eager to defend against the Papists. ${ }^{77}$ In the following weeks the government and army remained vigilant. Post-rising interrogations of the plotters revealed that they had expected thousands more to rise in Scotland, the west, and the north, particularly around Hull, in concert with an army mutiny. ${ }^{78}$ These troops were to have been accompanied by ten thousand men or more landing with Charles Stuart, possibly in East Anglia. ${ }^{79}$ Other reports of discoveries of chests full of arms intended to be distributed around the country supported the possibility that a major nationwide threat had been at hand, and this led to a reevaluation of possible future dangers. ${ }^{80}$ Thus the pre-rising anxiety, which had given way to relief and jubilation as it was overcome, now returned with the realizationpossibly exaggerated — of what might have been.

\section{Wariness at Whitehall}

Judicial commissions were quickly dispatched to mete out justice to the rebels. ${ }^{81}$

Justice moved swiftly, partly out of concern for possible future attempts, be they followon rebellions or attempts to rescue the rebels from justice. ${ }^{82}$ Eventual punishment varied, but there were a fairly small number of executions compared to the number of those

\footnotetext{
${ }^{76}$ TSP, 3:305. Fleetwood also wrote, "The very poore Tories much lifted up by hopes of the enemies success in England. There were some of late runne into rebellion," indicating fears that rebellions of the sort could spread beyond England.

${ }^{77}$ CSPD , 8:43, 73-88.

${ }^{78}$ CSPD, 8:250.

${ }^{79}$ CSPD, 8:98, 110, 103.

${ }^{80}$ TSP, 3:95, 98.

${ }^{81}$ CSPD , 8:112, 114, 116.

${ }^{82}$ CSPD, 8:106, 112, 117-118.
} 
released on bond and a promise not to act against the government. Only about fifteen of the rebels, including Penruddock, met their deaths on the scaffold. Some were transported to the colonies, but most were released on bond or a promise of future good behavior. ${ }^{83}$ Though the rising had generated considerable resentment in government circles, the immediate wrath of justice was fairly contained.

Most of the rebels were released, but the nation as a whole became suspect. Not much had actually changed in the localities, but at Whitehall this was certainly not the case. The realization of under-assessed past danger transformed into a perception of a persistent threat which, along with other contemporaneous political developments, would cause the government to rethink its lax attitude toward security in the localities. Measures were taken, though initially they were quite mild. In addition to the unexceptional recourse to justice, the government response consisted of a variety of fairly standard measures. Concern was shown toward the coastal areas where foreign troops could land, such as Harwich, Essex, and a request was sent to East Anglia to watch for activity such as the smuggling of men and arms into the country. ${ }^{84}$ The intelligence network of Secretary John Thurloe seems to have 'pricked up its ears' significantly, resulting in increased investigations and awareness of instances of seditious talk. Not only was the government concerned about rebellion and assassination, but it was also concerned that the people knew it was afraid of both. ${ }^{85}$ Ruth Whisken gave evidence that one Christopher Emerson had said the

\footnotetext{
${ }^{83}$ Kishlansky, 210; Woolrych, Britain in Revolution, 210-12.

${ }^{84}$ CSPD, 8:46.

${ }^{85}$ Morrill and Walter, 147, 149-50.
} 
Protector was a rogue, and a rascal, and a blood-sucker; and he would have his throat cut and his head cleft ere long; and wore two pistols in his pocket, and was afraid of every dogg that barked, and he should have his throat cut by Michelmas day. ${ }^{86}$

The suggestion was that Cromwell—and thus the government—walked in constant fear of their lives. A government which doubted itself was unlikely to inspire much confidence in its own people or supporters. Faith in the government by the people was an essential precondition of the government's survival, and as two noted scholars of the period observed, "The regimes of the 1650s survived because they had the perceived power to maintain order." ${ }^{, 87}$ Something had to be done about the perception of disorder before that public perception of faltering power undermined the regime's tenability.

Before long the Council of State began to consider more serious measures to address what were thought to be common causes of insecurity. A variety of measures were progressively enacted to bring the Cavalier party and other potential enemies under control. An April $24^{\text {th }}$ proclamation was issued announcing an ordinance for an oath of abjuration of "Popery" for the "speedy conviction of Popish recusants" and priests. All justices of the peace and other administrative officials were empowered and required to administer it to those suspected of popish practices, and any refusing were to have twothirds of their estates sequestered. This was done because the lack of enforcement of recusancy laws had "induced many to embrace popery." 88 The act targeted Catholics specifically and so seems religiously motivated, but rebellious, openly-practicing

\footnotetext{
${ }^{86}$ TSP, 4:55.

${ }^{87}$ Morrill and Walter, 163.

${ }^{88}$ CSPD, 8:139-140.
} 
Catholics were a primary threat to the state. ${ }^{89}$ Also mentioned in the proclamation were the "priests and Jesuits" who were thought to roam the countryside and thus constitute a threat to public security. ${ }^{90}$ Yet despite this extra effort at surveillance, to those at the center the country seemed ever to threaten more disorder, and not only because of the Royalists. Cromwell wrote to Fleetwood, "The wretched jealousies there are amongst us, and the spirit of calumny turns all into gall and wormwood." ${ }^{.91}$

Yet there were reasons to be hopeful. During the rising the standing army had not been required to carry the entire weight of defense. Around the country, troops of men had spontaneously risen to support the government, bringing one officer to declare of the Royalists, "The country set against them." ${ }^{, 2}$ This unexpected response of loyal locals had been the pleasant silver lining within the dark cloud of armed rebellion. ${ }^{93}$ The knowledge that the country would rise to defend the nation from threats of rebellion must have been heartening to central government. The Protector noted as much in a letter to the militia commissioners of Essex. "The readiness of the honest people to appear has much encouraged us, and discouraged the enemy...We thank you for your zeal and forwardness." ${ }^{94}$ A letter from Worcester reached Thurloe saying, "Here are many honest hearts and hands entire to the present government...thought it theyr duty to appeare...if his highness shall thinke fit to command any thinge of the inhabitants of this county, his

\footnotetext{
${ }^{89}$ William Sheils, "English Catholics at War and Peace," Durston and Maltby, Religion in Revolutionary England, 137-157. Catholics who practiced quietly and did not contribute to rebellion were generally left along during the period - at least those of gentlemanly orders.

${ }^{90}$ CSPD , 8:135, 139.

${ }^{91}$ TSP , 3:572.

${ }^{92}$ CSPD, 8:98-9.

${ }^{93}$ CSPD , 8:88.

${ }^{94}$ CSPD , 8:92.
} 
highness will find here many ready and cheareful servants." 95 In East Anglia, Major Hezekiah Haynes reported that he was greatly heartened by the turn out of the people and that "our recruits come in more freely than expected, and had we but moneys, men of good affection would not be wanting." 96 On the heels of these positive reports came requests for payment of those who had spontaneously come to the aid of the state-in fact, a very significant number. ${ }^{97}$ The need to pay for these unplanned levies caused some consternation at Whitehall. But they were not as expensive as the full-time army, and the troops were all too willing to disband quickly and return to their homes. ${ }^{98}$ But Haynes complained that in Essex "want of pay" was a "great discouragement" for the volunteers. $^{99}$

\section{Battered finances and the beleaguered state}

Want of pay - and of money in general-was one of the major problems of the Commonwealth and Protectorate. The Instrument of Government specified that the nation should provide enough revenue for the operation of the traditional state apparatus in addition to an army of 10,000 horse and 20,000 foot, and "a convenient number of ships for guarding the seas." ${ }^{100}$ Though the Instrument provided the ultimate basis of law during the Protectorate, it was far easier to provide a legal than a practical financial basis of support. Governmental finance in England and Western Europe was generally difficult in the seventeenth century. ${ }^{101}$ But supporting an army of tens of thousands and a

${ }^{95}$ TSP, 3:290.

${ }^{96}$ TSP, 3:253.

${ }^{97}$ CSPD, 8:149.

${ }^{98}$ CSPD, 8:149.

${ }^{99}$ TSP, 3:227.

${ }^{100} A$ and $O, 2: 820$.

${ }^{101}$ Pierre Goubert, Louis XIV and Twenty Million Frenchmen (New York: Vintage Books, 1972), 309. 
world-class Navy, which had quadrupled in size under the Rump Parliament, ${ }^{102}$ was difficult for a relatively small nation which had traditionally managed with no army at all. Charles I's difficulties with finance, which had contributed to the outbreak of the Civil Wars, would also plague the Protectorate.

The primary financial supports for the Interregnum government were the monthly assessment (to some extent a holdover from the Civil Wars), and the customs excise. Generally these sources of revenue were unpopular with taxpaers, who at times wondered aloud why the Civil Wars over "a little ship money" had been fought when the Interregnum government taxed them even more heavily without consent. ${ }^{103}$ Naval plunder, particularly of Spanish shipping returning from the colonies, was an additional source of cash. But like the trade-based excise, it was an unpredictable source of revenue for a government with predictably high financial demands. The council began working on reducing costs so that it could lower the assessment, which Cromwell hoped to reduce from $£ 120,000$ to $£ 60,000$ per month. Orders were given to reduce army garrisons from 100 to 80 men, and additional funds were allocated to pay the arrears of those leaving the army. ${ }^{104}$ Charles Fleetwood commented at the time, "Wee are put to a great straight, not knowing well what to do, being not able to continue the present army."105 The government was thus under constant financial strain. The navy commissioners reported in 1655 that General Blake's fleet, which had just returned from the Mediterranean, had not been paid for twenty months and was owed some $£ 120,000$, of which the naval

\footnotetext{
${ }^{102}$ Worden, ECW, 120-1.

${ }^{103}$ Maurice Ashley, The Greatness of Oliver Cromwell (New York: Macmillan, 1958), 317.

${ }^{104}$ Worden, ECW, 123, 135.

${ }^{105}$ TSP, 3:170.
} 
commission was able to pay only $£ 20,000$ owing to the navy's already vast debts of $£ 657,835 .^{106}$

While the state was cutting costs it was also attempting to expand England's international footprint. Foreign policy and conquest were major concerns for the government, and 1655 was a difficult year for both. Just after the rising, an English fleet and army attacked the Spanish colonies in the New World. Jamaica was taken, but their main target, Hispaniola, was not. Many perished in the vain attempt, and for the first time the New Model Army_God's instrument in beating popery—had lost. The logistical reasons for the loss were simple enough: poor quality troops consisting of raw recruits, deportees, indentured servants, and various ne'er-do-wells, rather than the motivated and disciplined troops which had swept all before them in Britain; additional contributing factors were poor intelligence on the quality of the defense, ineffective leadership, and inexperience in the hardships of tropical operations. ${ }^{107}$ The loss came as a significant blow to Cromwell and those of the Godly nation. Over the course of the Civil Wars they had come to believe that God's providence had sanctioned their victories. The army of the "saints" had repeatedly overcome difficult odds, triumphing via the mercy of the Lord when all seemed lost. God had given England to the godly in the name of liberty and right religion, and now, suddenly, the Lord had removed his sanction. On the one hand, they wondered what they had done which had brought such censure. ${ }^{108}$ On the other hand, they wondered: if in fact God had allowed them to lose in the New World where godliness was surely needed, might the same fate not befall them at home?

\footnotetext{
${ }^{106}$ CSPD, 8:381-2.

${ }^{107}$ Woolrych, Britain in Revolution, 631-4.

${ }^{108}$ Blair Worden, "Sin of Achan," in Smith, Cromwell and the Interregnum, 39-41, 49-54.
} 
Yet England did not need to look across the Atlantic to find international enemies. Just across the channel lay the nation's most dangerous opponents. First was Charles Stuart, the assumed inspiration for the recent rebellion and rallying point for those who wanted to overthrow the Interregnum government. Cromwell had beaten Charles in Scotland and again at Worcester, but the former Prince of Wales, his agents, and his peripatetic court lurked undeterred somewhere across the Channel. There was significant concern about further landings, and the Protector's admonition to keep a lookout for enemies was largely aimed at catching Stuart spies and preventing Stuart landings.

The other continental danger was from the threat of international Popery. After the rebellion and the losses in the West Indies came news of the massacres of the Protestant Waldensians in Piedmont and trouble in the Protestant cantons of Switzerland. With the Council's permission, the basket was passed throughout the nation, and the godly donated upwards of $£ 15,000$ for relief of their besieged continental brethren. ${ }^{109}$ As during the Thirty Years' War when Englishmen anxiously awaited corrantos bringing news from abroad detailing the bloody struggle against Catholicism, and then expressed their anxieties by contesting Archbishop William Laud and his Arminian innovations at home, English Protestants again felt themselves vulnerable to the arrival of Popish forces_-a dark, satanic specter from the Continent, often embodied by fears of Catholic Spain. $^{110}$

These fears were part of the prevalent millennial cosmology, which was strong with army radicals such as the Fifth-monarchists but also affected more moderate

\footnotetext{
${ }^{109}$ CSPD, 8:165, 183.

${ }^{110}$ Lomas, 2:520; Sheils, 138.
} 
Puritans as well. They believed that the devil, in the guise of the Pope, had designs to take over all of Europe and the world. Resisting these efforts was not only their pragmatic and patriotic duty; it was their mission and commission from the Lord. ${ }^{11}$ Worrying about news from Europe and fearing the end of the world, moderate Presbyterian Ralph Josselin consoled himself that even if the Popish forces took the nation it meant the coming of Christ. Fretting in his diary about those events, he consoled himself writing, "I had an apprehension I might bee reserved to see the world turned into a wilderness, and christs coming and this I eyed as a mercy."112 He certainly did not want Satan to take the world, but hoping that such a defeat would be followed by the rapture would have been a comfort in insecure times.

It was against the background of these threats, problems, and setbacks that the government contemplated measures to prevent further risings and the disorder that they believed could give birth to rebellion. What the council needed was a low-cost or no-cost force in the localities which was without anti-government factional bias. But who could they depend on to raise such a force? The army, of course, was reliable, but raising more troops too expensive. ${ }^{113}$ The traditional militia commanders were lord lieutenants, who were mostly nobles who had mostly fought with the king and could not be trusted if they were still in office. ${ }^{114}$ Local government was intact, and the Council expected JPs and sheriffs to respond to their directives and ordinances just as they had under the monarchy. But it was difficult to know from the inner chambers of Whitehall who was truly loyal in

\footnotetext{
${ }^{111}$ Worden, "Sin of Achan," 39.

112 Josselin, 145, 335-336.

${ }^{113}$ Worden, ECW, 146-7.

${ }^{114}$ Fletcher, Reform, 316.
} 
the localities, who secretly ignored government policy while protecting the interests of the anti-government "malignants." "115 Some JPs in Southampton were reported to have encouraged men not to assist in putting down the rebellion the rebellion in March-a complication the Council feared and would have wanted to preclude. ${ }^{116}$ Something else was needed: something new. That new "invention" would be the "rule" of the majorgenerals.

\section{Half-measures to secure the state}

The Council produced a variety of measures to improve security over the spring and summer of 1655 . Because councilors had many other matters to deal with as wellincluding fallout from the defeat in Hispaniola, finance, and all manner of administrative business - the major-generals' initiative was developed over the span of months. In this period a single directive or two might have indicated a fairly limited degree of interest in security, but the many measures related to security, sedition, and rebellion during the period reflect a constant preoccupation with the issue. On July $3^{\text {rd }}$ a proclamation appeared stating that all ejected ministers must "give up possession" of their livings and that all who refused conformity would be "reputed disturbers of the peace, disaffected, etc., and so proceeded against."117 This directive called for ministers who had been evicted from their livings to keep away from their old parishes or relinquish them if they had not yet done so. This might seem a purely religious matter relating to confessional policy, but some of the fringe sects were considered by all reasonable men as hotbeds of

\footnotetext{
115 "Malignant" was the pejorative term used by Parliamentarians during the civil to describe Royalists. ${ }^{116}$ CSPD , 8: 98.

${ }^{117}$ CSPD, 8:224-225.
} 
dissent, ${ }^{118}$ and there were examples of preachers inciting the people to rebellion. Though the measure was strongly worded and might seem rather harsh, it was only applied to those who actively preached sedition, by either criticizing the Protector, advocating his overthrow, or preaching the return of the king. The term, "disturbers" also referred to Quakers, famous for peace-breaking displays such as verbally abusing ministers in their pulpits, and radical Protestants known—with varying degrees of accuracy—as Anabaptists, Levelers and Fifth-monarchists: sects which were considered dangerous and were suspected to have planned to ally themselves with the Cavaliers of Penruddock's rising. ${ }^{119}$ Generally, the ordinance was not designed to install Cromwellian Congregationalist clones in all the ministerial livings but rather to encourage the settling and maintenance of moderate, loyal Protestants who left politics alone.

July $6^{\text {th }}$ saw another proclamation ordering all those who had been "party of the late King" to depart London and Westminster. It also ordered those who had "born arms against the State to depart from within the lines of communication" lest they be "proceeded against as disturbers of the peace and contemners of authority." ${ }^{, 20}$ Sheriffs, JPs, aldermen, constables, etc. in the London area and the Southeast, including Essex, were to "have strict wards and watches kept, make frequent searches of such persons, and certify to the Council, that offenders may be proceeded against." ${ }^{121}$ This order served not only to reduce the possibility of assassinations and coups where members of the government lived and worked, but it allowed the state to keep better watch on Royalists

${ }^{118}$ CSPD, 8:145.

${ }^{119}$ Worden, ECW, 108-9, 126; Woolrych, Britain in Revolution, 602.

${ }^{120}$ CSPD, 8:232-3.

${ }^{121}$ CSPD, 8:232-3 
and prevent the development of secret plots. Unable to meet, such persons would have to communicate by courier or by post. Since the roads — which were the main lines of communication-were watched and the post was monitored by Secretary Thurloe's men, dispersal to their homes would mean that any plots were more likely to be discovered. ${ }^{122}$ Whether intended at the time, it also set them up nicely to be subjected to the oath of abjuration and then to either sequestration or taxation under subsequent ordinances. These were individual measures that reflected a consistent preoccupation with the threat of domestic rebellion. But sometime in the summer the council began work on a plan which would increase security against potential rebellion: new militias.

\section{The conception of the "poor little invention"}

Council minutes are lacking from the Interregnum, so it is difficult to know the exact thinking process or sequence behind the development of the government's solution to its security problem in the localities. But considering the willingness of "wellaffected" horsemen to come to the defense of the nation in March and their low cost, the ideas of raising new horse militias probably came easily to the security-conscious Council of State. In such fiscally challenging times, cost was probably the greatest obstacle to establishing a new military force. Such troops were cheaper than full-timers, but they still wanted to be paid. ${ }^{123}$ So to fund the new militias a plan was hatched: tax the enemies of the state. Raising revenue from the sequestration of Royalists, those who had fought against Parliament during and after the Civil Wars, was certainly nothing new, and taking the estates of traitors was standard throughout the early-modern period. But to

\footnotetext{
${ }^{122}$ Philip Aubrey, Mr. Secretary Thurloe: Cromwell's Secretary of State, 1652-1660 (London: Athlone Press, 1990), 94-128.

${ }^{123}$ Gaunt, 100-104.
} 
maintain a permanent additional force the government needed a new fiscal expedient. In short, the government developed a plan that would kill two birds with one stone: insecurity and the cost of defeating it.

By the beginning of August the council had settled on an idea of who would command the newly-raised militia forces. Rather than depending on civilian militia commanders, sheriffs, or other local officers of dubious loyalty or experience, it was decided to appoint army officers to do the work. On August $9^{\text {th }}$, the Council divided the country into ten districts, and an army officer was assigned to supervise each. ${ }^{124}$ In the council orders, those to be appointed were referred to by their military rank at the time and not as major-generals, the rank to which they would eventually be elevated when they took their posts in the localities, an indication that the council was probably still working out the scope of their authority over time. ${ }^{125}$ Eventually the Council would further split one of the districts so that they totaled twelve, and each regional commander would be commissioned as a major-general. The work of some of the major-generals would be assigned to a deputy, such as in East Anglia, where Hezekiah Haynes would command in the absence of Cromwell's son-in-law Charles Fleetwood. ${ }^{126}$ According to the records, at this point the officers were intended only to "command the militias." Traditionally, militias consisted of those who were partially trained, lived in the counties where they served, mustered occasionally, and could be raised to defend the country

\footnotetext{
${ }^{124}$ CSPD, 8:275; Durston, 30-31.

${ }^{125}$ CSPD, 8:275. The fact that it was not settled in one fell swoop indicates that the program began with an initial concept which was altered in response to other contemporaneous issues and developing priorities. ${ }^{126}$ CSPD, 8:387.
} 
when invasion threatened. ${ }^{127}$ The reason army officers were selected for the task was that they were best suited to command military forces; it was not because the Council planned to instill military-style order in the localities.

Later that month, the council reviewed the instructions of Cromwell to the militia commanders. Their remit had expanded, but it was still focused on security. The directive in the state papers began "We and our Council, to preserve the nation from the designs of restless and unwearied enemies, have ordered the enlisting of troops of horse in the several counties, and appoint you our Major-generals." In addition to raising the militias, the instructions listed a variety of tasks, primarily concerning order: "Suppress tumults and rebellion," "Papists who assisted the late King have their arms secured," "make the highways safe," "work with others to promote the "quiet of the country'," "keep a strict eye on the disaffected," and "inquire into idlers." It also mentioned that the men should "promote godliness...acting with justices of the peace and ministers against drunkenness, blaspheming, etc." ${ }^{128}$ But the high-ranking army officers were also, and no less importantly, given the task of making sure that the poor laws were being enforced. Also included was the rejoinder to help "those appointed to levy a tax for the maintenance of the said forces, on the estates of delinquents who assisted the lake King, or Charles Stuart, his son." However, the first and most important clause instructed the raising of militias to deal with potential outbreaks of rebelliousness.

\footnotetext{
${ }^{127}$ Fletcher, Reform, 282-284.

${ }^{128}$ CSPD, 8:296-297. The promotion of Godliness was a rather vague term, the definition of which depended on the religious inclinations of whoever wished its promotion. At this time among the godly it usually entailed various prohibitions on unseemly social behavior such as swearing and being drunk in public.
} 
The instructions, slightly amended and then approved by Cromwell and the council a few days later, seem hardly a license to wreak terror or impose iron rule on the countryside. Conversely, even the instruction to put a stop to cock fighting, horse races, and other unlawful assemblies is explained "as rebellion is usually hatched on such occasions." ${ }^{29}$ The only clause which might be read as possibly harsh or threatening to locals was one that gave the officers the power to dismiss justices who in the suppression of minor moral offences were "remiss." However, this power had long been exercised by administrators under Tudor and Stuart monarchs. ${ }^{130}$ Central government had always had the power to choose who sat on the benches and had often removed persons who were thought to have been anathematic to its aims. So the power to remove justices was not unusual; only the social rank of the person doing the removing had changed. It certainly did not entail the wholesale purging of the benches or corporations; it merely gave the major-generals the authority to require duly appointed or elected officials to act on the many previous statutes and ordinances designed to discourage such behavior. Besides the provisions for the militia and taxation in the instructions, much of the officers' other work was hardly innovative and seems to have consisted of looking into previously mandated matters.

\section{Commanders-in-Chief}

\footnotetext{
${ }^{129}$ CSPD, 8:296-297. The editor of the volume notes that on the document original, the final clause, that authorizing assistance to those taxing the Royalists, was omitted and replaced by another. The replacement, added two days later when the instructions were reviewed and approved, would have likely been very similar, considering that the major-generals did, in fact, immediately concern themselves with taxing royalists when they met their commissioners in the counties.

${ }^{130}$ Fletcher, Reform, 12.
} 
It bears repeating that it was against the backdrop of financial insolvency, military defeat, rebellion, and further threats of disorder that the Council prepared to install the major-generals in their commands; they drew up the instructions in the milieu of external and internal threats. The commission of the major-generals ${ }^{131}$ would read much like the instructions listed above with a somewhat more aggressive and condemnatory tone. But compared to the previously mentioned instructions, it placed sole emphasis on the overriding purpose of their office: security against domestic risings and foreign foes.

Commission by the Protector to the Major-Generals. The old malignant and Popish enemies, after an Act of Oblivion, and many other favors, have designed a new and bloody war, and by correspondence with other discontented parties, resolved on a general rebellion, and executed it in many places; but it was suppressed by God's mercy, or a bloody war might have followed, as they had engaged the aid of foreigners, promising them on success some of our sea towns. Yet they still are stirring up new troubles, and engaging foreign princes to invade us, and will leave nothing unattempted to embroil us in war.

We have therefore raised a well-affected militia of horse, and as they need a commander to discipline and conduct them, we appoint you Major-General and Commander-in-chief in counties, —_ with full power to keep the said militia in good discipline, conduct them to fight against all enemies, traitors, etc., and resist, repress, and slay them. We give you power, in case of invasion or rebellion to raise the inhabitants of the said counties, and to exercise, arm, muster, and conduct them to the places where we shall direct you, in case of rebellion.

As there may be causes why you cannot always exercise your office in person, we give you power to appoint a deputy with the same authority. All justices of the peace and other civil officers to assist you. ${ }^{132}$

The commission gives no mention at all of ancillary or "moral" aims. It focused entirely on being prepared in case the enemy aimed to "embroil us in war." It gave the officers the power to raise troops to fight the enemy "in case of rebellion," but it

\footnotetext{
131 "Commission" here refers to the document mentioned immediately below which actually gave the major-generals their authority.

${ }^{132}$ CSPD, 8:344.
} 
was clearly not designed to create a force of crusaders or moral reformers sent to sweep aside the apparatus of local justice. This is not to say that the government had turned away from all religious motivations in its policies and actions, including this one. But particularly in the case of the localities such concerns were not the moderately Puritan government's only—or even primary—aim. The focus is on defending against armed attack. It is also difficult to find much in the document that smacks of tyranny or "arbitrary government" unless, of course, read by a Royalist whom the "Commander[s]in-chief" might "resist, repress, and slay" in any subsequent rising. The government had been caught unprepared once; it intended that such a surprise would not happen again.

The major-generals were intended to command a new force raised for national defense. But for some of the officers, working to defend the localities was hardly new, and some, like Major Hezekiah Haynes, were already engaged in such work. Haynes, whose brother, also an army major-general, had been killed in the expedition to the West Indies, ${ }^{133}$ had been operating as a regimental commander in East Anglia and had for some years been the acting commander of Fleetwood's horse regiment. ${ }^{134}$ Previously in the Interregnum, he had served in a number of administrative posts in central government. ${ }^{135}$ During Penruddock's rising, Haynes had been tasked with securing the important town of Colchester, which had been the site of a major rebellion in the Second Civil War, and supervising those who rose to the government's defense. In the months that followed the

${ }^{133}$ CSPD, 8:369. After Major-general Robert Haynes' death, his wife was assigned lands worth $£ 150$ per year by the Council.

${ }^{134}$ Godfrey Davies and C. H. Firth, The Regimental History of Cromwell's Army (Oxford: Clarendon Press, 1940), 2:xiii, 96-98; "Haynes, Hezekiah (d. 1693)," Christopher Durston in Oxford Dictionary of National Biography, ed. H. C. G. Matthew and Brian Harrison (Oxford: OUP, 2004); online edn., ed. Lawrence Goldman, January 2008.

${ }^{135}$ W. L. F Nuttall, "Hezekiah Haynes: Oliver Cromwell's Major-General for the Eastern Counties," Transactions of the Essex Archaeological Society, vol.1, pt.3 (1964): 197-198. 
rising of 1655 he would be active in preventing any signs of fomenting rebellion. From March of 1655, he was the primary link between the government and East Anglia, keeping an eye on royalist supporters of Charles Stuart, and dealing with prisoners who had rebelled or threatened rebellion. ${ }^{136}$

When several dozen men of the East Anglian counties were released the October after the rising, Haynes was tasked with placing them under a surety requiring them not to "plot or conspire against the Protector or present Government; they shall reveal any plots...to his Highness and Council, or to the justices of the peace; and that they shall appear on summons for one year." 137 There was no outcry against him as a tyrant in exercising that authority, and it seems unlikely that the new commissions which directed him to resist rebellion would have incited him to adopt an overbearing attitude toward unthreatening locals once he began to exercise his new authority. When the majorgenerals assumed their commissions they would continue to obtain sureties from those who had demonstrated their disaffection toward the government. They would also be tasked with one additional very unpopular responsibility: collecting the decimation tax.

The order detailing the decimation tax and further instructions for "securing the peace of the Commonwealth" was issued on September $21^{\text {st }}$. Even before giving the details of the decimation tax, the order directs the sequestration of any who had “engaged...in any rebellion" since late 1653 . Those who had risen against the government and all "who adhere to the late King, or Charles Stuart" were to be

\footnotetext{
${ }^{136}$ TSP, 3:284-5.

${ }^{137}$ CSPD, 8:367-369.
} 
“imprisoned or deported." 138 This particular instruction might seem rather ominous and thus tyrannical or "arbitrary," but it was aimed specifically at those who had clearly threatened the government, and it levied those fairly severe penalties for direct attempts to topple the government. Also, sequestration-and often execution-were had traditionally been the penalties suffered by those who rose in arms against the state. However, such penalties were very infrequently applied to all but the most recalcitrant opponents of the government. Also, when assessing whether directive is unduly harsh it should be considered that the actions were taken in response to a rebellion, and the Council was in the process of ensuring that those who continued to present a significant threat would be marginalized. Again, it was not "arbitrariness" the government was after but security.

Next, the council order gives details of the new tax. It was to be applied to all "who have been sequestered for delinquency, or have fought against Parliament." They would pay ten percent of their landed income if that income was $£ 100$ or more. Or if they had insufficient income to meet the income tax threshold but possessed $£ 1,500$ worth of landed property, they would pay $£ 10$ per year per $£ 1,500$ of that property’s value. The tax would be divided into two yearly installments, the first to be paid on December $21^{\text {st }}, 1655 .{ }^{139}$ This was the decimation tax, a ten percent tax on the income of the Royalist party. In the ensuing decades and centuries, the word decimation-rarely

\footnotetext{
${ }^{138}$ CSPD, 8:346.

${ }^{139}$ CSPD, 8:346-7.
} 
used in English before that time-became infamous for its association with Cromwell and the major-generals. ${ }^{140}$

The order, unlike the major-generals' commission, did also address a variety of matters other than just the militia and taxation, some of which might seem to have no relationship to the "security of the Commonwealth." One directed that those who "live loosely and cannot give account of themselves" were also to be "sent to foreign parts.",141 This instruction may have been aimed at the fear of popery-particularly Catholic priests-who might be wandering the countryside to stir up rebellion and coordinate plots against the government, though prostitutes (who lived loosely) were also rumored to have been deported. ${ }^{142}$ Another directed that "none of the party"-meaning Royalists—were to be allowed to have religious personnel in their houses on pain of a doubled assessment. Superficially, this might seem a measure designed to oppress those with religious opinions different from those of Cromwell and the army. But rather it was intended to prevent the dangerously disloyal from coming together and fomenting rebellion during religious services in private homes. Even before the Civil Wars there were endless and persistent rumors of Jesuits, who were thought a security threat in the vein of Guy Fawkes, being harbored in people's homes, holding secret services and proselytizing, and turning the people against the nation and the Protestant religion. ${ }^{143}$ Also, there was a persistent fear that Royalists would harbor and support "chaplains, schoolmasters, ejected

\footnotetext{
${ }^{140}$ CSPD, 8:346-7; OED Online, s.v. "decimation, n." (Oxford University Press, March 2012).

${ }^{141}$ CSPD, 8:346-7

142 Josselin, 363.

${ }^{143}$ Guy Fawkes was a Catholic who attempted to blow up the Houses of Parliament in 1604. Kishlansky, 65-6.
} 
ministers, or fellows of colleges" who would preach against the government. ${ }^{144}$ Such preaching was generally felt to be dangerous and capable of turning well-affected or neutral people against the state. Ministers and the like who engaged in such activities were threatened with a few months imprisonment "unless their hearts are changed, and they obtain the approval of the Commissioners for Public Preachers."

Though these measures spoke of religion, they were not aimed at instituting doctrinal conformity of forcing a particular confessional view on the people. The instructions were inserted with the fear of either Catholic plotting-like the earlier order on April $24^{\text {th }}$-or ministers who might spread sedition in mind. ${ }^{145}$ The behavior of Nehemiah Rogers justified the government's concerns. The former minister of Purleigh, in Essex, was found to have preached a sermon in which he demonstrated that the government had been in violation of all Ten Commandments, saying they were "thieves and robbers, which take away violently that which is not their right" and that Whitehall "stinks of the brimstone of Sodom."146 Naturally, the Council was concerned that preaching of that sort would incline religious people to act against the "ungodly" godly government. The same order also included other security measures. Cavaliers were prohibited from possessing arms or returning to the country if previously banished. The order also provided that "a competent number of Commissioners" would be appointed in

\footnotetext{
${ }^{144}$ CSPD, 8: 346-7.

${ }^{145}$ Colin Davis, "Cromwell's Religion," in Smith, Cromwell and the Interregnum, 139-140, 147-9. Oliver Cromwell was a well-known early advocate of limited religious tolerance.

${ }^{146}$ TSP, 3:484-485.
} 
each locality. ${ }^{147}$ These were the previously-mentioned commissioners who would assist the major-generals with their work in the counties.

The order was actually part of a laundry list of measures enacted throughout the year designed deal with what the Council saw as threats to the security of the government and nation. Simply because religion is mentioned does not make it a document or program with a primarily religious purpose. All government proclamations and orders during the period were laced with religious language and couched in terms of religious motivations. Thus, the increase in security was certainly not designed to promote right religion; instead, wrong religion, which meant religion practiced and promoted by the enemies of the state, was to be suppressed because of its role in promoting rebellion. Having lived and fought through two Civil Wars motivated in part by confessional differences, the Council was well aware of the danger some religious practices could present.

This directive and provisions - as in the several others in the same vein in the preceding months - consisted entirely of measures which would contribute to the elimination of the sources of disorder, be they social, religious, or political. The order outlining the details of the tax was soon followed by another requiring "all who have been of the late King or his son's party" to depart from London and return to the counties to which they belonged. ${ }^{148}$ This order restated an item of July $6^{\text {th }}$ which had contained almost identical wording. It was aimed at the removal of dangerous persons from the environs of the government and Protector, whose safety was in doubt from fear of threats,

${ }^{147}$ CSPD, 8:346-7.

${ }^{148}$ CSPD, 8:395. 
and at facilitating the monitoring of those persons by the well-affected in places where they were known. It was also likely to have been designed to facilitate their submission to the decimation tax.

\section{A Declaration and justification}

On October $31^{\text {st }}$ the government published the announcement which presented its official position on the major-generals' commissions and the decimation tax, the Declaration of the Highness in Council, showing the reasons of their proceedings for securing the peace of the Commonwealth, on occasion of the late insurrection. Focused on justifying the program to the public, word of which had gotten out months before, ${ }^{149}$ the majority of the text outlines the threat presented by Penruddock's rising of March and details the plot to undermine the government, as already discussed in this study. With its publication, the major-generals would begin to work at their new tasks in the shires.

The Declaration includes a letter from Charles Stuart to the rebels inciting all loyal men to support him in an attempt to regain his throne. ${ }^{150}$ It seems rather curious that during a period when further risings were feared, Cromwell's government would publish a letter from the heir of the abolished Stuart throne-one which would seem to give the erstwhile king a national voice to encourage the nation to aid his cause in usurping the usurper. But the letter, accompanied as it was by the government's interpretation of it, makes absolutely plain not only the continued threat of rebellion by showing Charles' abiding and unwavering support for anti-government rebellion,

\footnotetext{
149 TSP, 4:116.

${ }^{150}$ A Declaration of his Highness...for Securing the Peace of the Commonwealth (London, 1655), 25-6. Wing C7082
} 
whenever and wherever it should occur. More importantly, it also allowed the Council to impute all Royalists in the "late insurrection."

That if they who wish one and the same thing knew each others minde, the work would be done without any difficulty; and if there were any handsome Appearance in any one place, the rest would not sit still; and I am persuaded that I should then find supplies from those, who are yet afraid to offer them. ${ }^{151}$

For the Council—and they hoped in the eyes of the nation as well—the letter proved beyond any doubt that Charles believed that his supporters everywhere would rise if the rebellion were sufficiently great in any one part of the country. Charles also expected them to rise not on the grounds of a specific call or a specific issue but simply because they were Royalists and were thus ready to do so at any time—and would be ready to do so at any time in the future. Also, Charles wrote that Royalists were all of "each others minde," whether they had actually rebelled or not. For the Council of State and Lord Protector, Charles' belief points to the collective guilt on the part of all of the "king's party" for the March plot discussed earlier in this chapter and the conspiracy behind it, known as the Sealed Knot. ${ }^{152}$ Because Royalists' guilt was collective, and because of the threat that supporters of the king continued to present, taxing them and enforcing additional security measures to prevent further risings were all justified. Charles was still alive and quietly waiting to topple the government and English Royalists were no different. They had been and were still rebels, and they wholly deserved to be watched, taxed, and treated as a danger to the state.

\footnotetext{
${ }^{151}$ Declaration, 25-6.

${ }^{152}$ Declaration, 25-6.
} 
The Declaration further detailed the money raised and spent to further the March rebellion, and it showed the very real threat by revealing the numbers of troops that had been raised across the channel which plotters had expected would have supported the failed insurrection. It also mentions that it was God's intention that the forces of the "late King and his party" be "wholly vanquished," which should have been apparent to all. During those times of providentialist belief, defeat signaled God's displeasure, and both Charles I and his son, Charles Stuart had been repeatedly defeated by Cromwell. Though members of that "party" had been given the opportunity to accept God's divine judgment regarding the nation, and had been graced with the pardon of 1652, they still stubbornly persisted in their course of rebellion. After "four years contrivance" their "cruel and bloody design" of 1655 in which they "sent agents to procure men and money from foreign states" had been defeated. ${ }^{153}$ Having continued to support rebellion with their affections toward the divinely disestablished king, it was only right that "the party" which was "so unanimous and resolved" be required to pay. "The Act of Oblivion was intended to be answered with obedience; but this failing, it is no longer obligatory" that the government should adhere to it in the case of those who supported the king. The Declaration further addresses the issue.

It may seem great severity to tax the whole party, when few have been convicted or detected, in which case their whole estates had been confiscated, but we appeal to all indifferent men whether the party was not generally involved in this business.

No one can suppose that the pretended King would have proposed to land...and men would actually have risen, unless they relied on more persons than those who were visible. The great sums raised could not

${ }^{153}$ Declaration, 31-32. 
come out of a few hands. The party kept together, spoke against the wellaffected, and some boasted of a sudden change. ${ }^{154}$

These were the grounds for the decimation tax. Royalists were to be taxed not on evidence but rather on the presumption of guilt, or literally guilt by (past) association, though there was no proof in the case of most individuals. Cromwell ultimately held the Cavalier party responsible for what they almost certainly would have done. In this assumption were the seeds of the reaction to the major-generals and the resentment toward them. After all, what would seem more unfair than taxing-or rather fining perpetually — men based on an opinion they might have held? For its critics, the Declaration flew in the face of the authority of Parliament as stated in the Act of Oblivion, which had stated that all persons

shall be and are by the Authority of this present Parliament, Acquitted, Pardoned, Released and Discharged (as against the Parliament, the Keepers of the Liberty of England by Authority of Parliament, or any or either of them) of all manner of Treasons, Felonies, Offences, Contempts, Trespasses, Entries, Wrongs, Deceits, Misdemeanors, Forfeitures, Sequestrations, Penalties and Sums of Money, Pains of Death, Pains Corporal and Pecuniary, and generally of all other things, Causes, Quarrels, Suits, Judgements and Executions, had, made, committed, suffered or done before the third day of September, in the year One thousand six hundred fifty one, in this present Act hereafter not excepted nor foreprized. ${ }^{155}$

As with all acts of oblivion, there were exceptions to what was forgiven. But having fought for the king in the past was clearly not one of them. Royalists who remained at peace had been reprieved by act of Parliament; the Declaration contradicted that act. So it seemed that Cromwell was not only reneging on a promise he had made by supporting the Act of Oblivion in 1652, but he was also defying the people's representatives: the

${ }^{154}$ CSPD, 8:410-411.

${ }^{155} A$ and $O, 565-577$. 
Protector and Council were holding themselves above Parliament, ancient rights and liberties, and the very law itself.

In an interesting turn, the Declaration suggests that those who had been Royalists, but who truly came to support the "cause" of the Commonwealth, should feel glad to pay to support the additional measures of security ${ }^{156}$ by asserting, "But supposing some are innocent, yet as they avow, and love and glory in the cause, it is but just that they should share in the charge of securing the State against the dangers of which they are the authors."157 It seems unlikely that this clever turn would have convinced many who were being required to pay the additional, punitive tax that it was just; but, perhaps supporters of the government who had their doubts about the justice of the tax (and were not themselves subject to the tax), might have been reassured by this line of reasoning. In fact, the declaration proclaims that "we publish these things chiefly that the well affected may be encouraged," suggesting that the audience for these words was not as much the Royalists as the moderates and the godly whom the government hoped to convince with this line of reasoning. ${ }^{158}$

In general, the Council and its allies seem to have been convinced of both the moral rightness and the usefulness of the tax, particularly as vengeance for the trouble and threat that Royalists and their sympathizers continued to present to the Commonwealth. Commenting on the trials which followed the rising of 1655, Ralph Harner, a local supporter of the government, wrote to Thurloe that he was glad to see

\footnotetext{
${ }^{156}$ CSPD, 8:411.

${ }^{157}$ CSPD, 8:411; a fairly obvious contradiction that those who "love and glory" the state would not threaten it.

${ }^{158} \operatorname{CSPD}, 8: 411$.
} 
swift justice meted out to the rebels, and that the "souls that thirsted for blood" would "drink of that cup they intended for others." 159 The same sentiment is apparent in the Declaration regarding the tax: Royalists should be made to suffer and to bear the cost of their continued disloyalty. Also, defensive preparations were again mentioned as the reason for and reasonableness of the tax, which was for "a standing Militia of horse in all counties, under such pay as may encourage them, and yet not be burdensome." 160 Despite the cost of additional defense being laid at the doorstep of the Royalist "party," there were provisions in the declaration to ensure that it did not fall upon those who had truly abandoned their allegiance to the king. The Declaration contained a stipulation for those who were demonstrably no longer of the party that had fought against Parliament in the "late wars."

If any wish to leave this confederacy, and can truly say that he has changed his interests, and can show, by good works before the late insurrection, a disclaimer of his former course, and means in future to live quietly, he shall be dealt with according to his integrity; or if any forsake their former interest, and give real demonstrations thereof, we shall more esteem their reformation than desire their harm. ${ }^{161}$

These stipulations do show a concern by the council and Protector for fairness. They earnestly desired that the country be safe and blamed the Royalists, often rightly it must be said, for the threat to government and order. ${ }^{162}$

Though one of the reasons for the tax was lex talionis, the main one was security. One means of preventing rebellion was thought to be demonstrating the consequences

\footnotetext{
${ }^{159}$ TSP, 3:268.

${ }^{160}$ CSPD, 8:410.

${ }^{161}$ CSPD, 8411.

${ }^{162}$ Rightly in the sense that it was generally the Royalists who participated in risings, though they were hardly alone: there were plenty of other factions and sects who plotted and schemed against the Commonwealth or Protectorate.
} 
opposition to the government. The Declaration conceded as much regarding the tax, appealing to precedents of crown practice far older than the Act of Oblivion, stating, "This is agreeable to many precedents, which were intended to terrify men from such attempts in the future." ${ }^{\prime 63}$ Interestingly, the Declaration also expressed regret at having to resort to such tactics. "It is contrary to our former principles of trying to oblige them by kindness, but we are constrained thereto."

Ultimately the tax put the financial burden for defense on the guilty, or those blamed for "the late troubles." 164 By taxing and discouraging those responsible for the need for extra troops, the government aimed to put the possibility of rebellion in the past. For a time they had tried to heal and settle the nation with lax security, but the plots of Charles Stuart and other Royalists had necessitated more security. It was primarily with security in mind that major-generals took to the countryside to assume their posts.

${ }^{163}$ CSPD: 8, 411.

${ }^{164}$ Declaration, 5. 


\section{Chapter Two}

\section{Into the Counties: Soldiers and Decimators}

His highness saw a necessity of raising more force, and in every county, who might be ready upon all occasions, unless he would give up his cause to the enemy, and leave us all and the whole kingdom exposed to their rage and malice. ${ }^{165}$

Secretary of State John Thurloe's memorandums, October 1655.

The major-generals went to their counties, orders in hand, after the Declaration of October 31, 1655. Some, like Hezekiah Haynes who, as noted in the previous chapter, was from an Essex minor gentry family and had been commanding Fleetwood's East Anglia regiment, went to familiar places. He was well enough established to have been a frequent dinner guest at the home of diarist, political moderate, and non-conforming pastor Ralph Josselin. ${ }^{166}$ Others were either not from the areas they supervised or not well enough known to have been familiar with the local political and social landscape.

\footnotetext{
165 Secretary of State John Thurloe's memorandums, October 1655, as quoted in TSP, 4:133.

166 Josselin, 23-125.

166 Josselin, 23-125.
} 
Nevertheless, by November of 1655 it seems that most were in their counties and were absorbed in the business of their commissions. Each county also had commissioners who were assigned to it, and the major-generals were met by some of those men when they arrived. Compared to what is known about the major-generals, the commissioners are relatively anonymous. As usual in such times and circumstances, they were of varying backgrounds. Some had been pre-selected by the Council as mentioned in chapter one, but the commissioner lists were printed with blanks for those who might be added later. ${ }^{167}$ Christopher Durston observed that these men were generally of low-to-middle birth, ${ }^{168}$ and Major-general William Goffe noted, "I doe see the stresse of this busines must lie upon the midle sort of men." ${ }^{169}$ Nationwide it seems the commissioners were often of lower status than those who traditionally supervised the counties, the JPs. Also, a fair number had military rank. But regional variations were significant, as we shall see in the following chapter.

Though they were men of military experience who had fought in major battles, the major-generals often felt daunted by their tasks. Major-general Charles Worsley wrote "The sense of the work, and my unworthiness and insufficiencie as to the right management of it, is my only present discouragement." ${ }^{, 170}$ The major-generals frequently encountered like misgivings in those appointed to assist them as well. Unlike JPs, who would have been familiar with duties such as taxation, justice, and administration, the commissioners were less experienced in such matters. Not only were their duties

\footnotetext{
${ }^{167}$ Durston, 59-60.

168 Durston, 59-71.

${ }^{169}$ TSP, 4:161.

${ }^{170}$ TSP, 4:149.
} 
unfamiliar and in some cases_-in particular, the decimation tax-completely new, but they frequently anticipated resistance. ${ }^{171}$ Despite these issues, there were many positive signs. Hezekiah Haynes reported that the "Declaration...hath a good acceptance" and that the commissioners "seem exceeding real and forward in the putting the [instructions] in execution." ${ }^{172}$ Colonel Robert Jermy, working in Norfolk under Haynes, expressed satisfaction in being able to "promote so good and just a work as the making of a discrimination betwixt the innocent and the guilty.",173

\section{The "quickest hedge"}

Within their districts, the major-generals followed a sort of assize-like circuit. They would travel to a town, meet the commissioners, find a place to set up an office, and then begin work on taxation and the formation of the new horse militias. In the case of taxation, there was much said; regarding the militias, but little. The lack of correspondence regarding the militias was likely to do with the ease of forming them. There was nothing new about militias, for they had long been a regular part of country life, and the major-generals were all experienced army commanders. Members of the new militia worked for pay and had formed up spontaneously during the 1655 rising, so recruitment would not have been especially difficult. Goffe wrote to Thurloe from Lewi[e]s in November. "As soon as I reached this town I dispatched officers of the militia and I hoped on Tuesday next to have all the commissioned officers of the three troopes together, if they bee in the country." ${ }^{174}$ Two days later he reported that he had

\footnotetext{
${ }^{171}$ TSP, 4:179.

${ }^{172}$ TSP, 4:170-1.

${ }^{173}$ TSP, 4:171.

${ }^{174}$ TSP, 4:151.
} 
met the men, they had been wholly positive regarding the plans, and that they openly received "the council I was [told] to give them in reference to their carriage to all men, but especially toward one another and all saints." It is interesting to note that Goffe was aware of the potential effect that raising the militias would have had on the populace, and he was quick to ensure they treated godly supporters and all others with due respect. He directed the militia officers to carry the message to the men, to be observant regarding their condition, and report back so that "I may have a better knowledge of these blades I am to deale with."175 In any case, there seem to have been few troubles raising the necessary troops. Worsley in Lancashire had a similar experience. Regarding the militia he wrote, "I have been with most of the officers, what command the countie troops...and truly I find in them a spirret extraordinarily bent to the worke." ${ }^{176}$ If there was a difficulty, it was with the quality of the men and their equipment. Major-general William Boteler reported a certain degree of exasperation because some of the men who turned out were "unfitt, and many had not horses of theire owne; which was altogether insufferable." To remedy the situation he was "reforming our militia, putting out, and putting in.",177

Goffe reported that the militia do "readily acknowledge themselves...as the new quickestt hedge, that will for a while need an old hedge about it." It is difficult to say whether by the "old hedge" Goffe means the army or the previous militia, though considering Goffe's hopes that the Protector "will be so good a husband, as not to take away the old one, till the new be growne very substantiall," the former seems more

\footnotetext{
${ }^{175}$ TSP, 4:151.

${ }^{176}$ TSP, 4:149.

${ }^{177}$ TSP, 4:156.
} 
likely. ${ }^{178}$ His comment reveals possible long-term intentions of the Council of State regarding the new horse militias: completely replacing regular troops with the new militias. This might have been the reason that officers of such high rank were employed in organizing a force seemingly intended for little beyond occasional emergency defense. Had the horse militias replaced full-time soldiers completely, they might have been the most important—or perhaps only remaining—soldiers on the island. Loyal, local, costeffective, and well-commanded: the horse militias seemed very much like the "russetcoated" sort on which Cromwell had relied his entire career and on which he hoped to rely in the future to secure the countryside and the state. Whatever the long-term plans for the troops, in regard to raising them the major-generals reported success-to the extent there were any reports at all. In this case, silence was golden.

\section{Echoes of ancient Rome}

In the matter of gold, however, there was less silence and more difficulty. Despite the officers' trepidation, the beginnings were auspicious. After arriving in his district, William Boteler wrote, "To-morrow I have summoned the cavaliers of this county to be at Northampton, where I shall take security of them as directed by the instructions." ${ }^{179}$ Generally, the major-generals would summon Royalists with sufficient income by writ, and then a discussion would ensue regarding their income and the value of their lands. Usually the commissioners and their bosses were surprised at the limited amount of open resistance from Royalists they encountered. Most of those to be

\footnotetext{
${ }^{178}$ TSP, 4:160-161.

${ }^{179}$ TSP, 4:156.
} 
decimated took their oath, agreed on a sum and then paid their half-yearly increment. ${ }^{180}$ Edward Whalley reported that "those cavaleers, that have bin before us" showed "a readyness to submit." ${ }^{181}$ Haynes reported after they commenced the work that, because of the encouragement his commissioners gave to one another, and their enthusiasm for the work, "the delinquent" had "not one word to say, why ought should be remitted him." 182 Thurloe commented to Henry Cromwell in Ireland that there had been "a vary reade complyance from the gentlemen of the countye" and that the Cavaliers did "quietly submit to this new way of taxinge them." Based on the progress of the tax, Thurloe was optimistic about the entire initiative, saying "through the blessing of God there is like to be a very good use of the raysinge of the new militia.... and the nation is likely to be kept thereby in peace from those continued dangers." 183 On hearing such positive news, Henry Cromwell expressed his interest in creating similar militias in Ireland to defend against Spain in case of invasion. ${ }^{184} \mathrm{He}$ did not see the major-generals initiative as a design to reform an ungodly nation (which for Protestants, Ireland certainly was). Rather, he saw it as a means to defend against a potential invasion from the pro-Catholic enemy via England's potentially traitorous back door. Like the Council of State, Henry Cromwell thus also saw the program as a "hedge" against invasion or rebellion.

To make the summons the major-generals needed to know who the members of the Royalist "party" were. Often the major-generals had little idea whom to tax. Majorgeneral Edward Whalley wrote from Newark, he "upon debate apprehend it very

\footnotetext{
${ }^{180}$ TSP, 4:189, 215-216.

${ }^{181}$ TSP, 4:162.

${ }^{182}$ TSP, 4:216.

${ }^{183}$ TSP, 4:190-1.

${ }^{184}$ TSP, 4:198.
} 
necessary in order to our more effectual proceedings therein, that we have a list of all those in this county...with the particulars of their compositions." 185 Perhaps the officers had expected more help from the local commissioners and JPs in identifying those aligned against the state because they were often at a loss for whom to tax. In any case, they often found it necessary to write to Thurloe asking for information. Many had questions for Secretary Thurloe regarding aspects of the tax, such as whether the values were to be calculated with or without considering any financial obligations on the land. ${ }^{186}$ Eventually they received word that no deductions of the sort were to be counted against value. The major-generals' letters to Thurloe are also filled with respectful requests for "more of the printed materials." ${ }^{187}$ Printed materials, manuscripts, and news often trickled into the localities after being produced in London, the only place in England where government printers were licensed to operate, ${ }^{188}$ so it is hardly surprising that without a deliberate public information campaign the localities would have been underinformed. But the Council's failure in not previously sorting out the details of whom to tax and how to administer the tax indicates a lack of forethought on its part. Whitehall may have spent months conceiving the major-generals initiative, but it seems to have spent less time than necessary in anticipating problems and the political consequences of the reaction to the tax.

\footnotetext{
${ }^{185}$ TSP, 4:156.

${ }^{186}$ TSP, 4:179.

${ }^{187}$ TSP, 4:211.

188 Tessa Watt, Cheap Print and Popular Piety, 1550-1640 (Cambridge: Cambridge University Press, 1991), 5-7.
} 
Though the major-generals initially reported success, eventually resistance seems to have increased. Goffe thought that those taxed took it "very much to hart,", 189 particularly considering that some Royalists were asked to make a double payment: both the decimation tax and a surety for good behavior. Goffe had sympathy for their plight, and asked that the tax be levied first and then the sureties which Royalists were often required to pay be taken later because of the burden of paying both at once. ${ }^{190}$ Some Royalists claimed to have known nothing of the plots or the tax, ${ }^{191}$ and these protestations of ignorance prompted the major-generals' calls for more printed materials. ${ }^{192}$ For Royalists it was probably easier to protest ignorance than to proffer outright defiance, and those with experience knew that temporizing was often the easiest and most effective form of resistance. In fact, Goffe thought that the Royalists "pretend too much innocency." 193 The major-generals were usually able to overcome this resistance and make Royalists pay up. At times the officers resorted to strong-arm tactics, as when they quartered troops on the Duke of Northumberland who had flatly refused to pay. ${ }^{194}$ But the major-generals' and commissioners' power was limited by the right to appeal to the Protector, who was all too willing to grant exceptions to those who could offer favor or justify their case. ${ }^{195}$

Over time, the major-generals' initial enthusiasm seems to have eventually given way to exhaustion. Royalists were not the only ones who felt heavily burdened; the

\footnotetext{
${ }^{189}$ TSP, 4:208.

${ }^{190}$ TSP, 4:208.

${ }^{191}$ TSP, 4:209.

${ }^{192}$ TSP , 4:208, 211.

${ }^{193}$ TSP, 4:209.

${ }^{194}$ TSP, 4:189; CSPD, 9:70, 154.

${ }^{195}$ TSP, 4:293.
} 
major-generals found their tasks onerous. The foot-dragging and reluctance to pay-in addition to the amount of work required by the tax — seems to have worn the commissioners down over time. For the officers, the most irksome aspect of the plan was the difficulty in generating enough revenue. In many districts the problem was that there were not enough Royalists above the income threshold. Haynes wrote that after only ten days "they have given summons to almost all wil be quallyfied to bare any part of the charge; and the greatest part of them have they affected, and that will be the greatest care they could possibly, exceeding in their assessing the books of sequestration." In other words, he had run out of people to whom he could apply the tax. The only possibility he saw for generating enough to pay the militias was to tax all who had been involved in the rising of 1648, which would clearly have violated the provisions of the Act of Oblivion of 1652. ${ }^{196}$ Boteler commented early on in his work that there were few delinquents in the county of Bedford to decimate. ${ }^{197}$

On account of the limited tax base, Major-general Thomas Kelsey, who worked in Kent and Surrey, suggested lowering the threshold to $£ 50$ of annual income in which case "we should raise almost as much more in this countie as now we shall doe." His commissioners were also dissatisfied that "soe many should scape, as will by that means." 198 The ever-enthusiastic Boteler and his commissioners wrote that the charge should be levied on those with $£ 20$ per annum or $£ 300$ land value, otherwise too many would escape punishment. Also, the lowered threshold would "add considerably towards

\footnotetext{
${ }^{196}$ TSP, 4:216.

${ }^{197}$ TSP, 4:218.

${ }^{198}$ TSP, 4:225.
} 
the maintenance of the militia forces, which with us falls short of our expectations."199 Considering the importance of the program, Kelsey's suggestion at least seems reasonable. But the government did not accede to these requests. Though money had to be shifted from county to county to pay for those that did not raise enough, the threshold of the tax remained stable for the duration of the scheme.

The threshold of the tax does seem rather arbitrary. Central government did not announce its reasons for cutting off the tax at $£ 100$, but its advantages are not too hard to fathom. Taxing only those at the top would have been more efficient in terms of manpower. Lowering the qualification would have affected - or threatened to affect-a larger portion of the populace and therefore have generated wider resentment. Also, those at the top were more likely to have been ringleaders of the rebellion. Thus, they were more deserving of punishment and more likely to be more in need of the stern warning the punitive element of the tax provided. The Declaration outlined one of the aims of the tax as to "terrify men from such attempts in the future." 200 So to a degree such a limitation on the scope of the tax made sense.

Yet the tax set the government up for trouble in their relations with local authorities and the electorate. By targeting those at the top, the council had failed to take into account that it was those most liable to the tax who also wielded the greatest power in the localities. The wealthiest were at the top of the patronage pyramid, a social edifice which was weaker than it had been in the early sixteenth century but which had certainly not collapsed. The Protectorate might tax those higher-status delinquents and preclude

\footnotetext{
${ }^{199}$ TSP, 4:235.

${ }^{200}$ Declaration, 36.
} 
them from standing for election. But because the strongest networks in English society were horizontal rather than vertical, friends and fellow gentlemen of those who were taxed would still have opposed it. Cromwell seemed to be aware of this, and he repeatedly indemnified those of the greater gentry or of peerage rank who applied for relief. $^{201}$ Many of the major-generals saw the granting of this relief as an injustice, protesting that many enemies escaped the punishment provided by the tax while the militias were deprived of the additional funds that a more strict application of the tax would have provided. ${ }^{202}$ Yet their lack of appreciation for the political and social realities of the nation would lead to their undoing.

\section{Popular praise}

It seems surprising that a program of such importance and concern to the Council would not have been better thought out. The lack of forethought regarding the implementation of the means of taxation also suggests a significant lack of forethought regarding the possible reaction to the tax, which smacked of the extra-parliamentary revenue schemes reminiscent of Charles I. As observed in the Declaration, the council had clearly thought through the benefits and justification of the program and its Royalistonly tax, but they had apparently not noticed the decimation tax's resemblance to previous absolutist practices-practices which had in the 1630s alienated the gentry and unwittingly helped to create the resistance that contributed to the outbreak of Civil War. $^{203}$

\footnotetext{
${ }^{201}$ CSPD, 9:152, 157.

${ }^{202}$ TSP, 4:550. Perhaps Cromwell considered that their entreaties to his person were sufficient evidence of their "change of heart."

${ }^{203}$ Worden, ECW, 133.
} 
Historians have tended to see the major-generals as hated by the populace for their interference in festivals and the suppression of alehouses, both sources of popular amusement. Yet the presence of the major-generals, so maligned after their "rule," was enthusiastically welcomed by many of the "common sort" when they arrived. ${ }^{204}$ A rebellion was obviously a threat to central government, but it was also a danger to the common people, many of whom would have remembered the frightening disorder of the Civil Wars and hoped for anything but a return to such conditions. There were significant reports of the people being frightened by ominous political events, and the constant rumors of further plots by Royalists, Fifth Monarchists and Levelers would have done nothing to reassure them. ${ }^{205}$ John Clarke wrote to Haynes in Colchester from Bury St. Edmunds begging for help. "We are in a naked condition, and the grouth of Papists is greate in this towne." ${ }^{206}$ And not a few were averse to the Royalists, happy to see them suffer for their disloyalty to the state. An observer of the Penruddock trials reported that "the people here are well-pleased by these proceedings."207 The opinion of the godly in the counties during the trials was that the Royalists were insolent and "so much hardened that they are like Pharaoh." ${ }^{208}$ Against those "hardened" Royalist enemies, the godly needed some sort of additional defense.

For those "well-affected" to the government, the major-generals and the militias they commanded would provide that additional security. In a letter from Norfolk after Penruddock's rising, William Sheldrake complained that "Here there is much enquiry

\footnotetext{
204 "Common sort" was the early modern term for ordinary people.

${ }^{205}$ TSP, 4:152, 311, 699.

${ }^{206}$ TSP, 3:236.

${ }^{207}$ TSP, 3:398.

${ }^{208}$ TSP, 3:398.
} 
about the militia, and many wonder why it goes not on; for wee seeme soe naked and unfitt, uppon occasion, to doe any service." ${ }^{209}$ Once the major-generals arrived in the localities and the militias were formed, the "well-affected" would express their gratitude. Worsley reported that "I have bene in divers tou[w]nes, and have acquainted them...with the good people, who doth noe little rejoice, and seem to be abondantly affected therewith." 210 The commissioners in Bedford expressed the view that their work was for the benefit of the country because it helped in "settling the hearts and quieting the minds of all good people by this course now proceeded in." ${ }^{211}$ Naturally the major-generals would have a tendency to express positive sentiments regarding work they felt was so important, and specifically, so important to Cromwell and the Council. But the majorgenerals and their commissioners who corresponded with the Council went beyond that, expressing a general feeling that, despite initial fears and misgivings, a significant section of the general population was in favor of their presence and purposes.

\section{The gentry and local power}

Yet the most populous sector of society was certainly not the most powerful in the seventeenth century. The major-generals did not go into an environment characterized by a power vacuum. Though it had been shaken and shifted by the experience of Civil War, the gentry-led social structure of the localities was still very much intact and had in many ways been strengthened. ${ }^{212}$ As mentioned in the introduction, in governance the gentry were represented by the JPs, or justices of the peace. Some important members of the

\footnotetext{
${ }^{209}$ TSP, 3:328.

${ }^{210}$ TSP, 4:179.

${ }^{211}$ TSP, 3:207-8.

${ }^{212}$ Derek Hirst, "The Failure of Godly Rule in the English Republic," Past and Present 132 (August 1991): 50.
} 
gentry chose not to sit on the benches, but those who took their places did so as a matter of pride, power, and position; they were the masters of the localities, though within the limits of law. They were concerned with order, but they were not accustomed to taking orders-especially those from outside the counties and outside the traditional elites. ${ }^{213}$

The major-generals were not sent into the counties as a replacement for local authorities; instead, they constituted an additional power structure which was placed alongside the traditional one. In fact, both the JPs and the major-generals received their commissions from the Council and the Protector. As part of their duty as men commissioned in their offices by the state, the local authorities—JPs, sheriffs, bailiffs, and the aldermen and burgesses of the towns-were required to assist the major-generals in their duties, as directed in the commissions of the major-generals referenced above and in other directives as well. ${ }^{214}$ As they worked in the countryside the major-generals and their assisting commissioners necessarily came into contact with the local authorities of the towns and shires. They were sent into the localities with specific objectives, but some of their tasks concerned matters which had traditionally been solely under the supervision of local authorities, which created opportunities for conflict. ${ }^{215}$

The relationship between central government and the localities was in constant flux during the early modern period, and it was a relationship characterized by both

\footnotetext{
${ }^{213}$ The importance and power of the office of justice of the peace, or JP, is discussed in detail in: Fletcher and Stevenson, 1-40; Fletcher, "Local Officeholding," 92-115; Fletcher, Reform, ch.1, 5; Herrup, 6-7, 4962. state.
} 
negotiation and resistance. ${ }^{216}$ In a sort of loop of power, central government asked the localities to implement their directives, while the localities asked central government to enact and engage in policies which would promote the interests of town, county, and local elites. The primary means by which the localities influenced and exercised power involving central government was through Parliament, without which they were at the mercy of the crown. Charles I attempted to rule without the limitation to crown authority that Parliament guaranteed, and because he infringed on their authority, Parliament went to war to limit his. Yet the struggle went back to long before the conflict with the first Charles Stuart and his ministers; central government had long attempted to impose its will on the nation and its shire elites, and time and again local government had managed to resist. This tug-of-war was characteristic of the court-country relationship throughout the early-modern period, and to some extent the insertion of the major-generals was another chapter in that struggle. ${ }^{217}$

As with any other initiative from the center, local authorities could assist or resist as they chose. ${ }^{218}$ Indeed, one of the possible reasons why the major-generals were inserted into the localities was to do or encourage to be done what the local authorities had not done. ${ }^{219}$ The way the military officers interacted with local officials is an important reflection of the intentions of the Interregnum government toward the localities, and how they dealt with local office-holders reflected the Council's attitudes

\footnotetext{
${ }^{216}$ Ivan Roots, "The central government and the local community," in E. W. Ives, The English Revolution, 1600-1660 (New York: Barnes \& Noble, 1969), 34-41; Fletcher and Stevenson, 38-9; Fletcher, Reform, 60 1.

${ }^{217}$ Roots, 34-41.

${ }^{218}$ Fletcher, Reform, 5-19; Fletcher and Stevenson, 16-17; Herrup, 200-201; Roots, 34-41.

${ }^{219}$ Underdown, "Settlement," 175.
} 
toward those localities. The major-generals' attitudes would also influence how local authorities would react to them, and that reaction would be an important factor which impacted the major-generals' effectiveness and their long-term chances of success.

\section{Major-generals and local officials: a crucible for conflict}

Some of the major-generals had been active in dealing with civilians in towns and shires before they took their commissions for "securing the peace of the Commonwealth." One of those was then-major William Boteler, who became somewhat notorious for his supposed severity and harshness during the years when he served as a major-general in the Midlands. ${ }^{220}$ Yet in late 1654 , prior to his commission as a majorgeneral, he was sent by central government to investigate and resolve a dispute in Bristol. How he dealt with local authorities indicates that he was anything but a petty tyrant or advocate of arbitrary government.

The Council of State had apparently received complaints from some godly men in Bristol, England's second largest town, that the local officials were treating them poorly. The entreaty for assistance was convincing enough for Cromwell to send then-Major William Boteler to investigate. After he arrived, Boteler listened as the deputies of the castle and others declared "their sadd grievances" regarding the alleged mistreatment of the godly by the magistrates and public. The local petitioners spent two hours "heaping one complaynt upon another against" while Boteler listened. The next day when the complainers came to him again, the major decided to convene a meeting between the antagonists after having also hear the mayor and his aldermen protest their innocence. Two of the leading petitioners for support from the Protector refused to come, saying

\footnotetext{
${ }^{220}$ Durston, 45-46.
} 
they had asked Cromwell if he would be "pleased to send some strength hither to secure the interest of the commonwealth." ${ }^{221}$ Apparently, it was not enough for Boteler to hear them out; they had expected swift, harsh action against their opponents.

At the meeting, which included the chief army officers stationed in the town, Boteler heard the grievances against the townsmen one by one. He wrote afterward of the accusations that "not one of them could be proved against or fastened upon them." Rather than taking issue with the local authorities, he felt "grief and shame" regarding the conduct of the army men who by their behavior presented a danger to the godly cause and the reputation of the Commonwealth itself. His overall impression of the officers was that they had "carried things very imprudently, and to the dishonor of relligion and your highness, and army; and I must needs say that it hath beene onley the goodness of God, that such carriages have not begotten more animosyties from this people." Additionally, Boteler reproved one of the officers for his complaints, for the indiscreet nature of his speech and for carrying on in a way which was "half quaker.",222 The fairness of Boteler's behavior was attested to by local Baptist businessman James Powell and an alderman of the town who had served in the First Protectorate Parliament, Robert Aldworth, who were both supporters of the government. ${ }^{223}$

The cause of the conflict, based on the letters of Boteler and Powell, was the feeling among some of the godly that they were not being properly favored and defended by the magistrates. Powell traced the conflict back to the election of a burgess which did

${ }^{221}$ TSP, 3:169-172.

${ }^{222}$ Boteler also wrote that the Quakers had been responsible for many disturbances and for upsetting people throughout the town. ${ }^{223}$ TSP, 3:169-172; Durson, 64. 
not turn out as the Independent party would have preferred. But having investigated, Boteler refused to intervene against opponents of the Independent "party" who he felt were blameless. That the future major-general was loathe to side automatically with the godly in a dispute with other local authorities indicates a degree of restraint that belies the negative reputation that the major-generals gained in 1656. The episode also exemplifies the potential of elections, and other public events, as occasions when simmering conflict could boil over into open, acrimonious dispute-something the government did its best to avoid.

In a subsequent letter Boteler informed the Council of State that he had relayed Cromwell's appreciation to the Bristol authorities for the magistrates' "patient spirit toward good people," affirming his belief that they had acted in good faith to all who were reasonably godly, a core Independent belief. Boteler and the Protector's faith in the local administrators was vindicated when two days after Penruddock's rising the Bristol council declared its loyalty to the Protector against "Charles Stuart, cavaliers, levelers, and all other opposers of the publique peace." 224 They had been dealt with reasonably, and they returned the favor with their loyalty. It seems unlikely that after the rising of 1655 the major-generals would have dramatically changed their general attitude toward local authorities. Rather, any peremptory actions the major-generals took were against locals generally but only convinced Royalists who presented an actually danger to the state. Those who were well-affected could generally depend on the government's support. However, the episode does show the potential for conflict between the army major-generals and local town or county officials such as the JPs. Had Boteler not been ${ }^{224}$ TSP, 3: 231. 
as moderate and careful, the embarrassing behavior of the Bristol commanders could have turned the losers of a local factional struggle into fervent opponents of the government.

When the major-generals - as major-generals (and not in their previous ranks or positions) - began their work in the shires in late 1655, they generally showed themselves to be as unaggressive toward local authorities and as uninterested in "lording it over" local councils or JPs as Boteler had been in the Bristol dispute. They were there, though, to put the Council of State's plans into practice, and so they were required to evaluate the helpfulness of local authorities and enlist their assistance as best they could. One task for which the major-generals would look to local authorities for help regarded possible additions to the often too-short lists of named commissioners.

In November of 1655, just after the army officers had been invested with their new authority and taken up their new posts, Major-general Goffe in Sussex wrote to Thurloe that he had considered putting one of the local justices into the commission, but despite the man's protestations of willingness to help, Goffe decided against it. "Coll. Morley saith, any thing he cann assist mee in, as a justice of the peace, he will doe to the utmost." 225 Yet after further detailing the aims of the program, Goffe felt that Morley began to feign ignorance to avoid having to provide further assistance. Two other men, possibly justices, were also left off of the commissions because Goffe had been told they were "lately observed to be too gratious with disaffected men."

The information about their loyalty was most certainly provided by the local wellaffected godly, on whom the major-generals, as outsiders, regularly had to rely for ${ }^{225}$ TSP, 4:160-161. 
advice. The "disaffected" were usually Presbyterians, republicans, or others who found Protectoral or non-monarchical government distasteful, or they could have been former Royalists as well. The nature of Morley's "graciousness" is not possible to discern exactly. But considering his place in the social order as a JP, the "graciousness" to which Goffe refers could simply have been based on Morley's mending fences with his and the government's former enemies. This was probably an example of the "healing and settling" among the gentry, whose bonds within the gentry class—-shredded during the Civil War-were being renewed. ${ }^{226}$ Early in the Civil Wars, the local population, especially the gentry, had been all too interested in settling scores. Yet after a long period of strife and a short one of peace, the desire to avoid further trouble with fellow local notables was greater than the desire to help unknowns sent from the outside.

Additionally, many JPs would have been reluctant to help because of the unpopularity inherent in the tasks, especially administering the decimation tax on their social equals. This could be yet another clue to the puzzle of why the major-generals and the attendant commissions eventually gained a bad reputation: only the most fervent would have been willing to serve on the commissions. The major-generals generally aimed to practice moderation and be reasonable with moderates. But moderates might have assumed the major-generals were radicals because of the local reputations of those who assisted them in the commissions.

The major-generals thus looked to enlist local authorities in their work, however selectively. In some instances, however, local authorities reversed the helper-helped relationship, enlisting the army officers to help them in local power struggles. Soon after

\footnotetext{
${ }^{226}$ Underdown, "Settlement," in Aylmer, 172-175.
} 
arriving in his district, Major-general Whalley met the Coventry Town Council and began looking into a matter which the Coventry Council seems to have previously brought to the attention of Whitehall. The meetings went well, and in a letter to Thurloe, Whalley expressed his belief that the aldermen and mayor were as enthusiastic regarding the government as those of any other town. Whalley reported that he had sent for a local alderman and previous mayor, a Mr. Chambers, who had apparently been causing trouble in the local Council, and while they awaited his arrival Whalley and the aldermen heard testimony by "diverse godly men” against Chambers. A few days later Chambers appeared before the Town Council and Whalley. Chambers quickly asked to be dismissed from their presence, presumably to avoid hearing or suffering any punishment. The Town Council then quickly ejected Chambers from all of his offices, a move which Whalley said "struck the worser sort with fear and amazement."227

The aldermen had used the presence of the major-general to assist them in the elimination of an opponent, something they had certainly been planning for some time. Whalley clearly did not know enough about the town and its politics to make an informed judgment on the rightness of the matter, but he seemed satisfied that the godly on the Coventry Council were very pleased. He wrote to Thurloe that the local power play made "the hearts of the godly" in the city rejoice at what had occurred. ${ }^{228}$ However much the pro-government party was pleased at the expulsion, it would have done little to gain the admiration of either the magistrate-who as a former mayor would have pulled significant weight in the town-or those his allies. The action in favor of the godly on

\footnotetext{
${ }^{227}$ TSP 4, 272-3, 284.

${ }^{228}$ TSP 4, 272-3, 284.
} 
the council might have "terrified" the opponents, but it would have done little to endear the regime to moderates voting in subsequent elections. Settling a score pleased those who benefitted at the time, but for moderates it would have been one strike against the major-generals.

Whalley also became involved in an internal dispute with the local administration in Lincoln. To help resolve it and future difficulties of the sort, he wrote to Thurloe with a suggestion: augment the power of the major-generals.

I renew the request; and likewise that the major generals may bee constituted justices of the peace in the severall and particular counties and corporations given them in their charge; for I find it very needfull. I was forced at Lincolne, for the composeing of a long and hot difference there betwixt the mayor, aldermen, and citizens, to assume a little more power than (I thinke) belonged to mee; and I hope God hath made major general Berrey and my selfe instruments to reconcile them, and to settle their government. $^{229}$

Again, one of the major-generals was being asked to intervene in local affairs—or at least thought that he had been - and he asked to be made a JP to handle the dispute. As before, Whalley does not seem to have been directly imposing his will on the local authorities but rather "helping" to mediate a dispute. Though the details of the outcome were not forthcoming, just as in the previous spat in Coventry, there would have been winners and losers. But consistently coming in on the side of the godly would have been unwise in the long term. These are the kind of matters which would have earned the major-generals a reputation for overstepping their authority, trampling on the toes of the traditional elites, and instituting "tyranny," or arbitrary government which violated the privileges of the people. For the "well-affected" the presence of the major-generals was a blessing; for

${ }^{229} \operatorname{TSP} 4,197$. 
moderates or opponents it was yet another example of how the government was siding with their enemies.

\section{Order and disorder-and the major-generals}

Though they could unwittingly be pulled into struggles, the major-generals were also willing to intervene if locals demonstrated a lack of vigor in fulfilling their duties. In Lancashire, Major-general Charles Worsley expressed his dismay at the disorderly state of the towns. He wrote to Thurloe saying that the constables in the marketplace were "swearers, and drunken idle persons themselves." He blamed the problem on the local magistrates, saying the disorder was "much ocationed by the want of good justices. ${ }^{, 230}$

Though the constables were directly responsible for enforcement, the slackness regarding enforcement duties did likely indicate the county's lack of JPs and judicial officers enthusiastic about the government's aims. Lancashire had long been Royalist, and but for an enclave involved in the cloth trade, it traditionally had not been a bastion of moral reformers. But the ungodliness of the county had come under significant pressure after the first Civil War. Once parliamentarians gained control of the county, there was a very significant increase in prosecutions for order offences. But as the late 1640 s passed into the 1650 s, this pressure on disorder offences subsided. ${ }^{231}$ In 1656 , Worsley complained of the constables, who were invariably men pressed into their duties as a matter of community obligation from the low-to-middle social strata. It was usually JPs' prosecution of lazy constables that resulted in more prosecutions, so a slacking off

\footnotetext{
${ }^{230}$ TSP, 4:278.

${ }^{231}$ Wrightson, "Two concepts of order," 37.
} 
by JPs in calling to account less assiduous constables would have allowed enforcementparticularly of minor moral offences - to slip back to its pre-Civil War levels. ${ }^{232}$ Thus the reduction of prosecutions for those order offences could indicate that justices who had been precluded from serving were slipping back in, and thus the blind eye formerly turned toward the disorder of moral peccadilloes was being applied again.

Having had some contact with the local justices, Worsley was likely in a position to have evaluated their enthusiasm or lack thereof regarding the furtherance of order. ${ }^{233}$ The interest by the major-general does not, however, indicate a desire to tyrannize or exercise arbitrary authority on the populace. Rather, it reflects the officer's frustration at the unwillingness or inability of justices and lower-level officeholders to fulfill their duties. Worsley's observations indicate something else regarding enforcement of social order, as well: the difficulty inherent in effecting a complete social overhaul at the microscopic level with limited resources. If the very officers of the law were committing the offences deemed objectionable, it seems unlikely that their enforcement efforts would have been successful without significant pressure from above or a massive infusion of manpower. Yet the major-generals were given a job, and they did their best to do it, whether or not the social mores of the time were in accord with their aims. But again, Worsley's desire to bring offenders to account was not part of an effort to establish arbitrary government. It was in the pursuit of good order.

\footnotetext{
${ }^{232}$ Wrightson, "Two concepts of order," 39-45.

${ }^{233}$ TSP, 4:78.
} 
The 1655 rising was unsettling, and afterward there were continued rumors of further risings. ${ }^{234}$ Plots against Cromwell came to light in London. Disorder seemingly threatened to rear its head. Letters from around the country are full of concern, particularly for the godly people. There was a sense that something had to be done to keep the nation from descending into disorder. Yet, despite the fact that social disorder was a problem in the counties, there was nothing like the chaos seen previously during the wars. John Morrill and John Walter have cast some doubt on the pervasive claims that the country was overcome with chaos, arguing that much of the "panic" was based on "the reporting of good copy directed at an anxious public fearfully greedy to learn about new disturbances. ${ }^{235}$ But the two historians noted that there was a pervasive fear of disorder which itself constituted a serious political problem. ${ }^{236}$ A state was only as stable as its people believed it to be, and the downward spiral resulting from the perception of disorder led to doubts regarding the permanence and stability of the Protectorate itself. With these fears in mind, it makes perfect sense that a main reason the major-generals were sent into the counties was to increase order.

Prior to the Civil Wars, minor moral and social-order offenses had mostly been dealt with by ecclesiastical authorities, who had always been considered an essential prop to order. But during the Interregnum the church had been partially disestablished and its courts abolished. Therefore, it could no longer provide the same sort of social monitoring

\footnotetext{
${ }^{234}$ Josselin, 337, 340-1.

${ }^{235}$ Morrill and Walter, 147. Though fears were greater than the actually level of disorder, the two agreed that the period did have elevated levels of disorder in the Civil War period.

${ }^{236}$ Morrill and Walter, 158-164.
} 
that it had when the ecclesiastical courts were functioning. ${ }^{237}$ Indeed, perhaps the perceived increase in ungodliness had to do with the absence of the watchful presence of the traditional church authority. But JPs were either already too overtaxed by a heavy workload to pick up the slack ${ }^{238}$ or perhaps simply unenthusiastic about doing the work previously done by the parish priest. Without the ecclesiastical courts, something was needed to fill the church's role in maintaining order. So rather than constituting something new, as some historians have often argued, ${ }^{239}$ the push for "godly" reform and social order by the major-generals can reasonably be seen as little more than a rather ineffective substitute for the church court. Additionally, for the government that sort of influence on society was important because it helped prevent disorder on a larger scale.

Norwich was one of the largest towns in England, and was thus the sort of area where problems with disorder — and rebellion—might have arisen. One of the commissioners there, Colonel Robert Jermy, wrote to the Protector expressing gratitude for what he and his fellow commissioners saw as the benefits of the major-generals' scheme. When considering what his efforts and those of his fellow commissioners were contributing to the country, security and reducing disorder were foremost in Jermy's mind. He expressed to Cromwell his joy in "securing...the peaceable enjoyment of their dear and dearly bought liberties, so much envied at by that generation of men." He went on to say that the commissioners were thankful that the "present peace doth from God, under your highness, reach forth unto us; wherein we shall be most glad to be accounted"

\footnotetext{
${ }^{237}$ Ingram Martin, Church Courts, Sex, and Marriage in England, 1570-1640 (Cambridge: Cambridge University Press, 1987), 1-4.

${ }^{238}$ Fletcher, Reform, 87-90.

${ }^{239}$ Durston, 7-10.
} 
in the face of evidence that "our enemies awake...united unto new attempts." Jermy also expressed his distaste for the nature of a portion of the work, likely meaning the decimations, which he called "so unpleasant a theme." Yet he hoped that it would incline their enemies to reconsider their errors and "with heart and hand join together to keep and thankfully improve those many blessings.. 240

For Jermy, Cromwell, and the Council, taking open measures to increase security by adding personnel on the ground was simply a way to assure people in the localities that the government could indeed keep them safe from invasion (a particular concern in seaside areas), rebellion, and the disorder that they feared and perhaps felt in their daily lives. The major-generals and their commissioners were there to suppress disorder that threatened the government and disturbed the people in the localities. Evidence of their success or failure in this endeavor can be found in the records of the counties they tried to secure.

\footnotetext{
${ }^{240}$ TSP, 4:171.
} 


\section{Chapter Three}

\section{Order, Major-generals and the Justices of Essex}

[He] is a common barrator and a daily and public disturber, and also a common chider, brawler, fighter, slanderer and sower of seditious strife and discord among his neighbours. ${ }^{241}$

Indictment of Edward Deane of Rochford, saddler, Essex General Quarter Sessions of the Peace, January 1655.

The major-generals went into the localities to rid them of disorder and the potential for rebellion. They were daunted but optimistic in their task. But what impact did they have? How much did their efforts matter and to whom? The officers must have had some significant impact, because barely a year after their commissions went into effect their hopes for perpetual sanction were dashed by the defeat of the Militia Bill in January 1657 during the Second Protectorate Parliament. ${ }^{242}$ Strangely, the bill was voted down after particularly acrimonious debate in a Parliament whose membership had been selectively culled by the Council of State. In other words, a Parliament largely selected by the Council voted down the Council's pet project. That lack of support demonstrates

\footnotetext{
${ }^{241}$ Indictment of Edward Deane of Rochford, saddler, Essex General Quarter Sessions of the Peace, January 1655, as quoted in ERO, Q/SR 363/13.

${ }^{242}$ Smith and Little, 109-111.
} 
the depth of opposition by the gentry—even the well-affected gentry - to the majorgenerals and their work. This chapter will explore the reasons why that opposition was so strong, and part of that exploration will entail looking at the order-enhancing work of both the major-generals and the local JPs, from whose ranks the MPs who voted down the Militia Bill were picked.

Many reasons have been cited for the defeat of the Militia Bill, a defeat which spelled the end of the government initiative sometimes called the "rule of the majorgenerals." One common reason given by historians for that opposition was the localities' resentment of "godly reformation" and the supposed imposition of arbitrary government, or "tyranny" as it was then sometimes called, on the nation. According to this view, the religious factionalism of the time combined with army power to produce a sort of localized theocratic despotism that no Parliament—of freedom loving Englishmancould countenance. Yet there is reason to believe that there was little general tyranny and even less effective godly reformation. If that was the case, then the distempers which arose in response to the major-generals would likely have had other causes.

Early historians and post-Interregnum commentators seemed sure that the majorgenerals imposed harsh, arbitrary government, but their testaments are rather dubious and were often politically motivated. Diaries, speeches, and other commentaries from those involved in the political realm are important sources, but those accounts are often very biased. Sources touching on the Interregnum are often particularly prone to such bias because they were produced during the Restoration, when the political and literary nation was dominated by those who returned to power after being defeated during the Civil 
Wars and excluded from government during the Commonwealth. One wonders if it was even possible to publish or to be active politically and socially without excoriating those who killed one king and repeatedly defeated in battle the one who would be restored. In the decades and centuries that followed the Restoration, those biases would continue. Cromwell and his supporters were everywhere vilified as tyrants, to the extent that even Robespierre, following the Great Terror in which thousands were put to death for political reasons, assured the people of his good intentions and mild measures by swearing that he was "no Cromwell." 243 In his funeral oration for Henrietta-Maria, queen of England and wife of Charles I, Jacques-Benigne Bossuet further propagated the myth of the Interregnum state's badness, saying Cromwell was "as subtle a hypocrite as he was a consummate politician...one of those active and audacious spirits who seem born for the disturbance of the world." ${ }^{244}$ Commentary sources are also very limited in terms of not merely political but social representation. It is not merely that they do not represent the lowest classes but rather that they do not even represent a particularly wide spectrum of the propertied or gentry classes. It is possible to use these sources to pluck out underlying information, but generally these sources have been employed to substantiate hypercritical views of the Interregnum government and its initiatives. In the eyes of such

\footnotetext{
${ }^{243}$ Maximilien Robespierre, "Report on the Principles of Political Morality (5 February 1794)," in John W. Boyer, Julius Kirshner and Keith Michael Baker, eds., The Old Regime and the French Revolution, vol. 7 of University of Chicago Readings in Western Civilization (University of Chicago Press, 1987), 369. ${ }^{244}$ Jacques-Benigne Bossuet, "Funeral Discourse Upon Henrietta Maria, Queen of Great Britain" (extracts), in Panegyrics of the Saints, D. O’Mahoney, ed. (London: Kegan Paul, Trench, Trubner and Co., 1924), 228-9.
} 
commentators, rebels were rebels, religious fanatics were fanatiks and schismatiks, and Oliver Cromwell and his army officers were tyrants and "silly mean men.,"245

It is therefore useful to turn to other sources which were recorded less for the purposes of vilifying the Commonwealth, settling scores, and proving one's undying admiration and loyalty for the monarchy. So to determine whether the major-generals engaged heavily in those reforming activities mentioned by some scholars-and thus perhaps caused their own demise with their godliness-it is necessary to look for evidence of their work in other sources. The major-generals worked for central and with local government, whose job it was to ensure order and maintain the "common peace." So one place to look for evidence of the major-generals' work is in the records of government, especially those of the localities. There one might expect to find evidence of their work, particularly because the major-generals were required to mete out punishment of local offenders through the local courts.

In particular, these documents can reveal alterations in local judicial practices and outcomes around the time that the major-generals and their commissioners were active in the communities. But they also are very useful for understanding the mindset and priorities of those whose responsibility it was — and long had been — to govern and administer the shires. The court records contain a truly amazing wealth of material regarding the behavior and values of the people of the English countryside. Through these records it is often possible to gain a better understanding of how the English population lived and how the authorities ruled them. The nature of court sources often

${ }^{245}$ Lucy Hutchinson, Memoirs of the Life of Colonel Hutchinson (London: Oxford University Press, 1973), 209. 
has to do with what might be called social deviance rather than everyday behavior. But for the subject at hand they are particularly useful, for the activities of the local justices and the men and women that came before them concern precisely the activities which the major-generals aimed to reform in pursuit of fulfilling their duties to ensure peace and order—or "godliness"- and the underlying conditions which might give rise to rebellion. ${ }^{246}$ As mentioned in the previous chapter, the main concern of JPs in the counties may have been consolidation and maintenance of their positions as leaders of the shires. ${ }^{247}$ But there was also a deep desire to promote social order and a pervasive fear of its opposite, disorder. JPs and other local officers were installed in their offices by the "commissions of the peace" and they were expected to ensure relative communal tranquility as a primary end of their offices. Yet they were also given a variety of other administrative tasks. In either case, looking at the tasks they performed and how they performed them shows what was happening in the shires and reveals a good deal about what the justices thought good order and good government meant to the people of England in the 1650s. Records of crime and administration tell us much about elite values, what JPs thought was best for their communities, and what they perceived to be a threat to order and peace.

Disorder is a breakdown in adherence to the rules that govern social life in a community; authorities feared that disintegration of that order on a small scale might lead to breakdown on the grand scale. The result: rebellion could ensue, or so it was thought.

\footnotetext{
${ }^{246}$ The analysis of courts and their usefulness in revealing the social world of the people and justices is informed by these authors who provide further discussion of this topic: Herrup, 2-5, 49-62, 158-168; Sharpe, 3-14; Brewer and Styles, 11-20; G. R. Elton, "Introduction: Crime and the Historian," in J. S. Cockburn, Crime in England, 1550-1800 (Princeton, N.J.: Princeton University Press, 1977), 1-14. ${ }^{247}$ Herrup, 49-55.
} 
"If we must beware of exaggerating the scale of disorder, we must also beware of understanding how the fear of disorder filled the hearts and minds and affected the actions of those in authority." ${ }^{248}$ Both the justices of the peace and the central government seemed to agree that there was an excess of disorderliness in the country in the 1650s: rebels threatened and, following a period of the most extreme disorder—civil war-the people were restless and uncontrolled. In the Interregnum, "the government's sense of its own insecurities encouraged it to read into reports of often minor disorders 'the beginnings of insurrection'. ${ }^{249}$ The structures the JPs had come to depend upon to secure order were not functioning properly, and it was up to the government to reinvigorate them. Assigning local enforcement duties to army officers and their commissioners was simply one way—albeit a very direct, novel, and semi-constitutional way—of improving that order.

The raising of the horse militias was one element of the solution, though the horse troops were intended more to deal with large-scale disorders, meaning invasion or risings in the name of the late king or his son, than locally confined disorders. So for day-to-day social disorders it was generally thought best to strengthen the established mechanisms for keeping peace in the localities: local justice. Traditional measures had always been seen as essential to good order, and local authorities during the period seemed inclined to turn to them again to restore peace. Central government also appealed to these authorities to assist them in this aim. Yet, since the outbreak of rebellion, central

\footnotetext{
${ }^{248}$ Morrill and Walter, 163.

${ }^{249}$ Morrill and Walter, 145.
} 
government had found them wanting: JPs were not doing enough. ${ }^{250}$ Something had to be done to address these issues — or so it was thought, at least. So the major-generals were sent out into the localities, not so much to improve "godliness" as to assist in the maintenance of order, with additional tasks being added to their original commissions to allow them to work with JPs in "keeping the peace." Clues to the story of whether the major-generals had any significant impact on efforts to improve order can be judged by looking in the pages of the local court records.

It might be obvious, but the justices ruled the localities and enforced its values largely by controlling the penalties for disobedience to the law. Applying the full force of the law was actually very rare. In most cases the penalty for violating the community's moral and social order codes was often little more than a recognizance on a promise for good behavior, though in others JPs might choose to set an example for the community and the perpetrator by demonstrating the potentially painful consequences of breaking the law. In some cases enforcement entailed moving the matter to a higher court, either by allowing the accused to transverse the verdict—which meant that it would be heard in London-or by binding the matter over to the twice-yearly assizes where it would be dealt with by those who might inflict the ultimate penalty criminals could face. Whatever the means and the measure, the justices were mostly concerned with getting the desired result: good order.

Over the preceding century, the burden of ensuring order and good governance in the localities had been progressively shifted onto the shoulders of the justices. The justices did their work primarily in two venues. The first was in their local corners of the ${ }^{250}$ Underdown, "Settlement in the Counties," in Aylmer, 175. 
county, where they would respond to matters as they arose and were brought to the justices' attention by a constable or member of the public. These were the petty sessions, and only one or two justices were required to conduct them. In these very small and personal courts, the justices would deal with many minor matters. If an offense was serious enough it could be bound over to the next general quarter sessions of the peace, a quarterly meeting attended by all available justices of the county where matters could be addressed based on the combined expertise and consensual opinion of a number of their local judicial peers. These meetings, which generally lasted for a few days, were occasions where justices could discuss not only their cases and judicial matters but also the most important matters regarding the country and the nation. They were justifiably called the "parliaments of the shires," not only because justices from all over the county would collectively decide on matters that came before them, such as how to distribute the cost of major bridge repairs, but also because the opinions derived from and expressed at the sessions represented the collective elite political consciousness of the locality. It was at meetings such as these that all matters of concern to the most important men in the shire were discussed, often including who would stand for Parliament. ${ }^{251}$

The other important judicial meeting was the assizes, which were bi-yearly circuit courts which were presided over by one or two justices appointed by central government who would try cases (including the most severe ones involving the death penalty), review the work of local justices from the quarter and petty sessions, advise JPs on judicial matters, and deliver instructions regarding central government's expectations of the JPs

\footnotetext{
${ }^{251}$ Fletcher, Reform, 87-115.
} 
and the implementation of policy. The assizes were a vital connection between the center and the shires, particularly before Parliament began to meet annually. ${ }^{252}$

The JPs may have been the most important men in the shires, but they were not paid for their efforts. The seventeenth-century local governmental system was almost entirely staffed by amateurs, many of whom were pressed into service in their parishes on a rotating basis. ${ }^{253}$ The difficulty of being a constable indicates a good deal about the priorities and function of the apparatus of local administration. All able-bodied men in the parishes below the gentry served as constables on a rotating basis. Their job was to keep an eye on things, and if wrong was done, they were to confront it and bring it to the attention of a justice of the peace. Yet not surprisingly, as Major-general Worsley commented regarding Lancashire, the constables were not always especially enthusiastic about their duties. Sometimes that reticence was not to do with laziness but rather the dangers constables could face. The court sessions rolls reveal regular indictments or recognizances of those who objected enough to a responsible constable's intrusion to make him suffer for his assiduity. The county sessions of 1654 tell the story of Sampson Tibbals, a locksmith of Newport, who was bound over to assist in the prosecution of four laborers named Reynolds who committed assault and battery on Tibbals' person while he went about his duties. ${ }^{254}$

Yet avoiding the dangers of office could also be problematic for those expected to provide the manpower and muscle that underpinned local justice. In 1653, two Essex JPs delivered a warrant to Constable Stephen Nightingale of Newport for the "searching and

${ }^{252}$ J. S. Cockburn, A History of English Assizes, 1558-1714 (Cambridge: University Press, 1972), 1-48.

${ }^{253}$ Herrup, 3-6, 200-204; Fletcher and Stevenson, 16, 38.

${ }^{254}$ ERO, Q/SR 362/92. 
apprehending" of one Robert Pervivall "for great offences, mi[s]demeanors and traitorous speeches." Perhaps thinking that discretion was the greater part of valor, Nightingale neglected the warrant and was indicted for his dereliction. ${ }^{255}$ There is of course limited information, but the frequent indictments, presentments, and recognizances of constables or those who took issue with them indicate not only the nature of the constable's position, as one who served on the front lines of the battle against bad behavior, but it also shows the difficulties which those tasked with maintaining order could face. Also, Nightingale's case reveals the force behind the enforcement of order: the justices of the peace. Constables often may not have had much concern with their duties, but a concerted effort by JPs could cause the arrest rate to increase or decrease depending on how closely the justices held their assistants to account. ${ }^{256}$

So, though we cannot ascertain an absolute indication of the level of crime or disorder in the society, it is possible to see from the court records the manner in which crime was dealt with by the judges and potentially punished, and the priorities of those who were tasked with maintaining order. How JPs and local officers reacted to various matters brought to them, and the punishments proffered, indicates whether they saw a particular matter as relatively superfluous—not much of a threat—or as of particular concern. The perspective they provide is often more valuable than the very biased narrative or diary sources that survive. ${ }^{257}$

The matters justices confronted were centered on solving problems related to personal disputes, enforcing statutes, and punishing those who broke the rules. But what

\footnotetext{
${ }^{255}$ ERO, Q/SR 358/100.

${ }^{256}$ Wrightson, "Two Concepts of Order," 36-38.

${ }^{257}$ Elton, 1-6.
} 
underlay all the justices' efforts were ideas of morality. ${ }^{258}$ Making sure that orphaned children and wounded soldiers were cared for, rates equitably paid, responsibilities for bridges and roads honored, prisoners properly provided for and the sexually incontinent disciplined were all matters of right and wrong: charity, duty, and moral rectitude. The justices looked after the good of the community, and that good was ensured by their collective conscience. The work was not only about good order but it also concerned the maintenance and propagation of goodness itself. ${ }^{259}$

\section{The judicial benches of Essex}

The justices worked on the basis of general practices and consensual moral values as allowed and directed by the statutes of Parliament and the directives of Whitehall. But each locality had its peculiar history and set of problems with which its justices had to contend. The county of Essex, the subject of much of this study, was no exception. During the wars, Parliament was completely in control of the county. However, in 1648 there was a violent reaction to political events in central government.

As Puritan a county as Essex was there was enough opposition to Independent rule to raise the standard for the king even after the First Civil War had been won. The greatest battle in the nationwide revolt considered to be the Second Civil War was in Colchester, one of the largest towns in England and the de facto capital of the county (although meetings of countywide government were held in Chelmsford due to its more central location). Much of the town was destroyed in a two month siege when promonarchy, anti-government forces were besieged there. After the New Model Army had

\footnotetext{
${ }^{258}$ Herrup, 5.

${ }^{259}$ Fletcher, Reform, 262-269.
} 
won its victory, Lord Fairfax, commanding the besieging Parliamentary forces, had the two main "rebel" leaders shot on the spot, behavior fairly rare during the First Civil War. By 1648, however, Fairfax's men had already won for Parliament once, and after having lost many more lives in the fruitless rising and devastating siege, the leaders of the army and government had lost their patience with games of war and rebellion. The damage of the siege and punitive executions put an end to risings in the town, but the rebellion had shown that even in one of the most consistently godly counties there was still considerable potential for rebellion, dissent, and disobedience. ${ }^{260}$

Despite the years that had passed and the apparent calm, the 1648 experience of Essex in the Civil Wars had a strong influence on how Cromwell's government viewed the county and matters within it. Having been once bitten by the rebellion of 1648 , the government was more than twice shy about letting political matters get to the point of engendering another outbreak of mass violence. So when enemies threatened to take control of the Colchester Town Council at the expense of the pro-government faction, the Council of State intervened. During 1655, the results of the town council election were contested. The local "well-affected" petitioned the Protector to assist in seating them in their offices. After a spate of petitions, letters, and investigations, the council confirmed the previous, pro-government officeholders in their posts regardless of any objections from moderate opponents. ${ }^{261}$ It is certainly reasonable to suspect that the opponents of

\footnotetext{
${ }^{260}$ Woolrych, England in Revolution, 413-419.

${ }^{261}$ J. H. Round, "Colchester During the Commonwealth,". English Historical Review 15 (October 1900): 641-664; CSPD, 8:202-204, 378.
} 
the government had actually been victorious in the election. ${ }^{262}$ The difficulty was that in such cases the government was constrained either to side with supporters by overriding opponents or to risk the damage that opponents in power might do. Not surprisingly, Whitehall opted for peaceful exclusions rather than possible disintegration into chaos, destruction, and the further shedding of the "blood of saints." These exclusions created more resistance, which in turn led to more exclusions, arrests for sedition, and other reactions, and so on. Several factors fed this worsening loop, but the most important was the unreasonable hope of being able to "square the circle" of having a representative government which was not supported by the majority of the political nation. ${ }^{263}$ Cromwell wanted traditional parliamentary government to work and tried repeatedly, but he would not again risk the country falling into further Civil War.

During this period there seemed to be endless energy for squabbling and precious little for cooperation. In this time of fervent disagreement over what constituted good government, right religion, and the appropriate measures of each, the "good old cause"republicanism — and the various splinters of the godly cause could only function together if both made sacrifices in the name of pragmatic considerations. Unfortunately, most of those who sought to influence or participate in government were unable to see the benefits of compromise, and none had a majority because the allegiances and ideals of the many splintered factions were both too fervently felt to allow compromise. ${ }^{264}$ The

\footnotetext{
${ }^{262}$ In disputes such as this in which factions are concerned primarily with presenting favorable information about returns to support their claims to power it is very difficult to consider the accounts and claims of either side as particularly reliable.

${ }^{263}$ Christopher Hill, Religion and politics in 17th century England, vol. 2 of The Collected Essays of Christopher Hill, (Amherst, MA: University of Massachusetts Press, 1985), 85; Little and Smith, 127.

${ }^{264}$ Little and Smith, 127; Smith, Cromwell and the Interregnum, 2-10.
} 
fact that the Colchester Independents relied on help from central government to resolve their differences indicates that the party well-affected to the government did not have the political support necessary to resolve the differences themselves. But the government still had significant and important support in the county. After Penruddock's rising, the well-affected rose enthusiastically in response to the Royalist threat. "Truly there hath bin such forwardness....and noe less ready compliance in the country also, as could not have bin expected...and such a damp seemes to be upon the spirits of malignants." ${ }^{265}$ The county was still politically divided, and it was against a backdrop of these issues that the justices of the peace and major-generals would work to improve order and security in the counties.

The political allegiances of those who sat in the town councils were of great importance to Whitehall, and so were those of the men who sat on the benches. Throughout the late Elizabethan and early Stuart periods, central government had exerted significant effort to control the membership of the benches for political and practical reasons. The crown wanted to ensure quality: a combination of legal competency and status; in political terms, the government wanted to ensure loyalty. The Council of State would continue to pursue these aims during the Interregnum, though during those fractious times the government's priorities would certainly tilt toward favoring loyalty over stature. ${ }^{266}$ Being "well-affected" would trump being well-heeled of effective,

${ }^{265}$ TSP, 3:253.

${ }^{266}$ Hirst, England in Conflict, 282. 
though the selection of those who sat on the benches would typically be a combination of both. $^{267}$

Four times per year, the crown or central government vested JPs with their authority via the "commissions of the peace," as they had done and would do for centuries before and after the Interregnum. Each county's commission of the peace listed the justices who served in that county. During the Commonwealth-as beforethe commissions of the peace for Essex generally contained the names of some of the most powerful figures in the realm, such as Nathaniel Fiennes, Keeper of the Seals; Robert Rich, Earl of Warwick, the most powerful and "well-affected" lord in the county; John Thurloe, Secretary of State; and in the period of 1651-1653 even Oliver Cromwell's name appeared on the list before he was named Protector (in whose name the commissions were issued). ${ }^{268}$ But their inclusions were mere formalities; none of these men ever sat at the quarter sessions, or the assizes for that matter. ${ }^{269}$ Instead, the quarter sessions were completely under the control of local JPs, whose names also appeared on the commissions of the peace. Order of recorded names is an uncertain determinant of status, but frequent MPs, including Sir Richard Everard (who was also custos rotoloum, or keeper of the rolls, at the sessions), Sir Thomas Honywood, Sir Henry Mildmay of Graces, and Sir Thomas Bowes, were present and listed before the other shire JPs in the attendance list. These men were an important link between central government and the localities, and when present their authority would have been felt. Following their names on the commissions of the peace, and the attendance lists of the sessions, were JPs

\footnotetext{
${ }^{267}$ Hirst, England in Conflict, 282.

${ }^{268}$ Assizes files, 35/92-100.

${ }^{269}$ Fletcher, Reform, 5.
} 
usually of non-Parliamentary status (though some were knights and most or all were designated as "Esquire"). Some justices attended and served with great regularity, like Anthony Luther from the Ongar Hundred, who missed only one session in the period 1654-1658 and sat a total of thirty-one times over the period of the Interregnum, according to the order book, from 1652-1661. Joachim Matthews of Maldon sat twentyone times before his death in 1658 and Dudley Templer contributed a score of appearances between the battle of Worcester and the Restoration, but others sat much less frequently, such as Christopher Muschampe (10), Tristam Conyers (9), and Richard Cutts $(12)^{270}$

Prior to the Civil Wars, the crown worked to edit the membership of the commissions of the peace so that opponents, perhaps better described as those critical of crown policy, were excluded or marginalized. But because the benches were the power centers in the localities, the greatest landowners and gentry-whatever their sympathies - desired to take their rightful place on the benches. Thus through patronage alliances with important figures at court, they usually managed to find their way back onto the "parliaments of the shires" because of the social importance of the courts. ${ }^{271}$ But the Civil War period in Essex — and generally throughout the country—was an exception to that rule. The pre-1640 bench had significant differences from the post-war bench. There were further changes after Pride's Purge, ${ }^{272}$ which occurred not long after the

\footnotetext{
${ }^{270}$ QSOB, xxxiii-xli.

${ }^{271}$ Fletcher, Reform, 12-19, 98.

272 Pride's Purge was the removal of anti-army MPs from the Long Parliament. What remained were those of the pro-army Independent, or more radical faction, who would subsequently be known as the Rump Parliament, which was responsible for executing the king, and was dissolved by Cromwell in 1653. Worden, ECW, 98-125.
} 
Colchester rebellion, when Presbyterians were removed from Parliament. Once those who had sided with the Colchester rebels had been removed, membership on the Essex bench was characterized by a significant degree of continuity through the Interregnum. This coincided with a countrywide narrowing of bench membership as power was consolidated into fewer hands - and more radical ones at that. ${ }^{273}$ The bench in 1652 was populated by more or less the same core cast of JPs as during the time of the majorgenerals, and the core of justices by man or parentage went back into the pre-Civil War period, including several who had been excluded temporarily from the bench for resisting Charles I's extra-Parliamentary "ship money” levy. ${ }^{274}$

The most dramatic change in bench membership in Essex would come after the Restoration, when almost all of those who appeared in the 1650s were purged, though most were not prosecuted for their support of the previous government. This was not the case in all counties, which is an indication of the particularly godly nature of the benches in Essex. ${ }^{275}$ Restoration changes in county administration were certainly dramatic and important in their own right, but for the purposes of this study the impact of the Restoration serves mainly to underscore the pro-Cromwell leanings of the Essex bench during the Interregnum. A few long-servers remained under Charles II, including Sir Richard Everard, Anthony Luther, Gobert Barringon, and John Atwood: men of experience either powerful enough or with political leanings inoffensive enough not to warrant exclusion. But the majority of JPs were removed. ${ }^{276}$ In previous periods, the

\footnotetext{
${ }^{273}$ Fletcher, Reform, 15-19; QSOB, xxxi-xli.

${ }^{274}$ Quintrell, 43, 319-357; QSOB, xxxi-xli, 1, 12, 82, 92.

${ }^{275}$ Fletcher, Reform, 18-19.

${ }^{276}$ QSOB, 201, 192. Essex Quarter Sessions Rolls, ERO, Q/SR 298-395.
} 
office of JP had been somewhat of a revolving door-those who got out could generally find their way back in. But from 1640 to 1660 , the gentry community had fractured in ways it previously had not, and this impacted who would be on the benches and who would be left without power or a voice in their local community.

One interesting point regarding the major-generals initiative and the JPs was that several of the Essex justices took new jobs during this time: they joined the majorgeneral's staff and became commissioners "for securing the peace of the commonwealth." ${ }^{277}$ Thus, there would hardly be a significant degree of enmity between the justices and the commissioners, even though a few of the commissioners were not also JPs. Double membership would indicate that some degree of continuity between the work of the JPs before and after the forming of the major-generals' commissions would be expected, and it would also mean that the JPs probably would not change their focus because of the influence of outsiders, or men unfamiliar with the bench. Instead, alterations to judicial practice would be due to a change in focus based on the new directives from Whitehall. Thus, any opposition to the major-generals would have had little to do with resentment toward outsiders; instead, it would have been because JPs were going about their work differently, or even doing some things that were completely new. Thus in the period beginning in late 1655, the "commissions of the peace" (which gave authority to JPs) and the "commissions for securing the peace of the Commonwealth" (which authorized the major-generals and commissioners) were similar. If Essex is any indication of what went on the rest of the nation, "swordsman" simply

${ }^{277}$ Durston, 60-79; TSP, 4:317. 
meant "JP"; and if major-general meant "bashaw," then JP did as well. ${ }^{278}$ However, these JPs were mostly the JPs of the previous few years, not the JPs who had been in power in the 1640 s or under King Charles I, and important county families who had previously been represented on the benches were excluded. The JPs and commissioners were not from outside Essex, but some of them were definitely from outside the traditional magnate circles. ${ }^{279}$

Yet in the eyes of Major-general Hezekiah Haynes the local sessions and assizes were hardly harmonious gatherings. After Penruddock's rising, Haynes wrote to Thurloe about his great concerns for security and the possibility of rebellion which he feared might grow out of the upcoming assizes. Haynes had not heard of any plots, but he feared rebellion because those ill-affected were "appointing so many malignants, and such as have engaged against us of the grand jury for this countye." ${ }^{280}$ His fears were grounded in experience, and he compared the rebellious mood following the 1655 rising to atmosphere prior to the June 1648 outbreak of the Second Civil War. "The like hath not bin since forty eight, when the rysing was in the country; and their busyness past and formed at the assizes." ${ }^{281}$ At the Essex assizes of 1648, the Presbyterian faction had published a petition addressed to the House of Commons requesting on behalf of all "loyall and true-hearted knights, esquires, gentlemen, and free-holders within the County

\footnotetext{
${ }^{278}$ There is limited information regarding the identity of commissioners in the country, but the inclusion of JPs on the commissions was not infrequent-though generally not as frequent as seen in Essex. Durston, 69-71.

${ }^{279}$ Fletcher, Reform, 16-17.

${ }^{280}$ TSP, 3:284-5; Haynes was only a major in March of 1655, though he is identified by his future rank here for clarity.

${ }^{281}$ TSP, 3:284-5.
} 
of Essex" that Parliament come to a settlement with the king. ${ }^{282}$ Royalist revolts broke out in London in April and Colchester rose for the king in June.

Afterward, the membership of the Essex benches changed significantly, undoubtedly for security reasons. With the precursors to the 1648 rising in mind, Haynes resolved in March of 1655 to send troops to "attend the judges in the tyme of their sitting, and shall, God willing, be upon the place myself to observe them."283 JPs were not named as enemies, and one of them, Dudley Templer, was a major in Haynes' regiment. $^{284}$ But those present at the judicial sessions/parliaments of the shires could still present a threat. The Essex bench during Haynes' time was actually reasonably wellaffected to the government, but Haynes obviously feared that was not enough. The assizes and quarter sessions consisted of jurors and head constables as well as JPs, and the grand juries were usually comprised of lower gentry or yeomen. Apparently Haynes felt that those groups had contributed to the start of the Second Civil War and so controlling bench membership was not the only necessary step to insuring the safety of the county. Haynes surveillance of the bench does not indicate a tyrannical impulse to bully them, though. After considering the previous anti-government activity at the assizes which led to Colchester, which Haynes called a “desperate malignant towne,"285 being half-razed in 1648, Essex's commissioners' efforts to control bench membership and keep an eye on the sessions seems like nothing but a prudent concern for the safety of

\footnotetext{
${ }^{282}$ The Petition and Desires of all the loyall and true-hearted...of the County of Essex (London, 1648), 1. ${ }^{283}$ TSP, 3:285.

${ }^{284}$ Haynes said that Templer "merits for the steadfastness of his affection and resolution in these wavering tymes. TSP, 3:285.

${ }^{285}$ TSP, 3:247.
} 
the Commonwealth. Rather than "godly" reformation or tyranny, they simply aimed to avoid the outbreak of a third civil war.

Based on the exclusion of the "ill-affected" JPs before the Interregnum — and the inclusion of JPs on the major-general's "staff"- some of the membership of the Essex bench before the arrival of the major-generals was already well-affected to the government. But what were the priorities of the county bench during the period, and how much of an impact would the major-generals and commissioners have on those priorities and the work that JPs did? Looking at the court records can help answer these questions, for they reflect any changing focus of judicial proceedings in the county. Also, beyond reflecting the aims and influences of JPs and major-generals, the records do reveal a significant amount about the life of the common people. JPs' attitudes are reflected in the records, which generally reveal what the justices considered important—or important to eliminate - and the view of the world of the lower and middling sort is somewhat skewed since it is viewed through the gentry's eyes. But the common people do play the starring role in the court records, and examining them opens a fascinating window into the world of the common people of the seventeenth century, at least in Essex.

Before commencing an examination of the court records, it is worth repeating the limitations and strengths of those records. Because of limited record survival and other factors, the analysis will not approach any sort of statistical certainty, though some basic statistical methods will be used. Also, the work of other scholars who have done research—particularly statistical research—on crime and order will be employed as well. Mostly, however, the examination will provide indications of what occurred by looking 
closely at individual cases, which give a good indication of what the justices and people of the community thought needed to be addressed and what their priorities were in addressing those problems. Also, in addition to revealing what justices thought was worth attending to, the records show how JPs thought those matters should be dealt with: harshly, leniently, or using fines, gaol, or simply (it would seem in some cases) a good scolding. The justices had opinions about what was needed to keep order in their communities, and they acted accordingly.

Part of this analysis will be concerned with noting basic case levels: for instance, if sexual congress out of wedlock was not important to the justices it probably would not have been much addressed by the courts. Also, some longitudinal analysis will be useful, since increases in reports of a type of offence or increases in punishments could signal a change in emphasis. Noting this sort of change regarding the major-generals' initiative will be particularly important. It will also be important to focus on the period when Hezekiah Haynes as a major-general and the Essex commissioners were active (from November 1655 to probably February of 1657). But it is also essential to look at the years before and after to get an idea of the sorts of disorders with which JPs were generally concerned. For example, if dramatic changes occurred during the majorgenerals' tenure, those changes would indicate the influence of the major-generals. If there is emphasis on the suppression of specific types of disorder during the period, those offences would occur more frequently, though it would be important to consider the possibility of a rise in that type of trespass or crime. It is also worth noting the sorts of punishments meted out at the assizes and the quarter sessions: if the penalties were 
greater once the major-generals arrived, it could demonstrate a greater focus on harsh punishments in place of the negotiative clemency the JPs throughout the seventeenth century otherwise seem to have preferred. Also, a closer adherence to Interregnum ordinances or attention to matters listed in the orders to the major-generals might have indicated an increase in the influence of the central government.

However the sources are analyzed, it is important to reiterate the number of loosely connected parts in the judicial and administrative system, and the degree of complexity that such a human system represents. As in any area of human endeavor, the factors were many and unassailable determinations of causality are impossible. Yet as the work of many scholars has shown, evaluating such material can give strong and important indications of what was happening in society and, to some extent, why. It is this sort of analysis that this thesis is undertaking in regard to the work of the JPs and the major-generals in Interregnum Essex.

Some scholars have asserted that the major-generals were deeply committed to effecting a godly reformation on the localities, but one of the contentions of this study is that godliness was no more an aim than that of increasing order and security. In many cases it is actually a rather difficult matter to find a delineation between the two: social order and morality were closely related in the early modern mind. ${ }^{286}$ Even the vigorous pursuit of administrative enforcement was perhaps prompted "partly by moral panic.",287 One example of the link between disorder and religion regards the fairly well-known fear of disorder brought by Quakers in the 1650s. The Quakers were a religious sect, but in

\footnotetext{
${ }^{286}$ In the early-modern mind there was an inescapable connection between ideas of sin and both social order offenses and crimes that came before the justices. Herrup, 6 .

${ }^{287}$ Fletcher and Stevenson, 36.
} 
the 1650s what set them apart from Baptists, Presbyterians, etc. and brought them attention was not their doctrine but their penchant for defiance and disruption. Also, matters regarding alehouses during the period show a preoccupation with the danger these establishments presented. But whether attention to alehouse regulation reflected concerns about the moral quality of the community or the safety of the state requires examination. Offences against order such as scandalous behavior, drunkenness, disorderly alehouses, vagabondage, cottaging, speaking against ministers and the government, breaking — the opposite of keeping — the peace, recusancy, and so on also have a more or less direct aspect of morality about them. So it will be important to analyze the other information given in the various presentments, indictments, recognizances, and court orders to see to what extent morality or order were mentioned as reasons for various judgments and actions. It is also worth noting that nearly all government proclamations and orders during the period claimed religious purpose or divine approbation of their policies and orders. So the appearance of religious language cannot be taken as a definite determination of religious motivation. Some scholars have argued the religious motivations for the major-generals' social order reforms. But one (John Morrill, a scholar very familiar with the Civil Wars and their religious causes), has also noted that social defiance was characteristic of the period. ${ }^{288}$

\section{Order and morals: sexual transgressions}

Puritans' loathing of sexual transgressions is well-known, and punishing such violations went hand in hand with enforcing "godly discipline." Therefore, matters

\footnotetext{
${ }^{288}$ John Morrill cited in Fletcher, "Local Officeholding," 113. Morrill generally emphasizes the religious issues during the period, though he has also examined and noted the scope of disorder.
} 
touching "incontinency" might reveal the extent to which a puritanical mindset motivated those who sat on the bench. Previously under Catholicism or less radical Protestantism, dalliance had often been dealt with rather leniently or largely ignored—at least according to Puritans. But under the rule of the godly, it was intended that such license should not prevail. ${ }^{289}$ Analyzing court business dealing with sexual offenses can indicate Essex Interregnum JPs' attitudes toward the issue, and since it was an important issue for the godly government, it can indicate how closely they pursued Puritan moral ideals in their judicial practice. One of the earlier acts of the Rump Parliament in the Interregnum period was the Act for suppressing the detestable Sins of Incest, Adultery, and Fornication of 1650, which made certain types of adultery and incest felonies punishable by death. ${ }^{290}$ The harshest penalty was almost never applied anywhere in the country, though it perhaps found its effectiveness as a deterrent resulting in a significant reduction in prosecutions for adultery. ${ }^{291}$ It is difficult to say, however, whether the drop in prosecutions was a result of ignoring the crime or dealing with it differently, or because the populace stopped its illicit copulations. People being what they are, it is hard to imagine that alterations in actual sexual behavior were the reason for the change. In any case, even if we are unable to determine changes in actual levels of adultery, we can at least note whether many cases appeared in the court records, how they compared with other matters brought before the justices and how they were generally resolve. The result

\footnotetext{
${ }^{289}$ Margaret Spufford, "Puritanism and Social Control?" in Fletcher and Stevenson, 47-57; Ingram, 1-24.

${ }^{290} A$ and $O, 2: 387-9$; ERO, Q/SR 355/32, 100, 101, 105, 356/19.

${ }^{291}$ Keith Thomas "The Puritans and adultery: the Act of 1650 reconsidered" in Christopher Hill, D. H. Pennington, and Keith Thomas, eds, Puritans and Revolutionaries: Essays in Seventeenth-Century History Presented to Christopher Hill (Oxford: Clarendon Press, 1978), 257-282.
} 
of this analysis can then indicate the priorities of the justices on the Essex bench regarding these "detestable" sins.

Sexual matters were definitely brought before the courts-and a fair number of them. They fell into three categories. First were those of incest, which were exceptionally rare and usually ended up at the assizes due to the severity of punishment for that offense. Then there was adultery, also called fornication or incontinency, which during the Interregnum was treated as a criminal matter. Prior to the Civil Wars it had generally been a problem dealt with by the church courts. The third matter was illegitimate birth, or bastardy. In the few cases in which the mother was accused of infanticide the matter would be bound over to the assizes. But most cases of bastardy, like those of fornication, were dealt with at the quarter or petty sessions.

One might expect a godly bench to penalize to the utmost extent of the law such sinful behavior as sexual offenses. Yet when such matters were brought before them, justices were actually reluctant to penalize too harshly those accused of prurience under the Puritan regime. Notable was the case of Elizabeth Hills of Little Wakeringe. In January 1653 , the sessions judges directed an investigation into the whereabouts of Thomas Rutland, who had several times been bound over by the court for various minor matters and was the "reputed father of the Base Child" born to Elizabeth Hills. ${ }^{292}$ The justices directed that the two local JPs of the hundred "make such order therein for findinge out the reputed father." The father had not been either located or proved by the next sessions, and Hills was sentenced to one year of imprisonment. Significantly, she was

${ }^{292} Q S O B, 22$. 
convicted for havinge a Bastard Child kept at [th]e charge of [th]e said $\mathrm{p}$ [ar]ish, and the Church wardens \& Overse[er]s for the poore of that $\mathrm{p}[\mathrm{ar}] \mathrm{ish}$ are hereby required to $\mathrm{p}$ [ro]vide for the said Child, left to the p[ar]ish charge as aforesaid. ${ }^{293}$

As written in the order book, the penalty indicates that her trespass was at least as much for constituting a burden on the parish and the community as for moral turpitude. The 1650 statute mandated

every such man so offending, and confessing the same, or being thereof convicted by verdict upon Indictment or Presentment...shall for every such offence be committed to the common Gaol, without Bail or Mainprize, there to continue for the space of three Moneths. ${ }^{294}$

Instead, the justices applied the Jacobean Act for the execution of divers Laws and Statutes heretofore made against Rogues, Vagabonds and Sturdye Beggars and other lewd and idle persons (1610). That statute read, "every lewd woman which shall have any bastard which may be chargeable to the parish, the justices of the peace shall commit such woman to the house of correction, to be punished and set on work, during the term of one whole year."295

Consider also the case in Radwinter in northeast Essex where two local men presented Nicholas Taylor for begetting a child by Anne Taylor, a single woman. There is no indication the two lovers were related, and the order book does not mention incest. Rather than sentencing the man as the act demanded, the concern of the justices in his case was that he be made to support the "[b]ase malechild" so that the parish poor rate payers would not be further burdened. The adulterous father was directed to "mainetyne, keep and p[ro]vide" for him or to pay 18 pence per week to the "Churchwardens and

\footnotetext{
${ }^{293}$ QSOB, 26-7.

${ }^{294} A$ and $O, 387-9$.

2957 James I cap. 4
} 
Oversee[r]s for the poore for upkeep of the child, in addition to giving "good security by Bond of 40 [pounds]." The mother's fate was another matter. She was given a year of imprisonment for her iniquitous deed. Nicholas did go to jail until "he should find sufficient sureties to perform the justices' order." But his stay was not long, for two days after the gaol calendar listed him, his gaoler yeoman Nicholas Roberts was charged with allowing the male Taylor's escape. ${ }^{296}$ One could find oneself indicted, though a jury acquitted this inattentive gaoler at the October sessions. In any case, no one was hanged for incontinency, though Anne (also listed as Jane in the sessions rolls) suffered the worse penalty, while her child's father, even if he had not escaped, seems not to have warranted imprisonment in the eyes of the justices. ${ }^{297}$

Although in Hills' case the man was not to be found and could not thus be charged under the provisions for rogues which was applicable because he had left the child in the care of the parish, in the case of the Taylors the man was required only to give surety for his behavior rather than receive the sentence under the act of 1650 . This indicates an emphasis on practical solutions over moral correction, though the Interregnum law provides the significantly harsher penalty of three years in gaol and branding for subsequent incidences of fornication. It is also worthy of note that the woman was punished for the crime while the man went free. ${ }^{298}$

\footnotetext{
${ }^{296}$ Roberts' travails in this case point to the risks involved in being a correctional superintendant. ${ }^{297}$ QSOB, 20.

298 Alan Macfarlane, "Illegitimacy and illegitimates in English history," in Peter Laslett, Karla Oosterveen, and Richard Michael Smith in Bastardy and Its Comparative History: Studies in the History of Illegitimacy and Marital Nonconformism in Britain, France, Germany, Sweden, North America, Jamaica, and Japan (Cambridge, MA: Harvard University Press, 1980), 73-4. It is also worth noting that the act of 1650 prescribed death as the penalty for adulterous wives but not for husbands - a clear double standard.
} 
The use of the 1610 law also allowed the justices to deal with another matter which was of constant concern to them: parish poor rates. Dealing with the ratespunishing non-payment or non-collection, settling persons on parishes, or dealing with requests from overburdened parishes for reductions - made up about a quarter of the county sessions order book's entries. The number of complaints about paying high rates indicated the widespread nature of the problem, and it seems reasonable that the justices, who were also rate payers, would have made every effort to reduce the burden on parishioners regardless of any concern for punishing the "detestable" cause of the illegitimate issue itself. ${ }^{299}$ Though the lost process rolls for the period might have contained more entries regarding charges for incontinency (with only a few bound over to the assizes or presented by the grand juries), there were actually few indictments for incontinency when an illegitimate child was not involved.

One of the rare cases in the county order book involving adultery regards the inaptly named Justice Symonds. It names Richard Freeman as the partner in sin of this lonely widow, he having had "carnall knowledge of her body." The two had previously been indicted for their activities and bound to good behavior. But in the later offense the court took an unusual interest in the case, and the justices deemed that "the matter appearing very fowle, This Court Doth thinke fitt...That the next Justice of the Peace Doe send for the said Justice Symondes" to answer for her actions. Yet despite the "fowle" nature of the violation, the justices apparently saw no need to try and imprison her for her initial act, as the act of 1650 would dictate, but rather again only to "bind her to her good

\footnotetext{
${ }^{299}$ Macfarlane in Laslett, 73-4.
} 
behavior." ${ }^{300}$ Even in this case the goal of assuring good behavior and order in the community was preferred to the gaol time prescribed by statute, though lost records or "lost" persons could account for the lack of further mention. ${ }^{301}$ Ms. Hills on the other hand, who had burdened the community with a child to support, was listed in the house of correction during the subsequent sessions, though she is not mentioned thereafter. Even in this particularly godly time, costing ones fellow parishioners warranted harsher treatment than the sinful act itself. ${ }^{302}$ Sexual license may have ruptured the moral fabric of the community, but JPs knew that unaccounted children could break a parish's back financially as well.

As time went on, though, the penalty of the 1650 statue seems to have been applied with more regularity. The rolls recount the case of Mary Franck, a widow of Goldhanger who became "carnally known” by a Mr. Tebell of Tolleshunt. Mary was given three months upon her acknowledgement of guilt. ${ }^{303}$ In April of 1655, John Carter and Mary Martyn were "indicted for fornication and found guilty, to remain in Goal three months and then to find sureties for good behaviour for twelve months." ${ }^{304}$ Curiously, justices began at times to include reference to the 1650 statute on which they based their punishment in the cases of adultery, as "according to the late Act against the detestable sin of fornication" was included in the order for punishment. ${ }^{305}$ Yet the same sessions where Franck and Martyn were recorded to have been assigned to imprisonment in the

\footnotetext{
${ }^{300}$ QSOB, 138. The quarter sessions roll indicates that previously on August 28, 1658 she had been bound to good behavior. This may indicate previous knowledge by the justices, which might indicate an even more reduced inclination to punish such deeds with imprisonment. ERO, Q/SR 377/15, 50, 52.

301 "Lost" here referring to those who were bound to good behavior and then disappeared.

${ }^{302}$ ERO, Q/SR 357/92.

${ }^{303}$ ERO, Q/SR 364/13.

${ }^{304}$ ERO, Q/SR 364/104.

${ }^{305}$ ERO, Q/SR 371/38.
} 
notoriously damp Colchester Castle, Thomas Wright, tailor, and Joan Raworth were required to suffer no more punishment for their "female bastard child" and the "divers times" Wright "had knowledge of her" than to pay a combined 2 shillings 18 pence per week to the parish for the child's maintenance until she reached eight years of age. However, considering that the parish payment was unusually high, it is possible that the guilty parties may have avoided the penalty for their "detestable act" because they were kind enough not to burden the parish with paying for a child—and perhaps contributed a bit more than required for this purpose. ${ }^{306}$

The varied punishments involved in these cases reflect two elements of the local, early-modern justice system. Whatever the law stated, justices generally had a good deal of discretion in how to deal with offenders. Because of the limited amount of information included with punishments, it is difficult to know what inclined justices to rule one way or another. Yet they most certainly did take advantage of the discretion available to them, and in the cases of adultery there seems to have been a preference for paying the parish over making the guilty pay for their sins. Their way of dealing with sexual matters also demonstrates another traditional goal of justices, the emphasis on practical outcomes over punishments. ${ }^{307}$ The court orders show favoritism toward those who could help keep the poor rates down, often making punishment of moral wrongs a subordinate to the practical matter of material upkeep.

\section{Alehouses: source of sin or hotbed of sedition}

\footnotetext{
${ }^{306}$ ERO, Q/SR 364/99.

${ }^{307}$ Herrup, 42-43.
} 
To the justices—and everyone in the period—morality in and of itself certainly had intrinsic value. But there was the understanding within the community that many offences were not only "fowle," as in the case of widow Symonds the adulterer, but a threat to order generally. Evil had many sources, but for many Puritans ale and the establishments providing it to the pubic were a primary cause of sinfulness. ${ }^{308}$ Regulations in the Essex order books reflect this conflation of disorder-and even rebellion - with drinking establishments. The suppression of alehouses in Maldon was one of the most common matters brought before the court there during the period for which records are available, 1654-1658. A petty session of the town which began on April 10, 1655 in Maldon's Mootehall indicates the attention that the local magistrates paid to the problems of ale and order concerning three ale houses of the town: the Flowerde Lane, the Redd Lyon, and the Chequer. The keeper of each was "licensed by the Bailiffs and Justices of the Burrough to keep a com[m]on alehouse."

Yet the license had conditions. The keepers John Barnes, Francis Slane, and Thomas Steevens were required to give a surety for good behavior: ten pounds for each owner and five pounds for two other men who were either employees or simply friends willing to vouch for the innkeeper's moral character. In addition to the surety, the order book describes the other stipulations governing the owners and alehouse keepers which were licensed for a period of one year ending at the Easter sessions of 1655. They were not to

permitt or suffer any playing at cards dicetables bowles or any other [?]ful games in the said outhouses backside and shall [not] harber in the same or

${ }^{308}$ Sharpe, 49. 
in his Barnes stables any other places any rogues vagabonds sturdy beggars masterless men or any of the suspected $\mathrm{p}[\mathrm{er}]$ sons whatsoev[er] ${ }^{309}$

Clearly, the town council was concerned with the connection between those who drank and those who presented a danger to the community. The language in the order is a semistandardized composite of a variety of acts regarding alehouses and disorderly persons from previous reigns, including the 1572 Act for the Punishment of Vagabondes and for Relief of the Poor and Impotent, and the Rump Parliament's May 1649 Act for the Relief and Imployment of the Poor, and the Punishment of Vagrants. ${ }^{310}$ The Maldon justices also directed the licensed alehouse keepers not to "sell or uffer any beere ale or any other victuall up[on] the Saboath day" or to suffer any to "remaine tipling or drinking in the said house contrary to the lawes." In addition, standard measures for bread and ale were to be used, and "from tyme to tyme [the keepers were required to] entertain and lodg such strangers as shall by the said Bailiffs, Justices or their officers be sent or brought unto him.... without denial or contradic[t]ion. ${ }^{\text {311 }}$ Not only were the keepers required to adhere to the laws demanding good order, but they were also to provide accommodation for those who had business with the town's magistrates. The price of a license thus covered not only good order but accommodation at the behest of the town's officers. Providing accommodation for outsiders was an important social role of the establishments—another example of the regulation of alehouses for practical rather than moral purposes.

Often petty session's rolls from the period are difficult to come by. But the Maldon order book is similar to petty sessions because it lists the results of monthly

\footnotetext{
${ }^{309}$ Essex Record Office, Maldon Sessions Book, 1631-1664 [hereafter Maldon SB] 201. D/B 3/1/20.

3103 Charles I, cap. 4; 14 Elizabeth I, cap. 5; 7 James I, cap. 10;1 James I, cap. 9; 4 James I, cap. 5, 39 Elizabeth I, cap. 4.

${ }^{311}$ Maldon SB, 201.
} 
judicial hearings. It also reveals the sort of business that burgesses and justices dealt with in small towns. The most frequent regards those admitted to the "rights and liberties" of the town, meaning the granting of status as freemen, through either inheritance or paid entry for between twenty and forty shillings. That sort of business resembles closely what is to be found in the county quarter sessions order book—activity related more to administration than justice. The Maldon book also includes such matters as each year's orders to audit the town's accounts, the names of the magistrates and officers, and other basic administrative details. In terms of punitive matters, the Maldon order book resembles in many ways the presentments brought to the full county sessions which were briefly recorded in the court sessions rolls. Individual indictments, recognizances for good behavior, and certain types of fines comprise significant portions of the work. In effect, the sessions of Maldon are somewhere between those of the full county quarter sessions at Chelmsford and the petty sessions held locally all over the county.

Significant felonies and serious misdemeanors were unlikely to have been dealt with at the Maldon petty or quarter sessions and would have found their way to the county sessions, as in the case of yeoman Nicholas King "suspected, reputed and charged to be the father of a bastard child whereof Susan Osborne of Maldon singlewoman was delivered concerning the death of the child." ${ }^{312}$ Maldon laborer Nicholas Utcher's case was also too serious for the Maldon sessions and thus found its way to the assizes, where he was found guilty and branded for stealing two heifers worth forty shillings each. ${ }^{313}$ Also bound over to the assizes was, Susan Long, widow of Salcott, who was accused of

\footnotetext{
${ }^{312}$ ERO, Q/SR 367/65.

${ }^{313}$ Assize files, 35/100/2/19.
} 
exposing a child overnight, "itt being then extreame cold frosty weather...[she] did not give the child sufficient nourishment so that she died." ${ }^{\text {,14 }}$ But other less serious matters could be dealt with by the Maldon court. William Rombold came before the justices at the sessions of April $20^{\text {th }}, 1654$ and was put under a surety of twenty pounds for a matter "touching incontinency with one Frances Ashton or Ashdon of Maldon." He was said to have "byne incontinent with her and to have gotten her with child.",315

The county quarter sessions rolls which included presentments from the hundred where Maldon was located contain a steady stream of recognizances for bastardy, though usually no further information is given, and it seems that in most circumstances-as in the Maldon court—whatever measures justices took at the hundred level were allowed to stand at the quarter sessions. Ashton and Rombold might have been forced to pay a heavier penalty which was recorded elsewhere. But the Maldon book records no punishment beyond the recognizance. An advantage of action by smaller-scale localities, like Maldon, was that local magistrates could keep a close eye on those who were under bond. Rombald and the amount of his surety were listed at the rest of the year's quarter sessions, as were those of William Brokys of Maldon and Thomas Bell of Parleigh (just outside of Maldon but within the town's jurisdiction) who were also bound on good behavior for unspecified offences against good order. ${ }^{316}$

Before the major-generals arrived, ale and its sellers were a common focus of the Maldon magistrates' attention, as was the case elsewhere in Essex. Not only those licensed but those unlicensed came before the justices. The same petty sessions at which

\footnotetext{
${ }^{314}$ Assize files, 35/97/3.

${ }^{315}$ Maldon SB, 201.

${ }^{316}$ Maldon SB, 202-203, 205.
} 
Rombold appeared on April 10, 1654 record that Francis Tunbridge, a net maker, was presented for "taking upon him com[m]only to sell beere in his dwelling house...on his owne authority not being thereunto lawfully licensed." Under the Caroline law of 1628, he and Ann Person, "widdow of Maldon," were fined twenty shillings each, which according to the statute was "forfeited...for the poore of the said p[ar]ish."317 Though poore relief was not mentioned in the Maldon book, the overseers of the poor would have had the same concern with too-heavy rates had been expressed by the county justices, one of whom, Joachim Matthews, held the office of recorder of Maldon-or the local custos rotolorum — and was usually the borough's MP during the Interregnum. As in Maldon, throughout the county the wages of sin were also the wages of the poor-be they the bastard children of men like William Rombold or others who required the support of the parishioners. One recipient was the aged George Smyth, and the Maldon justices and council ordered that the "p[ar]ish of All Saints doe pay the rent of the house where George Smyth liveth for one year...in consideration of the age and poverty."318 However, compared to other matters - not including the admission to the rolls of free men in the town-regulating and punishing those who made drink their business was the most common matter in the Maldon book. The justices were certainly concerned with making sure that licensed houses behaved properly, and they also took action against those who sold without a license.

During the period, central government also turned its attention to alehouse regulation. Not long after the major-generals arrived there was a new national emphasis

\footnotetext{
${ }^{317}$ Maldon SB, 202.

${ }^{318}$ Maldon SB, 205.
} 
on the regulation of alehouses, significant enough that a complete copy of a directive appears in both the county court records and the Maldon order books, ${ }^{319}$ and a similar printed declaration which appears to be almost a direct copy of the Essex order book page appeared in Hertfordshire simultaneously. ${ }^{320}$ The regulations listed in the Herts order are very similar to those found previously in the licensing of the Redd Lyon and other alehouses in Maldon. It stipulated that the new set of "Particulers followeing bee recom[m]ened to the Justice of the Peace in their several Divisions." Keepers were required to give a surety, and have "Two Spare Bedds att the Least and Stable roome for Foure horses, And that every Alehousekeep[er] hae signe over his Door." All the licensees had to be in "throughfare Towns, or in such Townes as stand upon the Sea coasts or neere Navigable Rivers" such as Maldon and "not in blind Lanes or Corners out of Roades." Justices were to be required to keep an eye on the alehouse keepers at their monthly meetings and to ensure

vigourous execuc[i] on of the Lawes for the Suppressing of all unlicenced Alehouses, and in causeing Constables and other officers to bee dexterous in discharge of their dutyes for the discovering, presenting, convicc[i]on and punisment of all such Offenders.

Importantly, the primary stipulation was that

noe persons bee Lycenced but such as are well affected to the Government, of honest life and convsersac[i]on, and such as bring certificate of the same under the handes of the Minister of theparrish \& Three or more well affected persons of the Neighborhood. ${ }^{321}$

\footnotetext{
319 Maldon SB, 217.

${ }^{320}$ At the general Quarter-session of the publick Peace of the County of Hertford (Hertfordshire, 1655), 1, Thomason H1602B.

${ }^{321}$ QSOB 81-82; Malden SB, 216.
} 
As the instructions in the county sessions order book matched those in Maldon's, the text was clearly provided by a published directive, most likely from Whitehall. Significantly, the order emphasized the non-moral reasons for the suppression of alehouses. The declaration of the Hertfordshire sessions is even clearer than those of Essex regarding the security measures included, directing that alehouse keepers not only be of "honest life and conversation" but also "well-affected to the Present Government" and "persons who have not adhered to the late King and his Party."322 Such a stipulation would have allowed JPs or a well-affected innkeeper to keep an eye on who was coming and going in the towns, thus providing an additional organ of Thurloe's spy network. Drink may have been the source of all manner of "outrageous practices and wickedness" 323 and morally corrupting in its own right, but there was unquestionably a security motive in the declaration and orders. The stipulation regarding the physical location of alehouses is particularly telling of the government's intentions and concerns. Ale and lodging houses off the beaten track would have been perfect places for secret meetings, the storing or collecting of weapons or other supplies for rebels, way stations for those going from place to place fomenting rebellion, and particularly in the case of Maldon as a port town on the southeast coast, for royalist agents and spies having come in from across the English Channel. The maligned alehouse keeper was thus quite possibly a "malignant" alehouse keeper for Cromwellian Whitehall; he was more a threat as a Royalist than as a peddler of drink.

\footnotetext{
${ }^{322}$ County of Hertford, 1.

${ }^{323}$ Quoted in Peter Clark, "The Alehouse and the Alternative Society," in Pennington and Thomas, Puritans and Revolutionaries, 47.
} 
The overall picture that emerges for the period before the major-generals "came to town" is that the regulation of drinking establishments was a concern of both the justices and the central government. Justices had long experience in dealing with the matter and seem to have had a strong inclination to engage in careful licensing and the prosecution of those who served without a license. Indictments and orders, gaol records, recognizances, and particularly presentments show a definite inclination across the county of Essex to deal with ale selling as a source of disorder. From summer 1654 to April 1655 the records show at least a dozen instances of those in trouble with JPs for illegal selling or serving, and the summer 1654 quarter session records twenty-two presentiments for illegal serving (and one for tippling and another for "assize of ale," or violations regarding serving portions). Though Essex was a large county with limited record survival, this relatively large number of cases shows consistent attention to the matter.

During the presence of Major-general Haynes and his commissioners, there was a slight increase in hundred presentments for drink and alehouse offenses. For the sessions from summer 1655 to autumn 1658 there are usually no more than eight presentments per administrative hundred for any session. ${ }^{324}$ April 1656, with seventeen, and October 1656, with eighteen, are notable exceptions, and it is reasonable to consider this an indication of unusual pressure, to be generated by the major-generals. ${ }^{325}$ The April sessions for the year had the following entry in the gaol calendar: "Tho. Waylett,

${ }^{324}$ ERO, Q/SR 363-377. Hundreds, or sometimes rapes, were the basic administrative subdivisions of the East Anglian counties. Each had a head constable who was responsible to the justices for keeping order in his hundred.

${ }^{325} \mathrm{ERO}, \mathrm{Q} / \mathrm{SR} 368,370$. 
committed for an unlicensed alehouse, 27 March, by Major General Haynes and Mr Whatcombe." ${ }^{326}$ So Haynes at least, and not improbably his other commissioners, were at work on what has been called "godly reformation" during the time when the spike in presentments is seen. However, this is the only reference in the gaol calendars to the major-general, and he is far outnumbered in the lists by the other justices. So it seems that the officers were at work but that their efforts were not immensely more effective or vigorous than those of the JPs. Also, the sessions with the largest number of drinkrelated presentments from the hundreds, Summer 1654, preceded the major-general's "rule" and was not even during the period when their commissions were being prepared or conceived. ${ }^{327}$ Considering a fairly standard level of about eight presentments from the hundreds, it seems that the commissioners had an effect. But the diligence of constables and justices alone—or perhaps just a hot summer—could account for an equal or even more significant increase in regulative, or perhaps so-called "moral," action.

Considering the actual contents of the instructions coming from central government, the very limited time and limited attention given by the major-generals to moral reform seems hardly surprising. Major-general John Desborow, one of the three most important army officers in the Council along with Charles Fleetwood, the Protector's son-in-law, and John Lambert, author of the Instrument, sent the majorgenerals a set of clarified instructions early in 1656. One of those instructions is to ensure that "No house standing alone outside a town is to be allowed to sell beer, ale, or wine, or to give entertainement." Other instructions direct that those who "live

\footnotetext{
${ }^{326}$ ERO, Q/SR 368/76.

${ }^{327} \mathrm{ERO}, \mathrm{Q} / \mathrm{SR} 362$.
} 
dissolutely or without a calling...give bond," that if any one gives the major-generals notice of "robbery, murder, or breach of the peace...use your utmost power to find them out," that they should "suppress all tumults, insurrections, and rebellions," "disarm all Papists...and stow their arms in a safe place," and "find out all thieves, robbers, highwaymen, and other dangerous persons." The directive is anything but a laundry list of directions to effect a moral reform; instead, it reads like a list of standard law enforcement priorities—and directives to take action against disorder. The only directive of the fourteen in the instructions which directly addresses "moral" reform is that the officers are by their "constant carriage and conversation, to promote godliness and discourage profaneness" and "laws against drunkenness, blasphemy, and swearing...and such wickedness, be effectually executed" and sent up "to the justices of the peace." Though the list does include some mention of preventing the opposite of godliness, i.e.: "wickedness," all of the other instructions were directly related to order. If the officers were there primarily for the purpose of "reformation of manners," reformation strangely included collecting weapons and apprehending highwaymen rather more than ensuring the Lord's Day was not profaned. On the same day as the list of instructions to the major-generals, the Council also directed the major-generals to engage in another task to improve security. They directed that "all who...come here from beyond seas shall, within 24 hours of landing, give in to such persons as the Maj.-General...their names and places...and the parish, street, and house where they intend to live." It seems that rather than making the counties safe for godliness the major-generals were required to act as border police to prevent plotters and spies from sneaking into and around the country. 
Based on the instructions from the Council, it seems the major-generals deserved the moniker "customs agent" as much or more than the label "godly reformer."328

Keith Wrightson analyzed crime patterns in Essex in the mid-seventeenth century in terms of the Puritan "reformation of manners." His longitudinal study of quarter sessions prosecutions from which true bills were returned for the period reveal some change during the major-generals' period, particularly in regards to regulative issues. That analysis for the Interregnum includes the years 1650, 1652, 1654, 1656 and then 1660 and 1662. Compared to the other years, in 1656 - the one full year the majorgenerals worked in the counties-differences in prosecutions for what he termed interpersonal disputes: theft, assault, trespass, disseisin, and poaching were completely unremarkable. 1650 and 1660 were the years with the largest number of thefts with forty two and twenty three respectively, whereas 1654 and 1656 were the highest for assaults with sixteen, though only 1650 recorded fewer than ten. In terms of obligation enforcement—roads, bridges, and neglect or abuse of public office-1656 is not different from the other years. In terms of regulative prosecutions, though, 1656 is significant; however, this is because of an increase in violent crime, rather than a Puritan “crackdown."

Unlicensed ale selling, fornication, drunkenness, swearing, and such trespasses showed no increase, though the twenty bills for disorderly alehouses returned to the levels seen in 1650 (15) and 1652 (18) compared to those of 1654 (6) and 1658 (3). 1660 brought fifteen before falling to an average of five per year for the rest of the period Wrightson analyzed, which ended in 1666. Considering the influence of the presence of

${ }^{328}$ CSPD, 9:103-4. 
an army officer and a former major-general on the bench throughout 1658, it seems surprising that there was no increase in that year, which reported the second lowest number of true-billed prosecutions for the years 1650 to $1664 .^{329}$ The largest increases in the year 1656 were a slight but noticeable jump in bills for non-attendance at church, but the most significant increases were for taking inmates, cottaging, and violating the statute of artificers. ${ }^{330}$ Indictments for these violations were, however, fairly consistent with the rest of the period 1626 to 1666 , as was the case with those for interpersonal disputes, roads and bridges, and neglect or abuse of office by constables, bailiffs, etc. ${ }^{331}$

In terms of the sort of regulatory activity favored by Puritans, Wrightson found that it was not under the major-generals but rather twenty five years earlier in 1629-1631 that the most vigorous activity against immoral conduct appeared. Disorderly alehouses and "assize of ale" 332 together increased seven-fold compared to the years before or after that triennium. Default on road work was also two to three times higher than in most other years (excepting 1646), and decayed roads and bridges were indicted at approximately double the norm. In 1630-1, the most reformative years, abuse or neglect of office was three or four times what had been seen previously. For Wrightson this indicated a push to increase order in years when order may have been threatened as a result of dearth and famine, and the increased pressure on constables was likely due to Puritans on the benches. In Lancashire during the same period there was very little

\footnotetext{
${ }^{329}$ True bills were matters than the grand jury deemed worthy of indictment in evidentiary terms.

${ }^{330}$ Taking inmates regarded taking people in who were not family of the property owners and were not members of the parish. Cottagers were persons who erected houses, usually on public lands or "wastes," which had less than four acres of land. The statute of artificers dealt with commercial violations, such as persons operating a business who had not been properly licensed or apprenticed.

${ }^{331}$ Brewer and Styles, An Ungovernable People, appendix to Chapter 1, 300-303.

${ }^{332}$ Assize of ale regarded selling in accord with legally mandated measures.
} 
difference or unusual activity in either the 1650 s or the 1620 s and 1630s. A dramatic jump occurred, however, when quarter sessions resumed again after the First Civil War. Alehouse offences in Lancashire were dramatically higher in 1646-1651, and recusancy leapt in 1648 and 1651 after years of relatively mild vigilance in this regard. ${ }^{333}$

These statistics indicate a variety of factors in justices' attempts to pursue order through the local judicial machinery. In Essex and Lancaster, the prosecutorial jumps during 1629-1631 and 1646-1651 indicate that more vigorous JPs-likely Puritangained control of the benches: the first in progressively puritanizing Essex during a period of dearth and disorder, the second in relatively conservative and Catholic-leaning Lancashire after the Royalists were defeated and local Puritans from the cloth area took control. ${ }^{334}$ Most significantly for the study of the major-generals' effect on the county, neither Lancashire nor Essex showed significant increases in 1656-8, particularly when compared to the earlier period. Based on these statistics, any puritanizing under the thumb of the major-generals seems paltry compared the pressures of ten or twenty five years earlier. If the major-generals were "bashaws," they were bashaws with little power. ${ }^{335}$ Instead, the real bashaws were the pre-Civil War justices. The 1629-31/16461651 increases in Lancashire and Essex had brought an increase in presentments in tandem with indictments of minor officers—constables, bailiffs, etc.—-for failure in their duties, which meant that the increase in presentments was likely due to justices prosecuting those who were remiss in their duties regarding reporting on violators. The appearance of the major-generals and their dozen or so commissioners in each county

\footnotetext{
${ }^{333}$ Brewer and Styles, 300-303.

${ }^{334}$ Wrightson, "Two Concepts of Order," in An Ungovernable People, 23-25, 37, 46.

${ }^{335}$ Brewer and Styles, 300-303.
} 
seems not to have fired a similar response or increase, at least as reflected in court records. Whatever the enthusiasm of Hezekiah Haynes and his fellows, a vigorous new godly reformation seems not to have come on the heels of the major-generals.

Because the government changed during the Civil Wars and Interregnum, it is difficult to make exact comparisons between periods, and historians have often avoided or ended their studies at the beginning of this period. In Wrightson's study of Essex, the period 1629-31 saw a swelling of indictments for alehouse and related offences.

However, the number of indictments in quarter sessions dropped significantly overall in the 1640 s and 1650s. But, as noted above, sources other than court indictments seem to indicate there was a strong interest in alehouse violations during the Interregnum period. That interest may not be reflected in studies that counted indictments because practices in dealing with alehouses and social order crimes seem to have changed. It appears that in Interregnum Essex, and probably elsewhere, there was a preference for dealing with minor social order offences via quicker and less judicially onerous means. Thus, though it appears from a count of indictments that business dropped, the combined records indicated a difference in enforcement strategy. Therefore, any increases or fluctuations are shown in presentments from the hundreds, gaol deliveries, and recognizances. The advantage for justices of avoiding indictments was that, rather than waiting for the quarter sessions, or even a monthly petty sessions, the violations could be dealt with "on the spot." The 1655 edition of Countrey Justice, the published reference work which all JPs owned and which served as a basis for their work, details these alternatives. In the matter of the regulation of drinking, Countrey Justice recommended that 
Any Justice of the Peace in any County (and any Justice of the Peace or other head Officer, in a City or Town corporate, within their limits) shall have power (upon his own view, confession of the party, or proof of one witnesse upon oath) to confince any person of drunkennesse, whereby such persons to convict shall incurre the forfeiture of five shillings. ${ }^{336}$

Justices, therefore, had that power to convict not only those who were drunk but also those who helped drinkers "on their way:" unlicensed alehouse keepers. Countrey Justice advises that they be dealt with by a similar procedure, with similar results, similar penalties, and as little need to resort to formal indictment as those who were caught in a state of intoxication.

[The] same offence being viewed by any Justice of the peace (Mayor or other any head Officer of any City or Town corporate) within their limits, or confessed by the offender or proved by the Oath of two witnesses. Every such Justice of the peace (or other head Officer aforesaid) have the [that] power. ${ }^{337}$

The sessions book in Maldon tells of a 1654 case involving "Ann Penson widdow of maldon" who "standeth convicted for taking upon her com[m]only to sell beere in her dwelling house in the p[ar]ish of maryes in maldon (upon her owne authority not being thereunto lawfully licensed). ${ }^{, 338}$ After conviction Justices were allowed to commit an unlicensed alehouse keeper to the gaol for three days. But jail had apparently proved to be an insufficient penalty, probably since those who sold ale for part of their living every day of the year were unlikely to be long deterred from such by only three days in the clink. Realizing the relatively toothless nature of such a sanction, the statutemakers in Parliament—who were usually JPs with long experience of the issue—devised

\footnotetext{
${ }^{336}$ Michael Dalton, The Countrey Justice, containing the practice of the justices of the peace out of their sessions (London, 1655), 31-2. Wing D144.

${ }^{337}$ Dalton, 31-2.

${ }^{338}$ Maldon SB, 202.
} 
a further means to dissuade those who profited from unlicensed selling, as discussed in

\section{Countrey Justice.}

This former law made, $5 \mathrm{Ed}$. 6. hath not wrought such reformation as was intended, it is further enacted...(that) every such person for such offence, shall forfeit twenty shillings to the use of the poor of the Parish where such offence shall be committed. ${ }^{339}$

Ann Penson was so held to account, the Maldon book recounting her penalty by stating, "whereby she hath forfeited 20sh for the poore of the said p[ar]ish." ${ }^{340}$ Rather than jail, for the justices this was a crime with a significant silver lining: it allowed them to give the community some relief on the poor rates.

The county sessions order book is full of complaints from parishes begging for poor rate relief, and that book also contains many orders chiding constables and churchwardens for not collecting or distributing the rates properly. Diarist and minister Ralph Josselin, despite having an income of more than a hundred pounds per year-some of which was procured for him from the central government via Major-general Haynes as an augmentation — complained about the burden of the rates. He recounted that on March 14,1655 , an $\mathrm{H}$. Abbot junior came to collect a rate of 26 shillings. After much pleading and discussion, Josselin reported with great satisfaction that he was excused, writing "he presently kindly crossed my rate...I blesse god." 341

Since one unlicensed house could spell relief for one godly minister, it is hardly surprising that justices preferred the fine which paid the poor rather than a gaol sentence which meant the parishes had to feed the alehouse keeper while he was in custody. And

\footnotetext{
${ }^{339}$ Dalton, 31-2.

340 Maldon SB, 202.

341 Josselin, 342.
} 
there was significant motive for those caught providing sauce to tipplers to play along with justices employing such methods. Country Justice goes on further to say that if the “offender...shall not pay the said twenty shillings within six days after such conviction, then the said Justice" could send the "party apprehended to be openly whipped.",342

Having been caught and fined, the unlicensed keepers would be required to turn up at the quarter sessions, where the bench "shall certifie such Recognisance, discharge, and office, at their next quarter sessions: where certificate shall be a sufficient conviction in the Law of the same offence, without any further triall thereof to be had." ${ }^{\text {343 }}$ This was a much easier and more effective means of dealing with the issue than a full indictment which might require witnesses, who were notoriously unreliable in presenting themselves outside of their local communities for such matters. The quarter sessions in the 1650 s are largely without indictments on the matter of illegal drinking, but the hundred presentments regularly include them. It is only by considering these latter sources that one can derive an idea of the prevalence of illegal alehouses, the enforcement activity, and the attitudes and reactions of local government to alehouses. Presentments for order offences-like alehouses — do not necessarily surface at the formal indictment level, but they do reflect both the activity and the response to it at the local level.

Maldon was one of the more important towns in Essex. Being such, if there had been a very stringent push to increase prosecutions everywhere, one would expect increases in prosecutions in Maldon as well. But this was not the case. During the period in which the major-generals were active, there were no violations listed at all. The only

\footnotetext{
342 Dalton, 31-2.

${ }^{343}$ Dalton, 31-2.
} 
unusual activity following the new instructions of 1655 was the case of Benjamin Nussey. The order book recounts that "upon sufficient witnesses produced here in court by the iudgment" of the officers of the court, the accused "standeth comitted for being drunk within the burrough upon the third day of April last past before the holding of the said Sessions." Being drunk on a day of the sessions was probably not an especially unusual condition for a citizen of the Essex town. The unusual element of this particular case was the accused's position as one of the headburgesses. The councilman in question seems not to have been deprived of his post. Instead, the order book recorded that he "hath forfeited to the poore five shillings according to the lawe." 344 Other townsmen who were caught drunk around the town could be similarly fined by an officer of the court or constable, as was the custom. ${ }^{345}$

But apparently the members of the town court and council thought Nussey's matter important enough to mention, but not important enough to prompt severe action. The entry in the order book shows their attention to such matters-even and perhaps particularly if it were one of their own - and that restoring good order to the community, or the council in this case, was important. It also shows that though there were no presentments for illegal alehouses while the commissioners were actively working in Essex, there was some enforcement activity-which means there was not a total blackout on drink enforcement. Had the major-generals been on hand when Nussey was caught drunk at sessions, they might have requested a harsher penalty, as some had rather negative opinions regarding the quality of justices and town officers. But if the Maldon

\footnotetext{
${ }^{344}$ Maldon SB, 218.

345 Dalton, 31-2.
} 
records over the next year or so are any indication, the commissioners must have missed the town-despite the free lodging which would have been available at the Redd Lyon or its other licensed establishment—or they did not find anything there that was worthy of their attentions.

\section{Other signs of the major-generals' influence}

Overall during the major-generals period it seems that in Essex there was some increase in prosecutions for illegal alehouses, but it was both rather limited and spotty. Also, the activity of the officers seems not to have had the same capacity to effect significant change as the crackdown of 1629-31, which was accomplished not with the help of "swordsmen" but only by the efforts of JPs. It is important to note, however, that Haynes at least did not sit at the quarter sessions at the time, although he was listed at the Assizes. ${ }^{346}$ He had been listed on the Essex commission of the peace, as reflected in the assize records, for some years, but his name generally appeared near the bottom of the list, whereas the most important figures were towards the top. This changed for the winter assize of 1656. During the first assize of the period of the major-generals, Haynes' name follows immediately after the assize judges, who came from London to hear the cases, and before that of Henry Mildmay of Graces, one of the most important gentry figures in the county. Most of the assize seems to have been business as usual; there is no great increase in alehouse indictments or presentments. However, seven men were charged with being common swearers or cursers. One might attribute this to the commissioners and the presence of the major-general, but the date listed for the offence is

\footnotetext{
${ }^{346}$ QSOB, passim.
} 
July $1^{\text {st }}, 1655$, prior to the arrival of the major-generals. ${ }^{347}$ It is possible that Haynes or other justices decided to bind them over once the major-general was at his work, even though the offense had occurred earlier. Or perhaps the charges were brought in by or under the direction of Haynes, who had been the regimental commander in East Anglia prior to taking his post as major-general. Unfortunately there are no further details recorded. But this is the only factor which distinguishes this particular assize from any other in terms of moral regulation.

Unfortunately there is no available record for the Summer assizes of 1656. But in the following March, there is a notable difference in one aspect of the winter assize of 1657. Rather than a significant difference in prosecutions, there is a difference in punishments. Most of those who were brought up on serious chargers had guilty verdicts returned, and nearly all of those who could have been sentenced to hanging were indeed hanged. ${ }^{348}$ In his research in Devon, Stephen Roberts uncovered a similar result. The cause for the increase may have been the reform of jury selection at the time, brought about because juries were often considered either corrupt or unreliable. ${ }^{349}$ At the Council's request, major-generals and commissioners made more of an effort to find men who were considered "honest and true" to serve as jurors. ${ }^{350}$ So rather than the presence of a watchful major-general frowning on the proceedings, the harsher punishments might have indicated that the commissioners, engaging in one of their many ancillary tasks, had succeeded in securing juries which were more conscientious or perhaps reliably stern.

\footnotetext{
${ }^{347}$ Assize files, 35/97.

${ }^{348}$ Assize files, 35/97.

${ }^{349}$ Cockburn, Assizes, 102-104.

${ }^{350}$ Stephen K. Roberts, Recovery and Restoration in an English County: Devon Local Administration 16461670 (Exeter: University of Exeter, 1985), 52-53.
} 
Though most hanging offences were violations of the ten commandments, a tougher jury hardly represents a push for godly reformation. Rather, it does indicate further efforts to decrease disorder through improving justice.

\section{The major-generals' aims: social order or morality?}

It is not too much of an exaggeration to consider all of the JPs' activities to be concerned with order: order of accounts, order of the roads and bridges, order in the parish rates, order of the churchwardens, and the list goes on. Matters such as alehouses, vagabonds, parish rates, scolds, etc. had long and repeatedly been proscribed by the law: so to some extent the attention of the JPs to such matters, particularly if the offense was minor, was discretionary. The wise JP would not go looking for troubles, statute book in hand. Rather, problems would come to the JPs' attention and they would look to their knowledge of the statute to find an appropriate remedy. Most minor offenders could get away with their petty malfeasance as long as they stayed off the radar. But once a JP's interest was aroused by personal or communal concern, the process of controlling disorder via the procedures of justice would begin.

Another way of controlling disorder involved small matters which often did not cry loudly enough for justice but could be brought to JPs' attention as further punishment for other crimes. Local administrators were tasked with making sure the roads, highways, and many Essex bridges were properly repaired, and falling foul of lending a hand in maintaining such throughways could bring one down with a splash, though in the quarter sessions in front of the local gentry rather than the mucky riverbeds of the county. Presentments for refusal to work on the roads was a common matter brought before JPs, 
and in Easter of 1654 a yeoman, Richard Brighte, of Great Canfield found himself included in the grand jury presentments. He was indicted "for neglecting and refusing to work in the repair of the highways." But for the persons on the grand jury who brought him up, a disinclination toward doing his part on the highways was not enough. He was also presented for being "a common tippler, swearer and profaner of the Lord's day."351 As it was presented with another case of road negligence it seems that his being found out for moral offensiveness would not have taken place had he helped on the road. The Sabbath and tippling offenses are often included with failure to work on the roads, cottaging, or being a disorderly person. Some of the ungodly moral offences-swearing, recusancy-became apparent, it seems, only if there were additional reasons to call the reprobate to account. Instead, it seems that those were included as additional evidence of the depravity of the miscreant.

This happened to Boxted man Christopher Hauken, who was presented "for erecting a cottage on the Heath and there living very suspiciously and doth not attend any order of divine worship neither private nor public, and will not suffer his wife to live with him." 352 William Huland senior of Tollesbury similarly found himself presented by the jury of the hundreds of Lexden, Tendring, Winstree and Thurstable for "taking in part of the Heath," which was common land or "wasteland" which some thought it their right to cultivate and include in their property. Also included in the presentment was the

\footnotetext{
${ }^{351}$ ERO, Q/SR 360/23.

${ }^{352}$ ERO, Q/SR 360/28.
} 
accusation that he "entertaineth many idle and suspicious persons and doth not attend any

public 'ordances', but spend the Lord's day in idleness." 353

Again, it seems that breaking the administrative rules was the best way to have oneself prosecuted for immoral activity. Cottaging and enclosing wasteland were administrative offences against also represented a threat to order, for they were often engaged in by persons from outside the community who were not known and did not come under the normal property or manorial restraints. No one knew what the unknown outsiders were doing and they did not adhere to an "orderly" way of life, so they were brought to the justices for censure or removal. In the cases of Hauken and Huland, their lack of adherence to the administrative or moral rules — tippling, idleness, recusancywere all part of their disorderly lives. Similarly, Thomas Raynor of Rast Donyland was presented 'for being drunk and coming to the public 'Ordanaces' on the Lord's day in drink." ${ }^{354}$ In his case, as perhaps the others, his irresponsible behavior and his unreligious behavior were considered related crimes, and it seems likely that a local busybody might have brought the matter to the JPs' attention. Though it is impossible to interrogate the juries of such matters further, the connection of the various wrongs suggests that administrative trespasses and moral offences were not only connected, but both could be viewed as a threat to the safety of the community as a whole.

\section{Legitimacy and disorder: ministers and Quakers}

One of the difficulties during the period was that the traditional grounds of authority had been undermined, and once that had occurred, the door was open to endless

\footnotetext{
${ }^{353}$ ERO, Q/SR 360/28.

${ }^{354}$ ERO, Q/SR 360/28.
} 
challenges. At the outset of the Civil Wars, Parliament had fought the king, claiming that the laws of the "kingdom" rested in the king through not only God but their authority as well. Then they had executed the king, whose authority was rooted in the divine, and replaced the "kingdom" with the republican commonwealth. Then, as noted in the Introduction, in 1653 Cromwell had dissolved the Rump Parliament and the subsequent Barebones Parliament, and replaced the authority of Parliament with that of the Instrument of Government, which had not even received Parliamentary sanction. Cromwell had the reins of government under the Instrument, but there was endless disagreement on whether he had the right to claim authority and also whether that authority was morally or legally right—even among the godly.

The government's power rested in part on the army, but its deeper legitimacy stood on rather thin ground, nothing really more than the principle of "good government" and the idea of a republican commonwealth which did not have a functioning representative body. Ecclesiastical authority rested on even shakier ground since there was no cohesive church doctrine, and the government allowed and supported reasonably godly ministers who were not either popish or blaspheming. Institutions resting on such shaky ground were susceptible to challenge, and they were challenged in the presses, sometimes in the pulpits, occasionally and meekly at arms, and variously in the streets and shires of the nation. In his scaffold speech, Charles I had predicted as much, saying that if "you do put the people in that liberty...certainly they will never enjoy themselves." 355 In the shires, justices were able to rely on the practice of common law based on the earlier Stuarts. But adhering to this tradition did not mean that all

${ }^{355}$ King Charls his speech made upon the scaffold at Whitehall-Gate, (1649), 6. Wing C2792. 
recognized the authority of this tradition, and the local authorities would be contested in some of the same ways as central government. The parish churches were in a similar position. They were filled with ministers who were generally chosen by the locals and approved by the government. But for many people during these intolerant times simply being a Protestant, or a Puritan, was not enough. By the middle of the Interregnum, "disorderly persons" began openly challenging authority in the shires.

Once figures commanding great respect, and certainly once protected by the authority of the ecclesiastical courts, ministers suffered significant abuse during this period. That abuse was marked both for the variety and type of complaints. As with other minor order offences, these frequently did not reach the level of indictments and were dealt with exactly as they were dealt with on the national level—a spell under lock and key, and then release on a surety and a recognizance to cause no further trouble. Just after the New Year in 1654, Dionysus Wakering committed Mary Coale to the Colchester Castle for "raising many scandalous reports of a godly minister which she herself hath confessed all to be false and untrue." Additionally, and perhaps this goes without saying, she was also listed as being a "disorderly and idle person.,"356 The gaol and court records at the time, as in this particular account, do not give an indication of what those terms meant precisely. Naturally, the meaning of "idle" is not difficult to discern, but this particular phrase with its close association of these two words appears frequently in the sessions rolls. The pairing indicates the general deformity of the person's nature. Being idle was sinful and the cause of disorderly_and thus dangerous—-behavior, but it also shows the extent to which those persons were thought to be an incipient if not immediate

${ }^{356}$ ERO, Q/SR 359/70. 
danger to the community. Berating the minister was the result of the nature of the person in whom such an attitude of disrespect would arise.

Attacks on the clergy became a rather common occurrence as listed in the court records, and in the 1655 case of falsely-accused minister Daniel Barfoote, Arthur Cowland slanderously used a Rump Parliament statute punishing sexual license in an attempt to undermine the preacher.

Daniel Barfoote of Cressing clerk, was and is by the space of 10 years last past a minister, and preacher of God's most holy word, and hath been and now is an honest man of good name from the time of his birth, and hath always behaved and carried himself as an honest, pious, godly and religious person without any crime of adultery, incest and fornication[.] $[\mathrm{N}]$ evertheless Arthur Cowland of "Chatley hamlett" in Great Leighs, labourer, knowing of the premises but going about maliciously intending not only to deprive Barfoote of his good name, but to bring him into danger of [the] penal statute lately made for the suppressing of the detestable sins of incest and adultery and fornication[,] at Crossing, falsely scandalously, opprbriously and maliciously in the presence and hearing of divers honest and credible persons, did speak of Barfoote these false and scandalous words, "Young Barfoote was [now] with the widow Marsh (meaning Dorcas Marsh of Cressing widow) and she is his whorse. ${ }^{357}$

Realizing that the jig was up once he had appeared before the justices, Cowland "put himself in the favour of the court" and paid a fine of five shillings. This episode of a man not only criticizing and speaking poorly of a minister, but actively trying to have him prosecuted, was a particularly egregious example of how respect for the authority of the clergy had diminished. As mentioned previously, some reduction in the status of the clergy would have been expected, since challenging the legitimacy of the traditional ecclesiastical authorities — the bishops_-was a major aim of the Long Parliament. Yet however understandable such challenges were under the political circumstances, local

${ }^{357}$ ERO, Q/SR 364/12. 
authorities would have none of it. Belief might have become free for tender consciences, but open debate or the shouting down of ministers was not allowed. Though the church had been partially disestablished, the justices and the gentry were not willing to countenance either the positions of clergy in the parishes or their own authority being undermined.

One of the greatest sources of this sort of defiant disorder was the Quakers. They were perhaps the sine qua non of troublesome Interregnum dissenters. A large section of the general population was fairly content to countenance a variety of religious opinions provided popery, leveling, or Anabaptists were marginalized or removed. Those were views which Cromwell held. But the moderate or even so-called radical sects, the Independents and Baptists, found the behavior of the disciples of George Fox to be a worrisome threat to order. ${ }^{358}$ They were the most fervent of those who opposed tithes, ${ }^{359}$ and they were famous for entering churches and shouting down the minister. Ralph Josselin fretted over the possibility of encounters with Quakers in the pulpit or the streets, even wondering if they would be a threat to Cromwell's government. On July $3^{\text {rd }}, 1655$ Josselin wrote that he "preacht at Gaines Coln the quakers nest, but no disturbance, god hath raised up my heart not to feare...it is an evill that runs much in all places."

The following day an event occurred which was not only an excellent example of the sort of disorder that JPs and others in the community feared, but it would lead to what seems an unfortunate episode which would blacken the reputation of the Interregnum

\footnotetext{
358 John Coffey, “The Toleration Controversy During the English Revolution,” in Durston and Maltby, 53.

${ }^{359}$ Barry Reay, "Quaker Opposition to Tithes 1652-1660," Past and Present 86 (February 1980): 98-120.
} 
government as bloody and oppressive zealots. ${ }^{360}$ Earlier that week two Quakers, one of whom was James Parnell, disrupted the parish service at Coggeshall. Their court indictment read that they "published certain "false and scandelous papers, writigns and pamphletts' and interrupted William Sparrow minister when he was preaching." ${ }^{361}$ When presented in court, Parnell also berated the Essex justices, which led to his being indicted for contempt. According to the records of the assize where he faced the majesty of the circuit court, he had told Essex justices Herbert Pellam, Thomas Cooke, Dionysus Wakering, and William Harlackenden,

You are unjust Judges and Lawyers and what law and justice can I except from such uniust Judges and Lawyers [a]s you are for you doe cast mee in [into gaol] contrary and without law. Its like you will proced contrary and without Law. And you blinde heavy burthens and lay them uppon the oppressed. And you make lyes your refuge soe that you are corrupt rulers. ${ }^{362}$

Parnell had thus done everything possible to disturb the order of the community, though it can be said he did it in a completely "moral" way without resorting to any sort of sinful behavior. Yet this was too subtle a distinction for the justices, and the disturbance was significant enough to be reported the following day in Josselin's diary. "Those called Quakers whose work is to revile the ministry, made a disturbance at Cogshall, and were sent to gaol, the good lord direct us what to doe, and keepe down violence in all spirits." ${ }^{363}$ What happened in Coggeshall is a prime example of what Josselin feared from the Quakers, whose activities would haunt him in the months and

\footnotetext{
${ }^{360}$ Parnel [Parnell], James (bap. 1636, d. 1656)," Adrian Davies in Oxford Dictionary of National Biography, (Oxford: OUP, 2004); online edn, ed. Lawrence Goldman, January 2009.

${ }^{361}$ Assize files, T/A 418/146/32; Assize files, 35/96.

${ }^{362}$ Assize files, T/A 418/146/33.

${ }^{363}$ Josselin, 349.
} 
years to come. Two weeks later he reported trouble from the sect at his own parish church "The Quakers set up a paper on the church door at E. Coln lord I and people and truths Are thine, I pray the[e] take care of them, and give mee wisedom to behave my selfe wisely, in they worke, and among thy people." The next day he notes "this corner begins to feel the quakers[,] some of their heads its said are among us, the lord bee our refuge."364

For the next few months other matters seem to have been more worrying for Josselin, whose diary contains entries about the massacres of Protestants in Piedmont and many mentions of international events in Poland and Spain. Gaol delivery for the March assizes lists Parnell as still in custody for non-payment of his heavy fine. Yet imprisonment of one of their leaders had not prevented the continued growth of the movement in the county, and the fear of Quakers pops up again in Josselin's diaries in April 1656 after a trip to Colchester. "Quakers increase, profanes doth not decrease[,] strange for persons to bee silent, not speake when saluted or spoken unto, the lord good to mee in the word this day." 365 He feared the spread of the spiritual malaise into a local family. "Heard and true that Turners daughter was distract in this quaking busines, sad are the fits at Coxall[,] like the pow wowing among the Indies" ${ }^{366}$ He feared that he and his fellow clergy were being stalked, and might be set upon by the growing sect. "There are some that know the puritans haunts that will take a course with them, unles they walke wisely and circumspectly." ${ }^{, 367}$ Even Robert Rich, Earl of Warwick, one of the most

\footnotetext{
${ }^{364}$ Josselin, 350.

${ }^{365}$ Josselin, 366.

${ }^{366}$ Josselin, 366.

${ }^{367}$ Josselin, 365.
} 
powerful godly nobles in the country, had a Quaker committed for "misbehaving himself and several times disturbing the minister and congregation at Felsted." 368

As the Quakers increased their activities, the condition of their prophet in the Colchester Castle declined. Following a variety of mistreatments, harsh conditions, and a religiously-motivated hunger strike, the young Parnell expired. The next day Josselin commented, "James Parnell the father of the Quakers in these parts, having undertaken to fast 40 dayes and nights, was die. 10. in the morning found dead, he was by Jury found guilty of his own death...I tremble at his folly." ${ }^{369}$ A few days later a letter from Charles Fleetwood arrived ordering his release. Josselin seems to have been genuinely saddened by the young man's death, but worried about the encouragement such a release might have provided for his raucous sect, guessing "had he been delivered the triumph his partie would have made."370 It is unlikely that the justices had any hand in Parnell's harsh treatment. But they did levy a heavy fine and refused to let him out even on the surety offered by a friend. ${ }^{371}$

Considering the amount of trouble his followers had caused, it is unlikely that they would have been keen to let him roam around the shire, especially if they had been familiar with his writings such as Trumpet of the Lord Blowne. Or, A Blast Against Pride and Oppression and the defiled liberty, which stands in the flesh which began

Woe unto you that are called Lords, Ladies, Knights, Gentlemen, and Gentlewomen, in respect to your persons who are exalted on the earth, who are proud, and high, and lofty... which by fraud, deceit, and oppression you have gotten together...grind the faces of the poore, and

\footnotetext{
${ }^{368}$ ERO, Q/SR 369/118.

369 Josselin, 366-7.

${ }^{370}$ Josselin, 367.

371 "Parnel," ODNB.
} 
they are as slaves under you, and must labour and toyle under you, and you must live at ease... according to your lustful minds. ${ }^{372}$

The pamphlet continues as a scripture-filled philippic against the social elites-exactly the class from which the JPs themselves came. In those disconcerting times when the country seemed to be filled with the sorts of rumors and signs of ominous events as had been common before the outbreak of the Civil Wars, Parnell's direct attack on the propertied would not have been well-received, particularly considering the quick growth of the sect and its assertive moves to censure the ministers in public before entire parishes. The end of Parnell's tract could not have but cemented in the minds of the justices the potential danger as a source of social rebellion that the Quakers represented.

Now all you high and lofty...scorning and disdaining your fellowcreatures, read your selves and your portions, howle and lament, for a day of vengeance, of rending, of burning of famine, is coming up on you, for the land mourns because of pride. ${ }^{373}$

As in Bristol and other towns, in Essex the outbreaks of disruptive Quakers would have only heightened the sense of the increasing decay of order. Though the Council of State was disinclined to oppress the Quakers harshly, and their leader George Fox had met amicably with Cromwell and discussed the former's faith, the disruptive acts of the Quakers would have added an additional layer of unease to the counties. It was under this perceived threat that the JPs let Parnell wither and die in gaol. Certainly it was wrong, and the justices were particularly quick to determine that Parnell had caused his own death. ${ }^{374}$ But his commitment to gaol by the JPs was not malicious; it only revealed

\footnotetext{
${ }^{372}$ James Parnel, The trumpet of the Lord blowne. Or, a blast against pride and oppression, and the defiled liberty, which stands in the flesh (London: Giles Calvert, 1655), 1.

${ }^{373}$ Parnel, The trumpet of the Lord, 6.

374 "Parnel," ODNB.
} 
the extent to which the gentry felt that disorder threatened in the county and their belief that something had to be done to combat it.

After Parnell's death, JPs at the Chelmsford quarter sessions took a further stand against the rebellious sect. In a long declaration in the sessions order book, the justices decried that "many idle, seditious and evill disposed person doe travaile and passe from County to County...seduceing and withdrawing many persons from their due Obedience to the good Government of this Nac[i]on." The book mentions that they "enter into [th]e publique Assemblyes of the good people" and also disrupt church services "and reproach, traduce and highly abuse with many invective railings and other opprobrious speeches the Ministers and dispencers of God's word and other of Gods people" and at other times "endeavor to vilify the said Ministers and to bring them and their ministry into disrespect."

Considering these great disorders, the court thought it necessary to intervene using the powers entrusted to the justices by their offices. "Forseeing and fearing the evill and danger that is like to arise and flow therefrom if not timely prevented" the justices directed the head constables to charge their petty constables with the "use of all possible Diligence to apprehend all such evill disposed persons" where they were found "wandering and haunteing from place to place" or did "revile and evill entreat any the said Ministers." The constables were required to bring any such offenders before a justice or justices, "and in case any the said Petty Constables or other Officers shall be negligent...to make retorne of such...they will answer the contrary att their utmost 
perrill." 375 Not only was the sect declared a threat to the nation and its security, but the justices put all their might behind the ordinance, threatening to punish any local officers who did not bring such offenders to justice. Having identified a danger to the peace of the community and the government, the county government-like central governmenttook action against the sources of disorder that threatened its power and, perhaps, its very existence.

There was a religious element in their battle because the threat originated in a radical sect which was actively engaged in disrupting the peace. But the reason the authorities acted against the Quakers was the level of disorder and the perceived threat to the social order the sect brought into the counties, not because the justices wished to marginalize a religious opinion, advocate for a faction, or instill godly reform in the people. The Quakers looked dangerously disruptive, and using the power provided them by the networks of local justice, the JPs aimed to disrupt their disruptions. Yet the order in the sessions book and whatever efforts followed did not cure the Quaker problem. Later in the year Josselin reported that "In the lane sett upon by one called a quaker, the lord was with my heart that I was not dismayed, I had some discourse with him.” Josselin was relieved to have acquitted himself well against an incidence of Quaker street ministry. ${ }^{376}$ Josselin's spirits were lifted when he further succeeded against the radical sect, reconverting a daughter of a local family to the traditional religion after she had dabbled in Quakerism. ${ }^{377}$

\footnotetext{
${ }^{375}$ QSOB, 88.

${ }^{376}$ Josselin, 384.

377 Josselin, 373.
} 
Efforts to subdue Quaker disorder continued throughout the Interregnum in Essex. As was the case with the prosecutions of Parnell, court records generally do not show the denominational inclinations of the accused so it is difficult to say with absolute certainty whether any particular instance of disorder was by a Quaker. But "quakerish" practices were regularly recorded in the court records through the later years of the Interregnum. One Mary Braddy incurred the wrath of Warwick and JP John Atwood for the usual Quaker shenanigans. She was committed to the castle for "wilful disturbing Mr. [Ra]new minister of Felsted in time of divine exercise and before he had pronounced the blessing after sermon and in public disturbance of the congregation" in September of $1657 .{ }^{378}$ At the subsequent Michelmas quarter sessions, her offence against communal and godly order was further elucidated. According to the indictment, as Nathaniel Ranew, clerk and minister of Felsted, was in the midst of delivering his sermon, Braddy shouted "You are a false prophet and I come to admonish you to repent." Her comment fell flat enough on the congregation, JPs, and jurors of the county to result in a guilty verdict and a onemonth stint in the house of correction for the opprobrious spinster. ${ }^{379}$

Such outbursts would continue in chapels in the county, and the rest of England, into the Restoration period and beyond. It is difficult to measure the effect of such words on the reputation of the government. But everywhere in the country and whatever their religious leanings, the gentry and lords, like Warwick, regarded the maintenance of good order and deference as a cornerstone of good governance, and good government could not permit the sort of disruptive antics favored by Quakers to go unaddressed. So it

\footnotetext{
${ }^{378}$ ERO, Q/SR 373/68.

${ }^{379}$ ERO, Q/SR 374/3.
} 
certainly could not have helped the government that such outbreaks of disorder were becoming increasingly common. Whitehall's policy during the Protectorate toward Quakers was actually ambivalent. Cromwell and his Council seem to have considered the Quakers a threat up to a point, and they certainly did not countenance the sort of disorder that the sect brought into the parishes and parish churches of the nation. But Cromwell, a tolerationist, did not believe in suppressing them completely. Instead, the political nation's conscience would be expressed in the next Parliament.

During the Second Protectorate Parliament the Quakers became one of the major issues discussed. James Naylor, who had ridden into Bristol in a parody of Christ's entry into Jerusalem, was convicted by the Parliament under the Rump statute against blasphemy. Despite Cromwell's preference for clemency, Naylor was convicted by Parliament and given exemplary punishment, which included whipping, branding, having his tongue pierced by a hot iron, and imprisonment. Though Naylor had been disowned by Fox, it is hard not to see Naylor's treatment as a reaction to Quakers in general and to the sort of trouble they had caused in the counties. ${ }^{380}$

Coming as it did on the heels of the 1655 rebellion which included intimations of support by religious radicals, the rise of the Quakers could not but have added to the call for further measures to increase order in the country. But the government's inability to deal with them would also not have endeared it to the gentry, who it needed for financial and political support. Josselin trusted the Protector to deal with the problem, who he said "feares them not," but the minister's worries reflected the mood of the Essex gentry, if not the country, when he wrote in July 1655 regarding the unruly spread and actions of

\footnotetext{
${ }^{380}$ Woolrych, Britain in Revolution, 648-9.
} 
the Quakers, "some think it will be dangerous to Cromwells interest." 381 Even to the extent that the various measures of the government, including the work of the majorgenerals, were generally not targeted at a particular sect, the disorder incited by that sect would have increased the overall concern for combating disorder and fears that the country was spinning out of control.

\section{Decimations and the "destruction" of the major-generals}

The second matter of concern to the gentry was the decimations. For the Royalists, the decimations were a violation of what they had been promised by the Act of Oblivion. And even though they were not part of the Parliament that had passed the act, they considered Parliament to be their voice - the gentry's voice-in government. An affront against some members of the group was an affront against all via the parliamentary principle. Levying a tax against them using a non-parliamentary ordinance which overrode a parliamentary statute was an offence against their common rights and liberties, and once those liberties were violated for some, others who were against the government in other ways - the Presbyterian party in particular-might have wondered if they were next. In his diary, Edmund Ludlow related a story of a decimated farmer who expressed as much.

And here I cannot omit to mention a farmer in Barkshire, who being demanded to pay his tenth, desired to know of the commissioners, in case he did so, what security he whould have for the other nine parts" and answer being made that he should have Cromwel's order and theirs for the enjoyment of the rest; he replied, "that he had already an Act of Parliament for the whole, which he could not but think to be as good security as they could give. ${ }^{382}$

\footnotetext{
381 Josselin, 348.

${ }^{382}$ Edmund Ludlow, Memoirs of Edmund Ludlow, Esq. (Oxford: Clarendon, 1894), 2:3.
} 
That tenth, decimation tax, fell heavily on Essex, which had the largest number of those paying the tax of any county for which records remain. Based on the charge of ten pounds per one hundred of income, all were of the MP and JP class. Approximately two-thirds of those on the decimation lists were counted as gentlemen or esquires, and it would be largely from that class that the JPs of the post-Restoration benches came: in January 1661, ten would be listed as knights and baronets, six as knights, and twenty as esquires. ${ }^{383}$ These men would certainly have resented their exclusion from Parliament during the Interregnum, as well as the combination of the additional tax with the Act of Oblivion of 1652, both levied by their social inferiors. They might have been perhaps less offended because Major-general Haynes, who had to levy the tax on his elder brother Robert, was from a minor gentry family in Essex. ${ }^{384}$ But some of the commissioners were not gentry, and the proud gentlemen of the county would certainly have been unhappy about submitting to further and potentially perpetual depredation from their inferiors, particularly after healing and settling had been hoped for and promised.

The tax and its implementation would have further soured the elite on the government, a feeling they would have expressed to the clients and fellows who voted against the government's "party" at the election for the Second Protectorate Parliament in 1656. The election went badly for supporters of government. Despite the ninety-odd men excluded from that Parliament because of their disaffection to the government, the

\footnotetext{
${ }^{383}$ QSOB, 192.

384 J. T. Cliffe, ed., "The Cromwellian Decimation Tax of 1655. The Assessment Lists," SeventeenthCentury Political and Financial Papers, D. R. Ransome, ed., (London: Cambridge University Press, 1996), 403-492.
} 
pressure from the counties was enough to defeat the Militia Bill which would have legalized the commissions for securing the peace of the commonwealth. ${ }^{385}$

The major-generals and Council of State convinced Cromwell to call a Parliament for autumn 1656. A variety of issues would be on their plate, including the raising of sufficient revenue to run the government and the military, and concerns about a potential war with Spain. Cromwell was actually perplexed as to why the major-generals and Council of State would call another Parliament when they had just had one-and an unsuccessful one at that. But being a supporter of the representative principle, he consented. The major-generals, particularly John Desbrowe, were anxious to seek Parliamentary sanction for their efforts in the counties. The Instrument of Government (and the Triennial Act passed in the first years of the Long Parliament) called for Parliaments only every three years. Calling that Parliament was something that the major-generals would come to regret. ${ }^{386}$

Writs for the elections were delivered, and the officers were confident. John Thurloe summed up their aspirations and fears well when he wrote of the elections to Henry Cromwell, "We hope for good from it; and that we shall have none of those, who during the last Parliament were continuing very bloody designs against the Protector and the peace of the nation." 387 His fears were for the safety of the government and the nation, the same fears which had prompted the Council to set up the major-generals in the counties. And very soon after elections were called, his hopes gave way to further anxiety. Almost immediately the government's opponents began to strive to win seats.

\footnotetext{
${ }^{385}$ Little and Smith, 107, 109-110.

${ }^{386}$ Little and Smith, 59.

${ }^{387}$ Little and Smith, 59-60; TSP, 5:213-214.
} 
Thurloe wrote to the Protector's son again: "Here is the greatest striving to get into Parliament that ever was known. All sorts of discontented people are incessant in their endeavors." The cry "noe soldier, decemator, or any man that hath a salary" was reported by Goffe in Sussex and a similar spirit prevailed throughout the country. ${ }^{388}$ Haynes from Norfolk expressed his fears that rebellion might come with the elections.

If other counties should do as this, it would be a sufficient alarm to stand upon our guard, the spirits of the people being most strangely heightened and moulded...I most humbly beg, that a speedy order may be taken for the paying and mustering of militia horses, for as yet they have not been called. ${ }^{389}$

The elections returned many open opponents of the government, but the elections were not a crippling defeat-at least not in Essex. Josselin reported that a Quaker disrupted the elections on the evening for which they were intended, but the poll was taken the following day, August $20^{\text {th }}$. The results were mixed. "The Independents plotted much in the choise but missed two men of their company, the choice view, is not very good nor very bad, a strange mixture of spirits." Like Thurloe, Josselin's primary concern was for the safety of the country, and he asked, "Lord...not suffer the nacion to bee wrapt up by thes men into any evill whatsoever." ${ }^{, 30}$ Josselin's account shows that eight of the thirteen returned for the county were JPs. Haynes, who had not yet served in the quarter sessions as a JP, was returned to Parliament as well.

But around the country, the enemies of the government had struck a blow. There must have been significant trepidation for the godly and the government as the sitting of Parliament approached. When the members convened, the Protector called Parliament to

\footnotetext{
${ }^{388}$ TSP, 5:341; Durston 341.

389 TSP, 5:328.

${ }^{390}$ Josselin, 377-8.
} 
an inaugural speech in the Painted Chamber at Westminster. He spoke at length in regard to his greatest concern: security. His primary concern is with the maintenance of the entire nation and its purpose beyond the limited scope of the British Isles. Rather than theology or matters of the spirit, he directed the Parliament to attend to practical matters. He wished to bring their attention to "things."

Truly our business is to speak of Things! The dispensations of God that are upon us do require it; and that subject upon which we shall make our discourse is somewhat of very great interest and concernment, both for the glory of God, and with reference to His Interest in the world. I mean His peculiar, His most peculiar interest...all these three Nations with their appurtences, or the countries and places belonging unto them. ${ }^{391}$

Cromwell also tells Parliament specifically that securing their very lives"preservation" of their "being"-is more important than confessional pursuits.

The first thing, therefore, that I shall speak to is that that is the first lesson of Nature, which is Being and Preservation. As to that of Being, I do think I do not ill style it the first consideration that Nature teacheth the Sons of Adam:--and then I think we shall enter into a field large enough when we come to consider that 'of' Well-being. But if Being itself be not first well laid, I think the other will hardly follow! ${ }^{392}$

It was life and limb, not fornication or swearing in the countryside, which was the greatest concern of the Lord Protector. Like many of the men to whom he spoke, the Cromwell had a conviction that the Pope and his allies were plotting endlessly to infringe upon right religion and English liberties, liberties which so many "saints" had given their lives to protect. As the Declaration of October $31^{\text {st }}, 1655$ had connected the rebels in the countryside to Charles Stuart, Cromwell connected the Stuart heir to Spain and popery.

"Why, truly, your greatest enemy is the Spaniard...led on by superstition and the implicitness of his faith in submitting to the See of Rome....For it

\footnotetext{
${ }^{391}$ Lomas, 2:509.

${ }^{392}$ Lomas, 2:509.
} 
is so now that Spain hath espoused that interest that you have all along hitherto been conflicting with, Charles Stuart's interest....can we think that Papists and Cavaliers shake not hands in England? ${ }^{393}$

The means by which Protector and Council of State dealt with the negative election results was a familiar one: exclusions. They wished to avoid deadlocks like that of the First Protectorate Parliament, and the Long Parliament as well. The Council of State vetted the list of MPs returned, and issued entry passes to those it wished to allow. The others were excluded. At first the members allowed to sit considered a protest on behalf of those who had been excluded. Yet after hearing Cromwell's speech, they decided against it and instead turned themselves to the business of behaving like a functioning Parliament. It was the lack of such seriousness that had prompted Cromwell to dissolve Parliaments previously, and in the new Parliament the exclusions prior to sitting would allow the members to get some productive work done. Nevertheless, this Parliament would spell the end of the major-generals.

Late in 1656 the major-generals, let by Major-general John Desbrowe, attempted to have their program approved by Parliament. Considering the election troubles, it perhaps seems strange that they would even try; but they must have had confidence because of the exclusions. Yet they still had their doubts, and to further ensure themselves of a majority the officers decided that Christmas, when many of the more moderate MPs would leave for celebrations at home, would be the time to have the bill giving them permanent sanction passed. Yet this attempt to pass the measure without the

\footnotetext{
${ }^{393}$ Abbott, 4:261-264.
} 
more moderate members failed; debate on the Militia Bill was postponed until the New Year. The measure was put forth again, and the debates were acrimonious. ${ }^{394}$

In those debates, the major-generals argued for the bill as a security measure, whereas the opponents argued against the so-called tyranny of the major-generals and the things they had done. ${ }^{395}$ For the major-generals, who had served on the battlefield and had fought beside many a "saint," the tax and militias were justified in the name of security from further rebellion and needless bloodshed. For the army who had fought in the Civil Wars, the Royalists of 1655-1657 were still the same enemy that fought the Civil Wars, were at the bottom of the recent rebellions, and had proven in 1655 to be the enemy still and thus deserved to bear the cost of the defense their disloyalty had necessitated.

For the opponents of the major-generals in Parliament, there were two main issues: the validity of the Act of Oblivion-which the tax clearly violated-and the redolent malodorousness of arbitrary government, something that Parliament had gone to war in 1642 to avoid. A variety of accusations were thrown about in the debates regarding abuses, though none seems to have been founded much in fact. Rather, they were the product of differing ideas about where the threat lay: the Major-generals sought the improvement of security to protect right religion and liberty against Royalists who had supported Charles I and his son. Many MPs, including many moderates, sought a return to traditional ways - as opposed to arbitrary, Charles I-style personal rule as

\footnotetext{
${ }^{394}$ Durston, 208-210.

${ }^{395}$ Durston, 210-215.
} 
represented by the major-generals-in order to protect right religion and liberty. In either case, both sides of the issue were fighting the ghost of the former king.

That ghost and those who sympathized with it ultimately brought down the majorgenerals. The bill was voted down 124-88, and what authority the major-generals had under the Instrument of Government was lost. The officers would return to their former commands, or London, and the JPs would go back to running their counties without the help—or interference — of the major-generals and their commissioners. After the defeat, Parliament immediately voted a $£ 400,000$ subsidy ostensibly for the war against Spain, certainly enough to help fund the army and navy for a spell, and enough to remove the necessity for a cut-price defense option. ${ }^{396}$ In March, several weeks after the majorgenerals' Parliamentary defeat, Cromwell discussed the matter with them and a group of army officers. He criticized them for the failures in dealing with Parliament. Signaling his turning back to the policy of "healing and settling," he told them "it is time to come to a settlement and lay aside arbitrary proceedings, so unacceptable to the nation." ${ }^{397}$ Some of the major-generals were crestfallen after their pet program—which must have seemed to them like the obvious and perhaps only effective defense against further rebellionhad been abandoned by their chief. But it had proven to be too ideologically unpopular. ${ }^{398}$ The experience of the Militia Bill's defeat had, in fact, further prompted the Protector to return to the policy of moderation, which was both his instinct and his inclination.

\footnotetext{
396 Durston, 214-5.

${ }^{397}$ Cromwell quoted in Durston, 221.

${ }^{398}$ Durston, 210-222; Little and Smith, 59-71.
} 
The major-generals initiative was begun with security of the nation in mind, and it ended with the security of Parliamentary privilege and the spirit of cooperation in mind. The initiative came to be because of concerns of foreign invasion and internal rebellion. And due to the inability of Parliament to function, the chief magistrate and Council had reasonably reacted to those threats based on the options available to them. Parliament could not or would not supply and support the government, so they sought other means. The militia which had risen against the Royalists had been the silver lining in Penruddock's rising, demonstrating a new source of armed defense. The government had turned to them as a source of security that was both adaptable to the conditions and traditional, as militias had been part of the system of country security for decades.

However, following the reaction in the localities, the difficulty in making the decimation system of financial support function in the face of considerable gentry and aristocratic opposition, and the willingness of Parliament to support Oliver Cromwell and work in a productive manner, there seemed little necessity for keeping the program alive. Finally Cromwell seemed to have gained a solid basis of support among moderates, and as militias and the tax that supported them were unlikely to work without significant, potentially rebellious opposition there was little reason to continue them. So Cromwell let his "little invention" go down to defeat, believing that security was to be found in tradition and consensus rather than innovation.

Opponents would further tar the major-generals and by association army-backed government, accusing them of tyranny. But the major-generals were not bad men. Rather, they were men tasked with doing some unpopular work in addition to tending to 
matters which had always previously been managed by the country gentry. The Civil Wars and ensuing revolution were not a class-based revolution. But the relatively low birth and social position of the major generals was an issue, either because it rankled the traditional elites that such "mechankal" inferiors should command them or because they thought such low-born persons incapable of acting in a gentlemanly fashion. Majorgeneral Goffe wrote to Thurloe in regards to the work of the decimations "the stresse must lie upon the middle sort of men." 399

During the parliamentary debates over the Militia Bill, Thomas Burton retired to an alehouse on January $8^{\text {th }}, 1657$ with several fellow members. Burton reports that they observed that Captain Philip Jones, who has now 70001. per annum, was born but to 8 or 101. a year, Sir John Barkstead was as thimble-maker, [Major-general] Kelsey sold leather-points, Major-General Bridge was a common dragooner in Yorkshire, not long since a sneaking, etc.; and they reckoned up the mean extractions of many more Major-Generals. ${ }^{400}$

The account given of their defects entailed not lack of capability or cruelty, but simply "meanness," in the seventeenth-century sense, that is, non-gentry status. To the gentrywhether they were Royalist or not—-the major-generals were working above their station and unwittingly threatened the bonds of deference on which the gentry based their positions and safety. The MPs and their class (or social order, if one prefers) were under attack from the Quakers, from the cottagers and vagabonds, and from the common "disorderly" rabble and they had little desire to submit themselves to "silly mean men," however much their efforts in the countryside might have been for security.

\footnotetext{
${ }^{399}$ TSP, 4:161

${ }^{400}$ Thomas Burton, Guibon Goddard, and John Towill Rutt. Diary of Thomas Burton (London: H. Colburn, 1828), 1:331.
} 
Cromwell was far more inclined to trust his plain russet-coated captains and saints who had "shed much blood" for the republic than those who had been born to their high positions. However, it is also true that Cromwell was no Leveler or advocate of Levelers, having put down rebelliously democratic risings in the army by cashiering or shooting its leaders if necessary. ${ }^{401}$ He spoke of the importance of that social order, "A nobleman, a gentleman, a yeoman; the distinction of these : that is the good interest of the nation." ${ }^{, 402}$ However, though he acknowledged it, he underestimated the gentry's power at the time. Cromwell and the Council saw the opportunity to support the militias with the tax on Royalists - who were after all the enemies of the well-affected gentry. But he had underestimated the cohesion of the gentry: violating the privileges and offending the dignity of some-Royalist or not—-threatened the privileges of the entire gentry order. Eventually Cromwell was persuaded to consider accepting the crown, but he refused. Had he taken it, perhaps adding "king" to the Cromwell name and putting his family officially at the top of the social order would have prevented a Stuart restoration. Yet acceptance could have also triggered revolts in the army and another Civil War, something Oliver desperately wanted to avoid. ${ }^{403}$ Alternatively, such a choice might have further split the loyalties of the nation, leading to a war between claimants to the crown rather than a fairly smooth restoration under Charles II. Nevertheless, the nation had supported its other Parliament-sanctioned monarchs, and it is certainly reasonable to believe that taking the crown might have led to the broad support that Cromwell sought after the tumultuous year of 1656. In early-modern England, rank trumped virtue, and in

\footnotetext{
${ }^{401}$ Worden, ECW, 94-5.

${ }^{402}$ Lomas, 2:342.

${ }^{403}$ Worden, ECW, 143-5.
} 
the late Commonwealth, the gentry "class" were more worried about threats to their power from below than from powers abroad. In the counties, the gentry had no place for decimators, Quakers, or Levelers. And they had no patience for major-generals, either. 


\section{Conclusion}

Some time after that you thought it was necessary to have Major-Generals, and the first rise to that motion then was the late general insurrections and was justifiable; and you Major-Generals did your parts well. You might have gone on. Who bid you go to the House with a bill and there receive a foil?...How you have failed therein, and how much the country hath been disobliged, is well known. ${ }^{404}$

Oliver Cromwell, Speech to the Army Officers, February 27, 1657

The period from 1655 to 1657 was a difficult one for the victors of the English Civil Wars; they were beset by enemies and misfortune from every side. Even their innovative attempt to deal with those enemies and solve a plethora of administrative problems, the major-generals' initiative, was turned against them and endangered the government's limited political consensus. This study has examined the planning of the major-generals initiative, how the plan was implemented, how the localities were affected, and how people in the localities reacted to the officers' presence and activities. The overall conclusion of this thesis is that the work of the major-generals was primarily for the purpose of increasing security and that despite their largely good-faith attempt to achieve their goals for the good of the nation, they achieved little while incurring the

\footnotetext{
${ }^{404}$ Oliver Cromwell, Speech to the Army Officers, February 27, 1657, as quoted in Lomas, 3:487-8.
} 
opposition of England's politically dominant class: the gentry. This reaction would turn the central government away from innovative, military-led initiatives and back toward more traditional approaches, particularly in the shires.

Additionally, this thesis has shown that though the Protector, the Council of State, and godly officers of the New Model Army made some effort to promote moral reformation while fulfilling their other duties, these measures were both limited and largely in keeping with the overall security- and order-oriented nature of the majorgenerals' work. Rather than constituting a new push toward religious reform of the localities, the program is more appropriately seen as an attempt to pursue political stability through the suppression of disorder, so that Englishmen could enjoy the "rights and liberties" that the "saints" of the New Model Army had won for them in ten years of nearly constant warfare.

Unfortunately, Parliament saw the program differently than did the Protector and other leaders of the government, and the Militia Bill, which would have given parliamentary sanction to the major-generals' efforts, was soundly defeated. Yet the supposed "tyrannical" or arbitrary tendencies of the major-generals and Cromwell's government were not the cause of that defeat. Instead, the major-generals were not able to gain support among the parliamentary class because the gentry did not believe that the advantages of the officers' presence and activities outweighed the abrogation of elite privileges that the extra-Parliamentary decimation tax represented. The major-generals may have promoted security and good order, but their methods of pursuing them were not acceptable to the hierarchical social order of seventeenth-century England. 
The major-generals and their assistants operated under the provisions of the "Commission for Securing the Peace of the Commonwealth," which was an appropriate title considering the work they did: increasing security and good order after years of intermittent military conflict and disorder. After a failed Royalist rising in March of 1655 which seemed to have had the potential for overthrowing the government or renewing Civil Wars, Whitehall had begun to take additional measures to ensure that subsequent plots would not threaten the nation, which the will of God had bestowed upon Oliver Cromwell and the "honest" godly men of England. While additional security measures were enacted at first in a piecemeal fashion, a few months after Penruddock's rising the major-generals' initiative was conceived with a dual purpose: to raise horse militias and pay for them by taxing high-status Royalists. The Council believed that the militias were a cost-effective measure necessary to prevent further risings, and government supporters strongly believed that the financial basis of the program was perfectly justified since it placed the financial burden of additional defense on those who had necessitated the raising of more troops. Levying a punitive tax was also seen as a measure which would discourage further support for rebellion.

As arrangements progressed, further responsibilities were assigned to those who were initially just to do the work of taxing Royalists and raising the new militias. The breadth of the additional tasks was remarkable, but most had in common the principle of making the nation safer from rebellion and eliminating what was felt to be a precondition of rebellion: disorder. A small number of those additional tasks were focused on 
effecting moral reform in the counties, but the great majority had increasing order and security of the counties as their primary purpose.

The job of seeing to these measures was assigned to army officers who were elevated to the rank of major-general. Considering the divisions between political factions still adhered to by many in the country and the uncertain loyalties of many in local administration — particularly after a rebellion which had started in the countrysidearmy men were a safe choice to do the work, particularly as it included raising and commanding troops. The major-generals came from a variety of backgrounds, but all were long-serving soldiers and were thus well-known in central government circles. Yet they were often not well-known in the localities where they worked, and some were not experienced in local administration or were not members of the gentry. Additionally, they were assisted by groups of commissioners who were also of varying social status and experience: some were of the "middling sort," others were army officers, and some were gentlemen, though usually not of the upper gentry.

When the major-generals arrived in their assigned countries, they began by setting up the horse militias, work which they found easy and natural. Taxing the Royalists, on the other hand, they found daunting. Nevertheless their efforts met with less open resistance than some of the officers had feared, and collecting the tax went reasonably well, even though the officers found themselves administratively unprepared for the work. The major-generals also found that they needed assistance and guidance regarding basic details of implementing the tax, such as which persons should be taxed, further demonstrating their own inexperience in administrative matters and the limited 
forethought of those at Whitehall who had conceived the tax. Also, the officers were required to deal with those who were traditionally above their station-JPs and town councilmen -in situations which were ripe for giving offense or making missteps which could easily belie the generally well-intentioned purpose of the major-generals' actions. The officers had been instructed to keep in mind the effect on local people as they went about their work, and they were very clearly supported by a significant portion of the populace in their efforts. But some of the officers were not especially deferential or respectful when dealing with the Royalists. The upper gentry and peers resented being taxed and bound to good behavior by those - the commissioners and major-generalswho they might reasonably have expected to defer to them.

In addition to the primary objectives of taxation and militias, the officers also had the remit of seeing to the implementation of a variety of other policies. Over the centuries historians have often propagated the commonplace that the implementation of those policies, which could be seen as oppressive, arbitrary, or puritanical in nature, was a major factor in turning the populace against the government. Gauging the nature and impact of these measures is a difficult task, especially considering the biased perspective of the many Restoration-era diarists who reported them. But since the major-generals' enforcement activities concerned matters of social order, court and administrative records of the time were consulted to see how such enforcement activities impacted the communities, particularly since the officers were directed to work with traditional local office holders—JPs, sheriffs, bailiffs, constables—-to effect greater order in the counties. Previously, maintaining order—known as "keeping the peace"—and implementing 
government policy in the shires had been the exclusive right of local authorities who considered such power to be their right and privilege as members of the gentry. For those traditionally entrusted with those duties and offices, the appointment of outsiders and lower-status assistants to do this work would have been resented: another example of the "world turned upside down" in the period, in which social inferiors ruled their superiors.

The county of Essex has been the local focus of this study, with the records of the county quarter sessions being an important source in addition to the bi-yearly assize circuit and the quarter and petty sessions of Maldon, a small corporate port town in the county. In contrast to some previous studies of order infractions - or crimes-which focused solely on indictments, the analysis presented here focused on all available judicial proceedings. The advantage of this approach is that less serious but still important offences regarding order, which are often under-represented in indictments, become available for study. Additionally, minor matters regarding social order were also dealt with on the level of petty sessions held by one or two justices and resolved by means of judgments predicated on the cooperation of the accused. Those cases are generally only listed in passing at the quarter sessions and were usually not subject to indictment and jury trial, but they have been used here to provide further information of those low-level offenses.

This study has concentrated on the anecdotal reading and analysis of the sources, often producing a much more informative picture of the priorities and practices of those who dealt with justice and order than does a mere counting of cases. Therefore, while some tabulation of enforcement efforts has been included, along with quantitative 
information assembled by other social historians, the assessment of the impact of the major-generals have been based predominantly on qualitative analysis.

Recently, historians have argued that one of the primary aims of the majorgenerals' work was moral reform. The traditional judicial work of maintaining the peace, however, was closely related to that of moral reform. Thus it is incorrect to assume that enforcement of the statutes against matters as illegal alehouses, vagabonds, bastardy, Sabbath-breaking, and the like was only—or even primarily—undertaken with strictly moral aims in mind, because the same offenses were thought to undermine social order and tranquility. Whether because of a desire to impose godliness or simply to keep the "common peace," matters touching both morality and social order were of consistent concern to the Essex JPs even before the work of the major-generals began.

Justices used a variety of measures to keep the peace in the communities and reform offenders in ways appropriate to the crime and the offender's character rather that strict adherence to a legal standard. This practice did not start in the Interregnum, and justices in the late sixteenth and early seventeenth centuries had generally always dealt with violations of order-particularly minor ones—in this way. Compared to previous decades though, there seem to have been some differences in the mid-1650s. Sexual trespasses were dealt with on a more statutory basis, and with less flexibility, than during the pre-Civil War period. However, this study has revealed that however harsh the Commonwealth statutes were, the discretion and priorities of justices has significant impact on judicial outcomes and the application of moral penalties. This manner of dealing with many types of cases seems not to have been significantly changed by the 
presence of the major-generals, which indicates that the stricter application of such purely moral statutes was not of great concern to the officers. This is difficult to say with certainty, though, because social order and morality were generally considered to be closely linked. In any case, the justices had been deeply involved in the administration of such matters long before the major-generals arrived, and their judgments do not seem to have been significantly affected by those "outsiders."

The overall picture that emerges from the examination of court records is that in their pursuit of greater morality and orderliness, the major-generals were not especially disruptive, and any positive impact they had on improving order among the common sort was probably appreciated by the gentlemanly class. It also seems unlikely that the officers did much terrorizing of the populace with their supposed suppression of sinful behavior. Instead, the major-generals who supervised the county was far more concerned with the potential of either another Royalist rising coming via public gatherings or meetings such as judicial sessions, or the government's opponents gaining political ascendancy. In the latter case their fears were reasonable, although it was not the supposed moral reformation but the extra-parliamentary tax that caused the government's electoral and political headaches. The decimations united several politically fragmented groups into a faction which effectively opposed the government in the elections and Parliament in 1656. The opposition faction had a limited lifespan, and in terms of effectiveness it largely dissolved once the Militia Bill, which would have given Parliamentary approval for the tax, had been defeated and moderates had offered Cromwell the crown. The anti-government momentum thus subsided, but the memory of 
its effectiveness against the army was not forgotten. For the army officers, however, whatever hopes they had of putting their commissions, horse militias, and taxation scheme on a permanent footing were lost and their disappointment was palpable. Though in Sussex Major-general William Goffe had been elected to Parliament in the contested elections of 1656 , he reported that the returns were much to "the griefe of the honest party."405

The major-generals were forced to drink from a bitter cup, for Parliament subsequently voted the decimation tax and thus the major-generals work in the localities out of existence. Cromwell as well expressed his opprobrium for the major-generals' efforts shortly after the Militia Bill's defeat and partially as a result, lost faith in new reforms to improve order, instead deciding to return to the previous policy of reconciliation with the traditional elite. ${ }^{406}$ "It is time to come to a settlement," Oliver told the major-generals, "and lay aside proceedings, so unacceptable to the nation." 407

It is fair to say that the major-generals did earn themselves quite a bad name, though rather unjustly. They were officers of a standing army, something always unpopular in England. Ironically, within two decades a standing army would become necessary to secure England's place as a significant player in the European power game-a process which had begun in earnest under Oliver Cromwell with the backing of the New Model Army, from which the major-generals had been picked. Further research on the major-generals might note any precedents the major-generals set in regard to army interference in civilian governance. Also, some of the policies the officers helped to

\footnotetext{
${ }^{405}$ TSP, 5:341.

${ }^{406}$ Underdown, "Settlement in the Counties," 172-179.

${ }^{407}$ Lomas, 3:488.
} 
enforce would become staples of future governments, such as transportation to the colonies, and tracing such policies could reveal previously unknown influences by the major-generals on posterity. According to many government opponents, the "rule" of the major-generals was "nasty, brutish, and short," though they were definitely engaged in preventing a war of "all against all." The major-generals initiative was an important policy experiment in Hobbes' "highest time," and it would be interesting to trace what effect it had on political thinking — or what effect political thinking had on the creation of their offices.

There are many aspects of their tenure that have gone unexplored, which seems unfortunate because the failure of a government initiative can often indicate more about a period than its successes. Another area of interest would be to note the interactions with and reactions to the major-generals by those of the middling social strata or "meaner sort," particularly the grand juries which Haynes was so keen to keep an eye on in March of 1655. Particularly since many of the commissioners around the country came from similar backgrounds one wonders whether they had support from or were disliked by that demographic. A topic of interest regarding the major-generals and crime records would be to analyze whether there were consistent changes in the sentences offenders received in the period. This would be of particular interest in Essex because harsher penalties might have stirred additional resistance in the elections, and could thus have generated some of the accusations of tyranny that followed the officers through the ensuing centuries. Also, the close connection between the JPs and major-generals in Essex was 
unusual, and it would be interesting to discover the extent to which that arrangement perhaps increased resentment between the JPs and other gentry.

The major-generals' immediate impact on policy was that the government of Oliver Cromwell would subsequently avoid policies which might further alienate the gentry and remaining peerage by treading on their privileges. Actually, the dispute between the government and the localities which the major-generals represented was a peculiar one because they were fighting for different versions of the same basic principle: defending the rights and liberties of Englishmen. The government sought better security to defend the nation against the re-imposition of an absolutist-leaning Stuart monarchy which had attempted to govern against the will of its subjects, imposing taxation, religion, and policy without the parliamentary approval. The gentry in the localities resisted the major-generals because, like Charles I, the officers had imposed a tax on part of the gentry which Parliament had not approved: once again central government had taken upon itself the power to levy taxes, a right which had long been the province of Parliament.

The miscalculation of Cromwell and his Council—and the army officers, as was evidenced in the Protector's speech to them—was that they had tried to secure rights and liberties while simultaneously threatening those of the gentry class which saw themselves as having common interests. ${ }^{408}$ Freedom from unapproved taxation and central government intrusion were some of the "rights" that the gentry had come to the Long Parliament in 1640 and fought a Civil War to protect, and those were the rights they were

\footnotetext{
${ }^{408}$ Fletcher, "Oliver Cromwell and the Localities," 137.
} 
protecting when they voted down the Militia Bill in 1657. The Civil Wars may have been fought for God and church, but the major-generals were fought to protect privilege.

Oliver Cromwell was wise—or well-advised—enough to see that opposing Parliament and the gentry's will would only result in greater instability, which meant the possibly of more bloodshed. So he gave up the very well-intentioned efforts to work through the major-generals and returned to the policy of "healing and settling," which meant keeping the army out of the gentry's way and attempting to work through the traditional governmental structures in the localities and—where possible—Parliament. But the working consensus broke down after Oliver Cromwell's death, and when his son, Richard, moved too close to the moderates who held the power in the localities, the army responded by abolishing the Protectorate.

This Pyrrhic victory would soon prove the army's undoing. In 1659-60, the antiarmy gentry coalition which had opposed the major-generals and their tax re-coalesced. That coalition stood for continuance of the gentry's power, rights, and privileges against opponents from above and from below, including Anabaptists, Fifth Monarchists, Levelers, army radicals, and Quakers, all of whom threatened gentry power by contesting the social hierarchy. Charles II and monarchy stood for traditional order, so when he promised to rule the gentry's way they invited him back. ${ }^{409}$ They supported the Restoration for the same reasons they had opposed Cromwell's major-generals who had supposedly come to protect them from the Royalist threat.

Cromwell learned from his "little invention" just how powerful the gentry had become. Subsequently, Charles II respected that power and ruled for twenty five years.

${ }^{409}$ Woolrych, “Last Quests for Settlement,” 199-202. 
James II would again try to contest that power, leading to his ouster via the Glorious—or perhaps gentry—Revolution of 1688. A century and more before the Civil War period, kings and Lords had ruled England. Eventually, democratic government in collaboration with the monarchy would rise to the fore. But the seventeenth century was the time of the gentry—and woe to major-generals or monarchs who tried to contest their control. 


\section{Works Cited}

\section{Primary Sources}

Allen, D. H. Essex Quarter Sessions Order Book, 1652-1661. The Essex County Council, 1974.

Bossuet, Jacques Benigne. "Funeral Discourse Upon Henrietta Maria, Queen of Great Britain.” In Panegyrics of the Saints. Edited by D. O'Mahoney. London: Kegan Paul, Trench, Trubner and Co., 1924.

Burton, Thomas, Guibon Goddard. Diary of Thomas Burton. Edited by John Towill Rutt. Vol. 3. London: H. Colburn, 1828.

Cliffe, J. T., ed. "The Cromwellian Decimation Tax of 1655. The Assessment Lists." Seventeenth-Century Political and Financial Papers. Edited by D. R. Ransome. London: Cambridge University Press, 1996.

Cromwell, Oliver and Thomas Carlyle. The Letters and Speeches of Oliver Cromwell. Edited by S. C. Lomas. 3 vols. London: Methuen \& Co, 1904.

Cromwell, Oliver. The Writings and Speeches of Oliver Cromwell. Edited by Wilbur Cortez Abbott. Vol. 4. London: Oxford University Press, 1947.

Dalton, Michael. The Countrey Justice, containing the practice of the justices of the peace out of their sessions. London, 1655. Wing D144.

A Declaration of his Highness...for Securing the Peace of the Commonwealth. London, 1655. Wing C7082.

Essex Record Office. Maldon Sessions Book, 1631-1664. D/B 3/1/20.

Essex Record Office. Quarter Sessions Rolls, Q/SR 264-386. Seax: Essex Archives Online.

Firth, C. H. and Robert S. Rait, eds. Acts and Ordinances of the Interregnum, 16421660. London: HMSO, 1911.

At the general Quarter-session of the publick Peace of the County of Hertford. Hertfordshire, 1655. Thomason H1602B. 
Green, Mary Anne Everett, ed. Calendars of State Papers, Domestic Series, 1649-1660. 13 vols. London: Longmans, 1881.

Hutchinson, Lucy. Memoirs of the Life of Colonel Hutchinson. London: Oxford University Press, 1973.

Josselin, Ralph and Alan Macfarlane. The Diary of Ralph Josselin, 1616-1683. London: Oxford University Press, 1976.

King Charls his speech made upon the scaffold at Whitehall-Gate. London, 1649. Wing C2792.

Ludlow, Edmund. Memoirs of Edmund Ludlow, Esq. Edited by C.H. Firth. Vol. 2. Oxford: Clarendon, 1894.

O'Farrell, N. McNeil, ed. Calendar of Essex Assize Files in the Public Record Office. Vol. 4.

Parnel, James. The trumpet of the Lord blowne. Or, a blast against pride and oppression, and the defiled liberty, which stands in the flesh. London, 1655.

Petition and Desires of all the loyall and true-hearted...of the County of Essex. London, 1648.

Robespierre, Maximilien. "Report on the Principles of Political Morality (5 February 1794)." In The Old Regime and the French Revolution. Edited by John W. Boyer, Julius Kirshner and Keith Michael Baker. Vol. 7 of University of Chicago Readings in Western Civilization. University of Chicago Press, 1987.

Thurloe, John. A Collection of the State Papers of John Thurloe. Edited by Thomas Birch. 7 vols. London: printed for the executor of the late Mr. Fletcher Gyles; Thomas Woodward; and Charles Davis, 1742.

\section{Secondary Sources}

Aylmer, G. E. The Interregnum: The Quest for Settlement, 1646-1660. London: Macmillan, 1972.

Ashley, Maurice. The Greatness of Oliver Cromwell. New York: Macmillan, 1958.

Aubrey, Philip. Mr. Secretary Thurloe: Cromwell's Secretary of State, 1652-1660. London: Athlone Press, 1990. 
Brewer, John and John A. Styles, eds. An Ungovernable People: The English and Their Law in the Seventeenth and Eighteenth Centuries. London: Hutchinson, 1980.

Coward, Barry. The Cromwellian Protectorate. Manchester: Manchester University Press, 2002.

Cockburn, J. S. Crime in England, 1550-1800. Princeton: Princeton University Press, 1977. 1972.

. A History of English Assizes, 1558-1714. Cambridge: University Press,

Davies, Godfrey and C. H. Firth. The Regimental History of Cromwell's Army. 2 Vols. Oxford: Clarendon Press, 1940.

Durston, Christopher. Cromwell's Major Generals: Godly Government During the English Revolution. Manchester: Manchester University Press, 2001.

Durston, Christopher and Judith D. Maltby. Religion in Revolutionary England. Manchester: Manchester University Press, 2006.

Firth, C.H. and Samuel Rawson Gardiner. The Last Years of the Protectorate, 1656-1658. 2 vols. New York: Russell \& Russell, 1964.

Fletcher, Anthony. Reform in the Provinces: The Government of Stuart England. New Haven, CT: Yale University Press, 1986.

Sussex 1600-1660: A County Community in Peace and War. Chichester, Sussex: Phillimore, 1980.

Fletcher, Anthony and John Stevenson, eds. Order and Disorder in Early Modern England. Cambridge: Cambridge University Press, 1985.

Gardiner, S. R. History of the Commonwealth and Protectorate, 1649-1656. 4 vols. New York: AMS Press, 1965.

Goubert, Pierre. Louis XIV and Twenty Million Frenchmen. New York: Vintage Books, 1972.

Grieve, Hilda E. P. The Sleepers and the Shadows: Chelmsford, a Town--Its People and Its Past. 2 vols. Chelmsford: Published by the Essex County Council in association with the Chelmsford Borough Council, 1988. 
Guizon, Francios. The Life of Oliver Cromwell. London: Macmillan, 1899.

Herrup, Cynthia B. The Common Peace: Participation and the Criminal Law in Seventeenth-Century England. Cambridge: Cambridge University Press, 1987.

Hill, Christopher, D. H. Pennington, and Keith Thomas, eds. Puritans and Revolutionaries: Essays in Seventeenth-Century History Presented to Christopher Hill. Oxford: Clarendon Press, 1978.

Hill, Christopher. Religion and politics in 17th century England, vol. 2 of The Collected Essays of Christopher Hill. Amherst, MA: University of Massachusetts Press, 1985.

Hirst, Derek. England in Conflict, 1603-1660: Kingdom, Community, Commonwealth. London: Arnold, 1999.

Hobbes, Thomas. The English works of Thomas Hobbes. Vol. 6. Edited by M. Molesworth. London: J. Bohn, 1839-1845.

Hughes, Ann. Politics, Society, and Civil War in Warwickshire, 1620-1660. Cambridge: Cambridge University Press, 1987.

Hunt, William. The Puritan Moment: The Coming of Revolution in an English County. Cambridge, MA: Harvard University Press, 1983.

Ives, E. W. The English Revolution, 1600-1660. New York: Barnes \& Noble, 1969.

Kishlansky, Mark. A Monarchy Transformed: Britain 1603-1714. London: Penguin, 1996.

Laslett, Peter, Karla Oosterveen, and Richard Michael Smith. Bastardy and Its Comparative History: Studies in the History of Illegitimacy and Marital Nonconformism in Britain, France, Germany, Sweden, North America, Jamaica, and Japan. Cambridge, MA: Harvard University Press, 1980.

Little, Patrick and David L. Smith. Parliaments and Politics During the Cromwellian Protectorate. Cambridge: Cambridge University Press, 2007.

Martin, Ingram. Church Courts, Sex, and Marriage in England, 1570-1640. Cambridge: Cambridge University Press, 1987.

Morrill, J. S. Cheshire 1630-1660: County Government and Society During the English Revolution. London: Oxford University Press, 1974. 
. The Nature of the English Revolution: Essays. London: Longman, 1993.

. "Religious Context of the English Civil War." Transactions of the Royal Historical Society. Fifth Series, vol. 34 (1984): 155-178.

. The Revolt of the Provinces: Conservatives and Radicals in the English Civil War, 1630-1650. London: Longman, 1987.

. Revolution and Restoration: England in the 1650s. London: Collins \& Brown, 1992.

Morrill, J. S. and J. S. A. Adamson. Oliver Cromwell and the English Revolution. London: Longman, 1990.

Nuttall, W. L. F. "Hezekiah Haynes: Oliver Cromwell's Major-General for the Eastern Counties." Transactions of the Essex Archaeological Society. Vol.1, pt.3 (1964): 197-198.

Oxford English Dictionary Online. Oxford University Press, March 2012.

Oxford Dictionary of National Biography. Edited by H. C. G. Matthew and Brian Harrison eds. Oxford: OUP, 2004. Online edn. Edited by Lawrence Goldman, January 2008.

Quintrell, B. W. The Government of the County of Essex, 1603-1642. Unpublished PhD Thesis, University of London, 1965.

Rannie, David Watson. "Cromwell's Major-Generals." English Historical Review 39 (July 1895): 471-506.

Reay, Barry. "Quaker Opposition to Tithes 1652-1660." Past and Present 86 (February 1980): 98-120.

Round, J. H. "Colchester During the Commonwealth." English Historical Review 15 (October 1900): 641-664.

Sharpe, J. A. Crime in Seventeenth-Century England: A County Study. Cambridge: Cambridge University Press, 1983.

Smith, David L., ed. Cromwell and the Interregnum: The Essential Readings. Malden, MA: Blackwell Pub, 2003.

Smith, David L. The Stuart Parliaments, 1603-1689. London: Arnold, 1999. 
Underdown, David. Revel, Riot, and Rebellion: Popular Politics and Culture in England, 1603-1660. Oxford: Clarendon Press, 1985.

. Royalist Conspiracy in England, 1649-1660. Hamden, CT: Archon Books, 1971.

Somerset in the Civil War and Interregnum. Newton Abbot [UK]: David \& Charles, 1973.

Watt, Tessa. Cheap Print and Popular Piety, 1550-1640. Cambridge: Cambridge University Press, 1991.

Worden, Blair. The English Civil Wars, 1640-1660. London: Weidenfeld \& Nicolson, 2009.

The Rump Parliament, 1648-1653. Cambridge: Cambridge University Press, 1974.

Woolrych, Austin. Britain in Revolution, 1625-1660. Oxford: Oxford University Press, 2002

. Commonwealth to Protectorate. Oxford: Clarendon Press, 1982.

Wrightson, K. E. The Puritan Reformation of Manners With Special Reference to the Counties of Lancashire and Essex, 1640-1660. Unpublished PhD thesis, Cambridge, 1973. 